UNIVERSIDADE DE SÃO PAULO

ESCOLA POLITÉCNICA

DANIEL DE FREITAS KERSTING

Reciclagem de aparas de pás eólicas para a produção de elementos filtrantes para tratamento de água

São Paulo

2019 


\section{Reciclagem de Aparas de Pás Eólicas para Produção de Elementos Filtrantes para Tratamento de Água}

\section{Versão Corrigida}

Tese apresentada ao Departamento de Engenharia Metalúrgica e de Materiais da Escola Politécnica da Universidade de São Paulo para obtenção de título de Doutor em Ciências.

Área de Concentração: Engenharia Metalúrgica e de Materiais

Orientador: Prof. Dr. Hélio Wiebeck

Co-orientador: Prof. Dr. Sandro D. Mancini

São Paulo 
Autorizo a reprodução e divulgação total ou parcial deste trabalho, por qualquer meio convencional ou eletrônico, para fins de estudo e pesquisa, desde que citada a fonte.

\section{Este exemplar foi revisado e alterado em relação à versão original, sob responsabilidade única do autor e com a anuência de seu orientador.}

São Paulo, 27 de janeiro de 2020

Assinatura do autor:

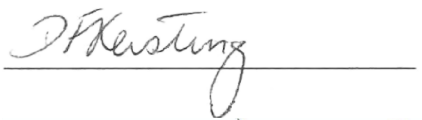

Assinatura do orientador:

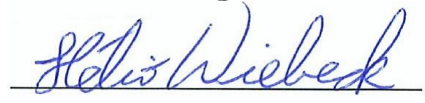

\section{Catalogaçāo-na-publicação}

Kersting, Daniel de Freitas Kersting

Reciclagem de Aparas de Pás Eólicas para Produçăo de Elementos

Filtrantes para Tratamento de Água / D. F. K. Kersting --versão corr. - São

Paulo, 2019.

$122 \mathrm{p}$.

Tese (Doutorado) - Escola Politécnica da Universidade de São Paulo.

Departamento de Engenharia Metalúrgica e de Materiais.

1.reciclagem 2.aquecimento por micro-ondas 3 filtraçăo e adsorçăo 4.tratamento de água I.Universidade de Săo Paulo. Escola Politécnica.

Departamento de Engenharia Metalúrgica e de Materiais II.t. 
Dedico este trabalho a todos, que em sua rotina, continuam sempre perseverando sem esmorecer, com regularidade e constância, $e$ que acreditam que no final, sempre vale a pena! 


\section{AGRADECIMENTOS}

À Deus, por ter me dado a graça desta existência e me permitir aprender muito com tudo e com todos.

Ao meu orientador Prof. Dr. Hélio Wiebeck, do Departamento de Engenharia Metalúrgica e de Materiais, da Escola Politécnica (PMT-USP), pelo incentivo, colaboração e confiança depositada em todas as etapas do trabalho, e que com seu bom humor e paciência me acompanhou nesta jornada desde 2012, com início dos estudos em pós-graduação (mestrado) no PMT.

À banca composta pela Prof ${ }^{a}$ Dra. Priscila Anadão, pelo Prof. Dr. Fábio José Esper, Prof. Dr. Leonardo Gondim de Andrade e Silva, e pelo Prof. Dr. Derval dos Santos Rosa, que com suas sábias colocações permitiram este trabalho ficar melhor ainda. Ao Prof. Dr. Sandro Donnini Mancini, pelo espaço cedido no NATEL/UNESP para início dos trabalhos, sem o qual este trabalho teria maior dificuldade para começar. Aos meus colegas, técnicos e engenheiros do Centro Industrial Nuclear de Aramar (CINA), pelo apoio crucial no encerramento deste trabalho: Carlos Alberto Martins Rezende, Renato de Conti, Eduardo Pereira Luiz, Paulo Sérgio, Carlos Nunes, Genson Machado, Tatiani Silva, João Jorge, Camila Souza, e especialmente a Fernanda da Silva Porcel.

Às pesquisadoras do IPT Dra. Ana Carolina de Souza Miranda Teixeira e Dra. Luciana Galvão, que deram sensível contribuição aos resultados finais obtidos.

Aos meus sogros Vanderlei e Sueli Porcel, pelo espaço cedido para continuidade das pesquisas em laboratório próprio, em casa.

Aos meus pais, Ruben e Maria Beatriz, pela oportunidade desta existência.

A minha dedicada e amorosa esposa Fernanda, eternamente paciente, e meus amores, Ariane e Isadora: sem vocês por perto terminar este trabalho teria sido muito mais difícil, amo todas vocês.

À FAPESP e ao PMT-USP, pelo aporte financeiro das pesquisas. 
"Peçam, e Ihes será dado; busquem, e encontrarão; batam, e a porta lhes será aberta. Pois todo o que pede, recebe; o que busca, encontra; e àquele que bate, a porta será aberta.

Qual de vocês, se seu filho pedir pão, Ihe dará uma pedra? Ou se pedir peixe, Ihe dará uma cobra? Se vocês, apesar de serem maus, sabem dar boas coisas aos seus filhos, quanto mais o Pai de vocês, que está nos céus, dará coisas boas aos que Ihe pedirem!" 


\section{RESUMO}

KERSTING, D. F. Reciclagem de Aparas de Pás Eólicas para Produção de Elementos Filtrantes para Tratamento de Água. 2019. 121 folhas. Tese de Doutorado - Escola Politécnica, Universidade de São Paulo, São Paulo - 2019

A abordagem adotada neste trabalho parte de uma visão diferente: o uso de resíduos de materiais compósitos em aplicação de engenharia distinta de sua utilização original. Esta nova abordagem trata de usar resíduos de materiais compósitos para a aplicação em novos produtos, diferentes do existente na área de compósitos, e que possam, de fato, ter um novo ciclo de vida de utilização, em uma nova aplicação de engenharia. Com foco nesta abordagem, foram estudados os resíduos de aparas de pás eólicas, recebidos na forma de pó composto de partículas de fibra de vidro e pó de resina epóxi curada, na proporção de $64 \%$ de fibra de vidro e $36 \%$ de resina epóxi. A similaridade do resíduo com a areia empregada em estações de tratamento de água conduziu aos primeiros testes em laboratório para uso como elemento filtrante para água. Nos primeiros ensaios, para avaliação de uso como pré-filtro para tratamento de água, o elemento filtrante à base de resíduo de fibra de vidro/resina epóxi reduziu drasticamente a turbidez da água. Por outro lado, a existência de uma fase orgânica composta de resina epóxi curada, direcionou os trabalhos para buscar 0 processamento do material para tratar esta fase orgânica. Para este processamento foi escolhida a irradiação por micro-ondas, com a presença de absorvedores de energia. Buscando agregar mais propriedades ao novo elemento filtrante, foram escolhidos absorvedores químicos (carvão ativado, alumina ativada e zeólitas), como absorvedores de energia. Os resultados obtidos credenciam a aplicação do resíduo de fibra de vidro/resina epóxi como um bom elemento filtrante primário, para uso como pré-filtro, reduzindo a turbidez de águas com alto teor de partículas sólidas em suspensão, entre outras características necessárias para tratamento inicial de águas residuárias $\left(\mathrm{pH}\right.$, Teor de $\mathrm{O}_{2}$, etc).

Palavras-chave: filtração, reciclagem, compósitos estruturais, fibra de vidro, microondas. 


\begin{abstract}
KERSTING, D. F. Recycling Wind Scrub Shavings for the Production of Filtration Elements for Water Treatment. 2019. 121 sheets. PhD Thesis - Polytechnic School, University of São Paulo, São Paulo - 2019

The approach taken in this paper is based on a different view: the use of composite material waste in engineering application different from its original use. This new approach is about using composite waste materials for application in new products, different from the existing ones in the composites area, which may actually have a new life cycle in a new engineering application. With a focus on this approach, wind blade waste residues, received in the form of fiberglass particulate powder and cured epoxy resin powder, in the proportion of $64 \%$ fiberglass and $36 \%$ epoxy resin, were studied. The similarity of the residue to the sand employed in water treatment plants led to the first laboratory tests for use as a water filter element. In the first trials, for evaluation of use as a water treatment prefilter, the fiberglass / epoxy resin-based filter element dramatically reduced water turbidity. On the other hand, the existence of an organic phase composed of cured epoxy resin, directed the work to seek the processing of the material to treat this organic phase. For this processing microwave irradiation was chosen, with the presence of energy absorbers. In order to add more properties to the new filter element, chemical absorbers (activated carbon, activated alumina and zeolites) were chosen as energy absorbers. The obtained results suggest the application of the fiberglass / epoxy resin residue as a good primary filter element for use as a prefilter, reducing turbidity of water with high suspended solid particle content, among other characteristics necessary for initial treatment wastewater $(\mathrm{pH}, \mathrm{O} 2$ content, etc.).
\end{abstract}

Keywords: filtration, recycling, structural composites, glass fiber, microwaves 


\section{LISTA DE FIGURAS}

Figura 1 - Esquema com etapas necessárias para reciclagem, e outras alternativas de destinação existentes (aterro sanitário, compostagem e incineração) .

Figura 2 - Sistema de reciclagem para materiais compósitos

Figura 3 - Fluxo do processo de reciclagem mecânica realizado pela ERCOM e Phoenix Fiberglass.

Figura 4 - Processo de extração via fluidos supercríticos para reciclagem de compósitos

Figura 5 - Fluxograma de processo de reciclagem via pirólise. 22

Figura 6 - Processo de reciclagem da ATI para tratamento de resíduos. 24

Figura 7 - Esquema de processo de solvólise para reciclagem de materiais compósitos

Figura 8 - Processo de reciclagem com irradiação via micro-ondas .27

Figura 9 - Irradiação por Micro-ondas de Solução para Degradação de Resina Epóxi

Figura 10 - Esquema simplificado de Reciclagem Térmica com reaproveitamento de fibras.

Figura 11 - Processo de reciclagem térmica estudado pela Universidade de Nottingham

Figura 12 - Processo de reciclagem de compósitos a base de fibra de vidro Compocycle.

Figura 13 - Comparação entre os diferentes tipos de materiais: transparente, opaco, absorvedores (naturais e com materiais absorvedores adicionados).

Figura 14 - Fator de perda dielétrica X energia absorvida por volume para alguns tipos de materiais.

Figura 15 - Componentes de um sistema de filtração típico, usado em laboratório .40

Figura 16 - Mecanismos de filtração: a) filtro de torta (fluxo perpenticular), b) filtro clarificador (fluxo perpenticular), e c) filtro de fluxo transversal.

Figura 17 - Detalhe da estrutura de poros de um adsorvente

Figura 18 - Calibração de potência irradiada pelos fornos de micro-ondas 58

Figura 19 - Termoimagem em Infravermelho de prato de vidro refratário aquecido por 
1 minuto em forno de micro-ondas comercial, com potência mediana: ponto quente marcado com $45,6 \stackrel{\circ}{\circ}$.

Figura 20 - Termoimagens em infravermelho do prato refratário do forno 25L, com $400 \mathrm{~g}$, aquecido por 1 minuto, no nível de potência 100: antes (esquerda), e após aquecimento (direita)

Figura 21 - Imagens obtidas via microscopia ótica: no alto a esquerda 5X, no alto a direita 10X, e logo abaixo 20X de aumento.

Figura 22 - Comparação entre o filtrado obtido a partir do uso do resíduo como elemento filtrante (ao centro), com água destilada (à esquerda), e com água-teste (à direita).

Figura 23 - Espectros de FTIR do extrato rico obtido do resíduo (acima), e água destilada (abaixo).

Figura 24 - Gráficos com variação de temperaturas obtidas para a zeólita e alumina ativ. (acima), e carvão ativado (abaixo) após aquecimento. por 1 minuto, em níveis de potência de 10 a 100 , no forno $25 \mathrm{~L}$

Figura 25 - Foto do ensaio de carbonização da mistura resíduo e carvão ativado, ao final do ensaio de 20 minutos, no nível de potência máximo do forno $28 \mathrm{~L}$.

Figura 26 - Gráfico perda de massa (\%) versus tempo, para teste com forno $25 \mathrm{~L}$..69

Figura 27 - Preparação do elemento filtrante para teste de capacidade de filtração do resíduo processado via irradiação de micro-ondas (esquerda), e filtrado obtido após a filtração com elemento filtrante produzido a partir do resíduo processado com carvão ativado (direita).

Figura 28 - Imagens obtidas via microscopia ótica: no alto a esquerda $5 \mathrm{X}$, no alto a direita 10X, e logo abaixo a esquerda 20X, e abaixo a direita 50X de aumento. ......72

Figura 29 - Análise termogravimétrica para amostra de resíduo tratada por mufla a gás.

Figura 30 - Termoimagem em infravermelho de cadinho refratário (esquerda), e condição após ensaio de irradiação com micro-ondas por 10 minutos, com resíduo e carvão ativado (proporção de 10/3,6) (direita).

Figura 31 - Imagens das fibras após o tratamento realizado pelo tempo de 2 minutos de irradiação obtidas via microscopia ótica: esquerda 5X, direita 10X, de aumento. 76

Figura 32 - Imagens das fibras após o tratamento realizado pelo tempo de 5 minutos de irradiação obtidas via microscopia ótica: no alto a esquerda $5 X$, no alto a direita 10X, e logo abaixo 20X de aumento .77

Figura 33 - Imagens das fibras após o tratamento realizado pelo tempo de 10 minutos de irradiação obtidas via microscopia ótica: a esquerda 5X, a direita 10X, de aumento 
Figura 34- Imagem das fibras após a fusão de filamentos de fibra de vidro para tempo de processamento de 5 minutos: imagens obtidas via microscopia ótica, a esquerda $5 \mathrm{X}$, e a direita 10X, de aumento.

Figura 35 - Imagem das fibras após a fusão de filamentos de fibra de vidro para tempo de processamento de 10 minutos: imagens obtidas via microscopia ótica, a esquerda $5 \mathrm{X}$, e a direita 10X, de aumento .79

Figura 36 - Imagens das fibras após a fusão de filamentos de fibra de vidro para tempo de processamento de 10 minutos obtidas via microscopia ótica: no alto a esquerda $5 \mathrm{X}$, no alto a direita 10X, e logo abaixo a esquerda 20X, e abaixo a direita 50X de aumento.

Figura 37 - Análise termogravimétrica para amostra de resíduo tratada com carvão ativado via irradiação de micro-ondas pelo tempo de 10 minutos. .80

Figura 38 - Resumo da classificação de águas doces, conforme normativa em vigor 103 


\section{LISTA DE TABELAS}

Tabela 1 - Resultados obtidos para reciclagem de compósitos via extração com fluidos supercríticos

Tabela 2 - Concentração de produtos obtidos após processo de pirólise 22

Tabela 3 - Concentração das frações de produtos obtidos via pirólise, para tipos de compósitos

Tabela 4 - Espectro eletromagnético ...............................................................

Tabela 5 - Bandas de frequência.................................................................

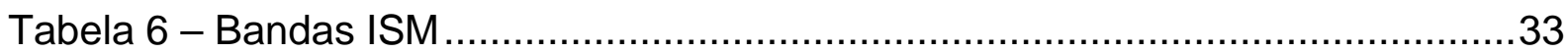

Tabela 7 - Variação de massa antes e após o processamento apenas com o resíduo

Tabela 8 - Variação de massa antes e após o processamento apenas com o carvão ativado.......

Tabela 9 - Variação de massa antes e após o processamento com mistura de resíduo/carvão ativado

Tabela 10 - Avaliação comparativa entre água-teste e filtrado obtido .......................70

Tabela 11 - Medidas de turbidez para os elementos filtrantes testados...................82

Tabela 12 - Medidas de $\mathrm{pH}$ para os elementos filtrantes testados .84

Tabela 13 - Medidas de cor $(\mathrm{uH})$ e teor de ferro $(\mathrm{ppm})$ para os elementos filtrantes testados.

Tabela 14 - Medidas de dureza total (ppm), e \% de redução com o uso dos elementos filtrantes.

Tabela 15 - Medidas de alcalinidade total (ppm) para os elementos filtrantes testados.

Tabela 16 - Medidas de condutividade $(\mu \mathrm{S} / \mathrm{cm})$ para os elementos filtrantes testados.

Tabela 17 - Anexo 2 do Anexo XX: tabela de padrão de turbidez para água pósfiltração ou pré-desinfecção (origem: Portaria MS/GM no 2.914/2011, Anexo 2) ......99

Tabela 18 - Anexo 7 do Anexo XX: tabela de padrão de potabilidade para substâncias químicas que representam risco à saúde (origem: Portaria MS/GM № 2.914/2011, Anexo 7)..... 
Tabela 19 - Anexo 10 do Anexo XX: tabela de padrão organoléptico de potabilidade (origem: Portaria MS/GM no 2.914/2011, Anexo 10) 102 


\section{SUMÁRIO}

1. INTRODUÇÃO

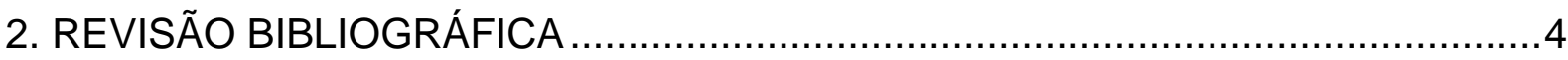

2.1. CONCEITOS SOBRE COMPÓSITOS ESTRUTURAIS E SEUS PRINCIPAIS

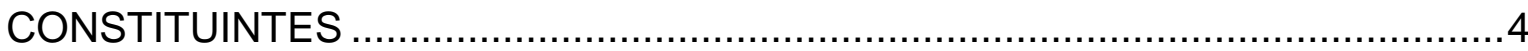

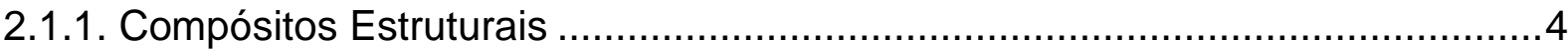

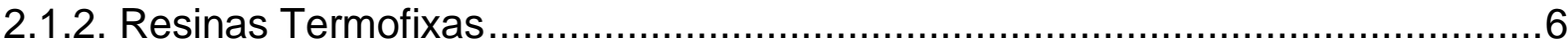

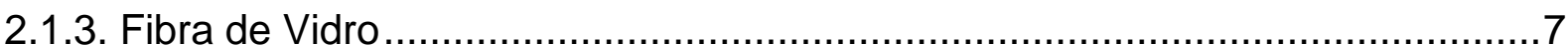

2.2. CONCEITOS SOBRE RECICLAGEM DE MATERIAIS COMPÓSITOS...............8

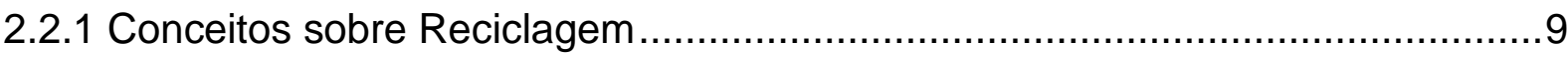

2.2.2. Viabilidade da Reciclagem de Materiais Compósitos.....................................11

2.2.3. Aspectos Legais sobre Reciclagem de Compósitos......................................13

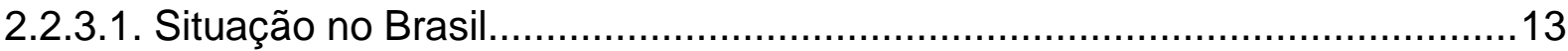

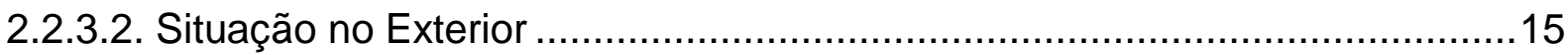

2.3. PRINCIPAIS PROCESSOS DE RECICLAGEM DE MATERIAIS COMPÓSITOS

2.3.1. Reciclagem de Materiais Compósitos Poliméricos: Tipos e Conceitos ...........16

2.3.2. Reciclagem Mecânica (ou Reciclagem Primária/Secundária) .........................18

2.3.2.1. Reciclagem com Separação Parcial de Componentes................................18

2.3.3. Reciclagem Química (ou Reciclagem Terciária) ............................................19

2.3.3.1. Reciclagem via Extração com Fluidos Supercríticos ..................................19

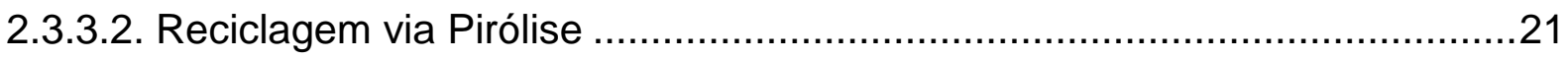

2.3.3.3. Reciclagem via Pirólise com Catalisadores / Vácuo...................................24

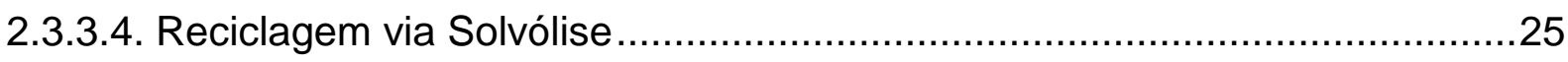

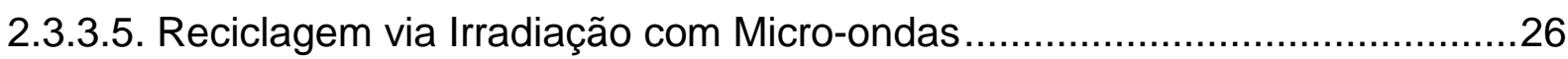

2.3.4. Reciclagem Térmica (ou Reciclagem Quaternária) .....................................28

2.3.4.1. Reciclagem com Separação de Fibras de Reforço ....................................28

2.3.4.2. Reciclagem para Uso em Fabricação de Cimento .......................................30

2.4. CONCEITOS SOBRE MICRO-ONDAS E APLICAÇÕES................................31

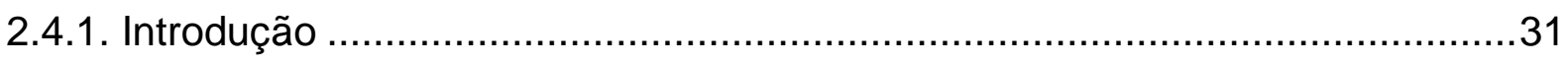

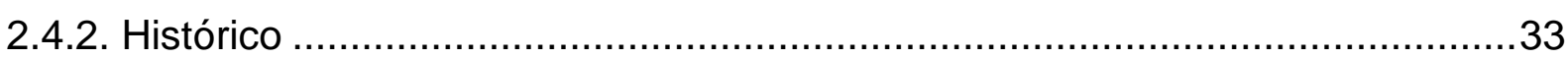

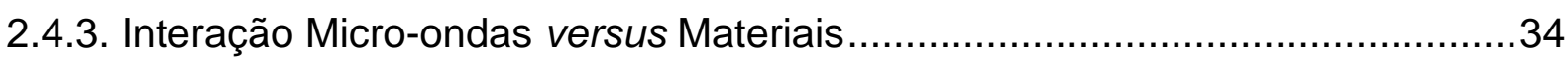




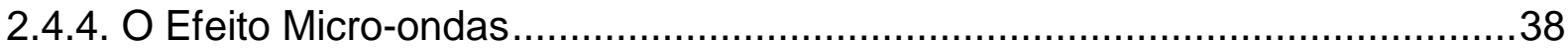

2.5. CONCEITOS BÁSICOS SOBRE FILTRAÇÃO E ADSORÇÃO.........................39

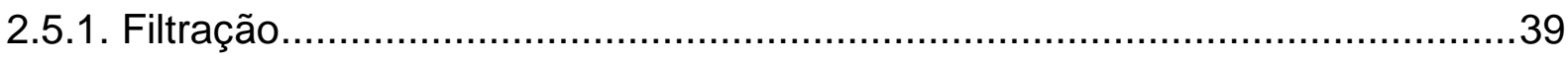

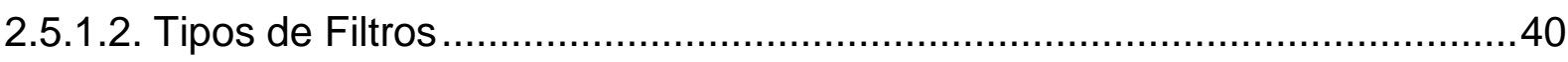

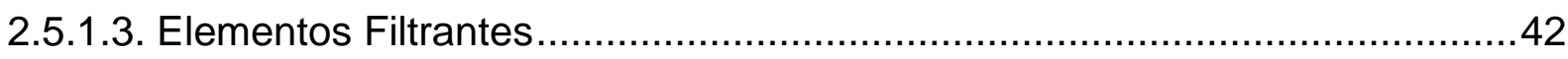

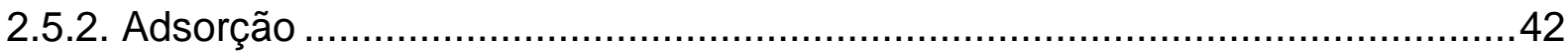

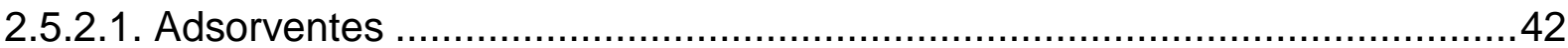

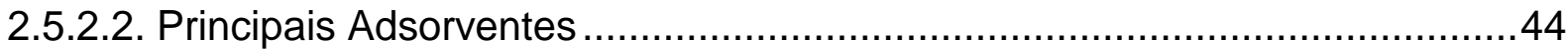

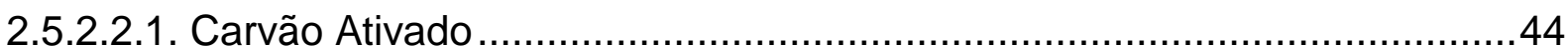

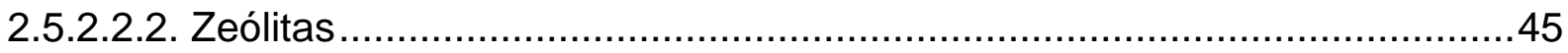

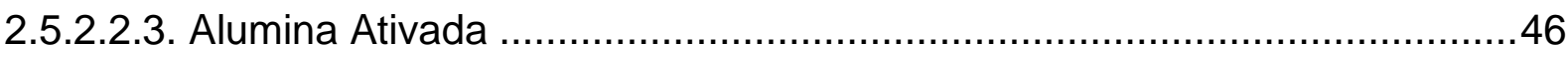

2.6. CONCEITOS BÁSICOS SOBRE POTABILIDADE DE ÁGUA PARA CONSUMO

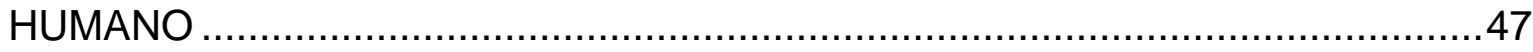

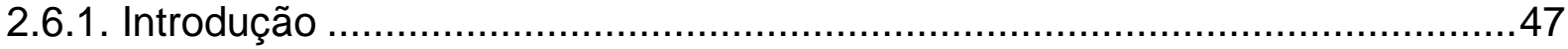

2.6.2. Histórico da Legislação Brasileira ......................................................... 4

2.6.3. Aspectos Legais Importantes sobre Potabilidade........................................ 49

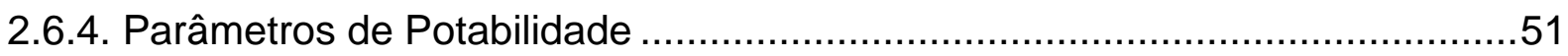

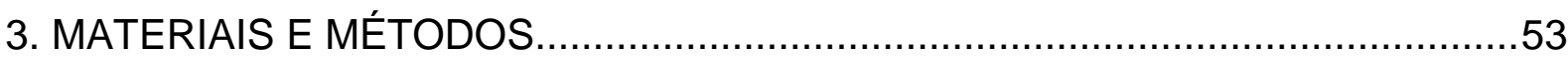

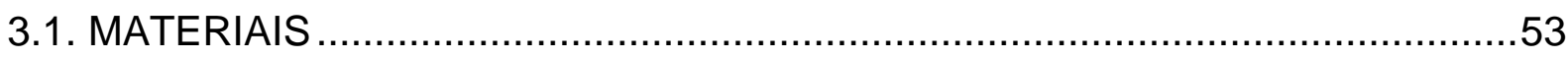

3.1.1. Resíduo de Fibra de Vidro com Resina Epóxi - WOBBEN ............................53

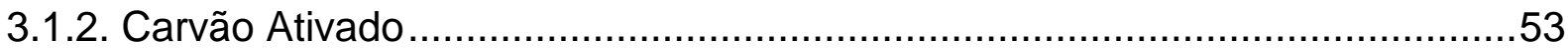

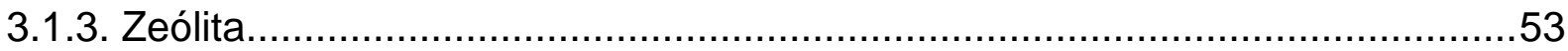

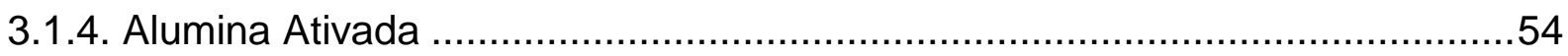

3.1.5. Água para Avaliação Final dos Elementos Filtrantes ….................................54

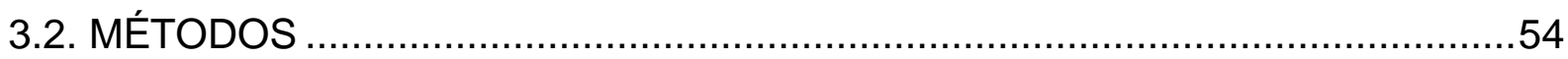

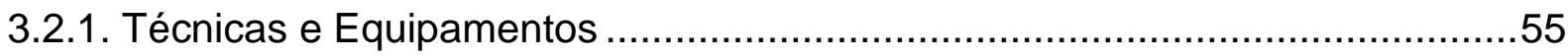

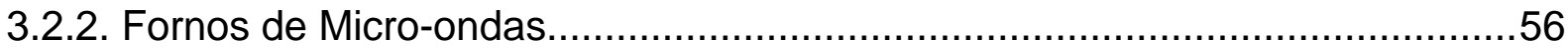

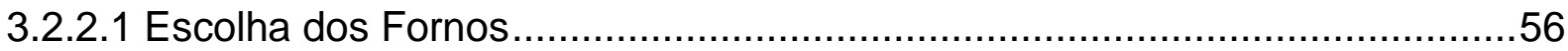

3.2.2.2. Níveis de Potência e Funcionamento ....................................................57

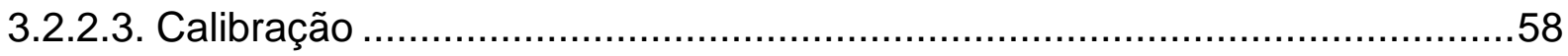

3.2.2.4. Avaliação de Pontos Quentes na Cavidade do Forno .................................59

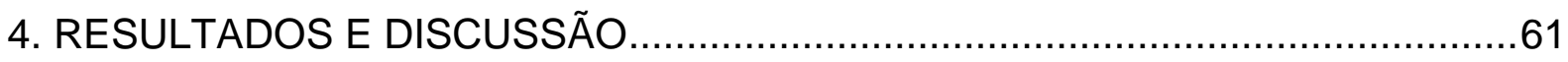

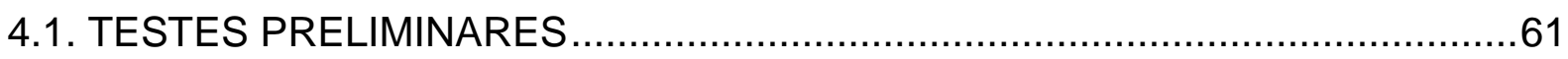

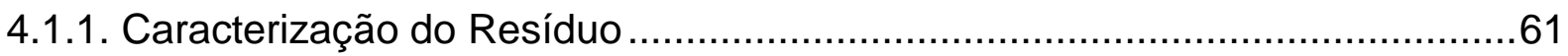




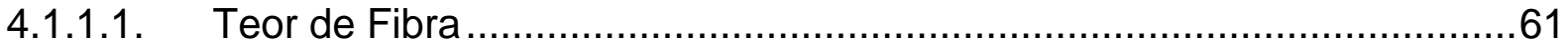

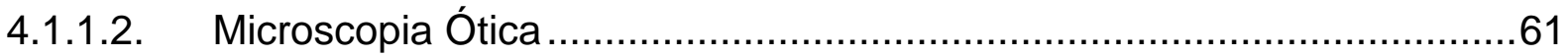

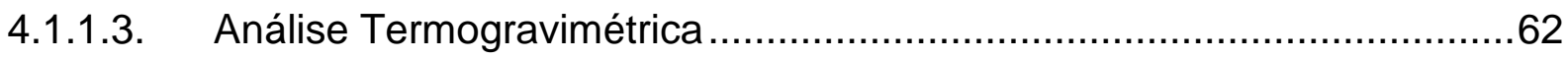

4.1.2. Avaliação Inicial como Elemento Filtrante: Resíduo......................................62

4.2. PROCESSAMENTO POR IRRADIAÇÃO DE MICRO-ONDAS .........................65

4.2.1. Avaliação de Absorção de Energia sob Irradiação .......................................65

4.2.2. Degradação do Resíduo com Carvão Ativado via Irradiação de Micro-ondas 67

4.2.3. Avaliação Inicial como Elemento Filtrante: Resíduo Processado com Carvão

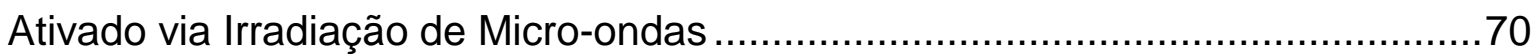

4.3. FILTRAÇÃO COM USO DA ÁGUA DO RIO IPANEMA - IPERÓ/SP ................71

4.3.1. Elementos Filtrantes Utilizados na Filtração.............................................71

4.3.1.1. Elemento Filtrante a partir do Tratamento Térmico do Resíduo em Mufla a Gás

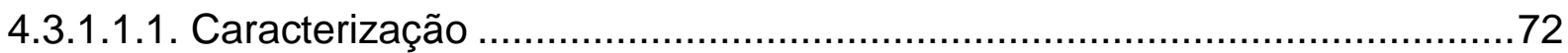

4.3.1.1.1.1. Microscopia Ótica ..............................................................

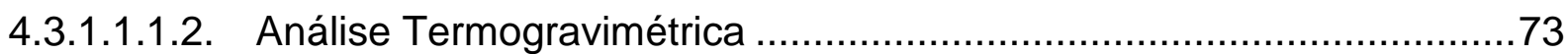

4.3.1.2. Elemento Filtrante a partir do Tratamento Térmico do Resíduo com Carvão

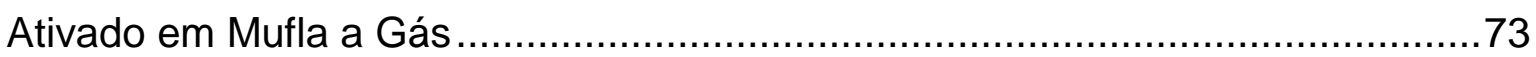

4.3.1.3. Elemento Filtrante a partir do Tratamento Térmico do Resíduo com Carvão Ativado via Irradiação de Micro-ondas ..............................................................74

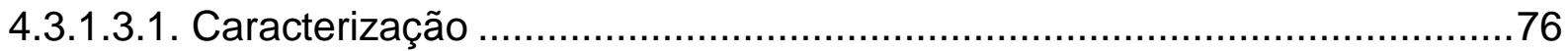

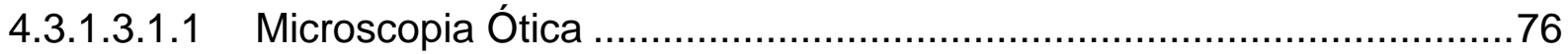

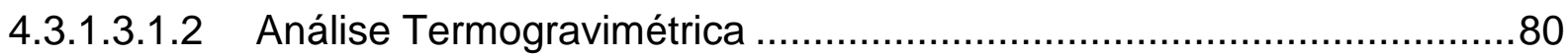

4.3.2. Avaliação Final dos Elementos Filtrantes para Aplicação em Tratamento de

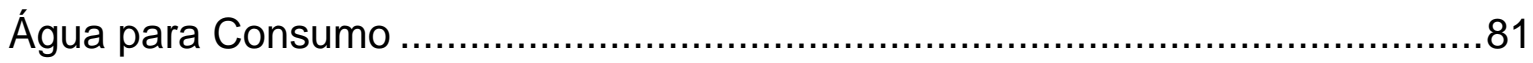

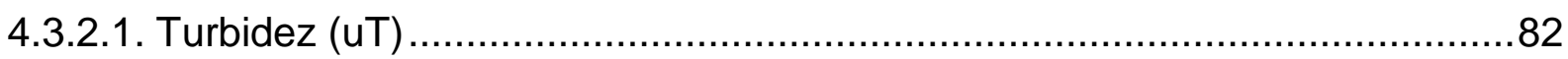

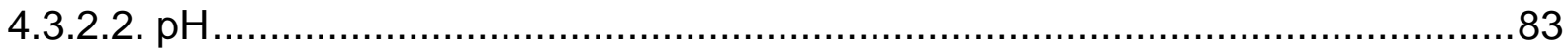

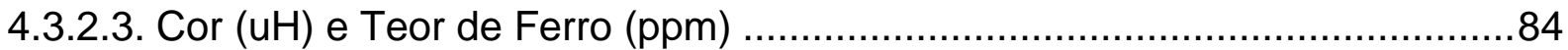

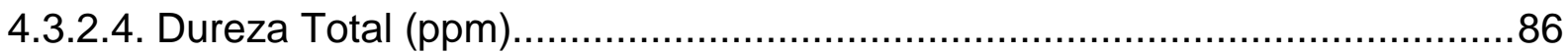

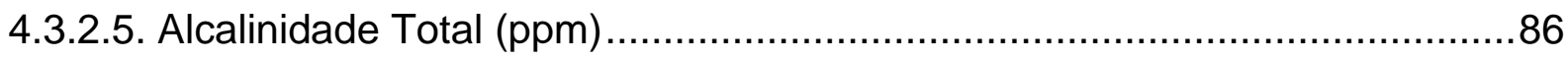

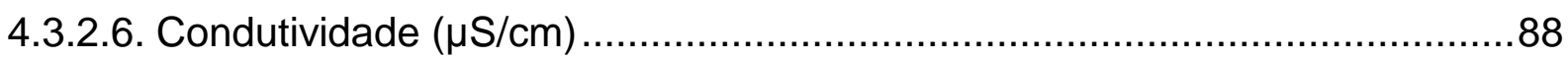

4.3.2.7. Teor de Contaminantes Inorgânicos ...................................................... 88

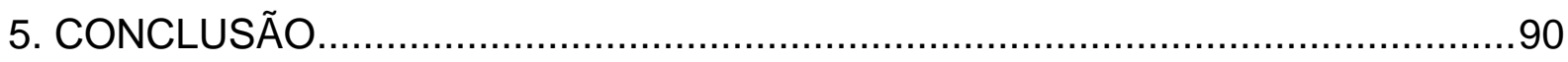

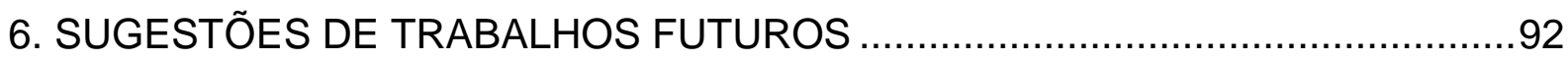




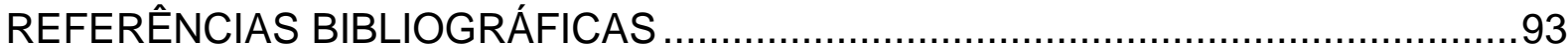

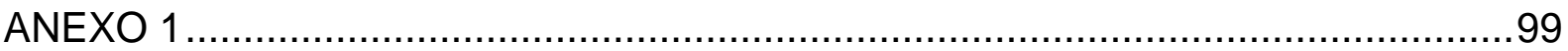

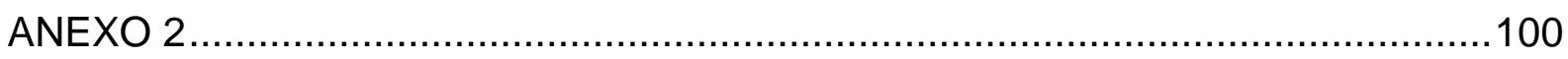

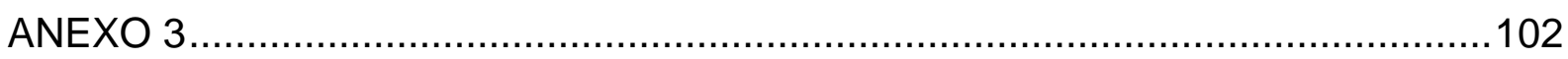

ANEXO 4 


\section{INTRODUÇÃO}

A reciclagem de materiais compósitos é um desafio de engenharia crescente para as mais diversas áreas de conhecimento envolvidas. $O$ tratamento de resíduos de compósitos estruturais produzidos à base de fibras de vidro é um desafio de engenharia que depende diretamente do conhecimento das propriedades físicas, químicas e térmicas dos materiais envolvidos. Considerada a variabilidade existente, dados os diferentes tipos de materiais e processos, a destinação de resíduos de compósitos se torna bastante desafiadora (BRANDUP, 1996).

No caso de compósitos, a aplicação de resíduos como carga, na fabricação de novos materiais, por exemplo, é uma das soluções mais imediatamente aplicadas, em face da complexidade dos materiais compósitos originais e da possibilidade do emprego destes em novas aplicações. Esta opção faz com que os resíduos retornem para consumo dentro do ciclo de vida de utilização de novos materiais compósitos, aumentando o tamanho do passivo, em termos de material usado, para ser tratado no futuro.

A abordagem adotada neste trabalho parte de uma visão diferente: o uso de resíduos de materiais compósitos em aplicação de engenharia distinta de sua utilização original. Esta nova abordagem trata de usar resíduos de materiais compósitos para a aplicação em novos produtos, diferentes do existente na área de compósitos, e que possam, de fato, ter um novo ciclo de vida de utilização, em uma nova aplicação de engenharia.

A aplicação de cada um dos tipos de reciclagem existentes dependerá diretamente das condições do material recebido, bem como a correta definição de seus componentes para a devida destinação. Neste sentido, uma base conceitual foi construída de forma a facilitar a abordagem.

Nesta linha, o presente trabalho considerou a utilização do resíduo fibra de vidro/resina epóxi como elemento filtrante e processamento com micro-ondas, e está dividido da seguinte forma:

A) Conceitos sobre compósitos estruturais e seus principais constituintes;

B) Conceitos e principais processos de reciclagem de compósitos em estudo ou operação no mundo; 
C) Conceitos sobre micro-ondas e suas aplicações no campo de estudo de materiais;

D) Conceitos gerais sobre filtração e adsorção; e

E) Conceitos básicos sobre potabilidade de água para consumo humano.

Depois da apresentação de tópicos sobre o assunto desta pesquisa, são introduzidas as atividades realizadas de forma a encadear os passos seguidos para a aplicação do resíduo de fibra de vidro/epóxi como elemento filtrante. Com foco nesta abordagem, foram estudados os resíduos de aparas de pás eólicas, recebidos na forma de pó composto de partículas de fibra de vidro e pó de resina epóxi curada, na proporção de 64/36 entre fibra de vidro/resina epóxi, respectivamente. A condição de ser inerte quimicamente, por possuir alto teor de fibra de vidro, e sua natureza química ser similar à da sílica, conduziu as primeiras avaliações do resíduo. A similaridade do resíduo com a areia empregada em estações de tratamento de água conduziu aos primeiros testes em laboratório para uso como elemento filtrante para água.

Neste sentido, foram realizadas verificações com relação à aplicação do resíduo como filtro sem quaisquer tratamentos físico ou químico. Inicialmente foi realizada a caracterização do resíduo, com ensaios envolvendo a medição de teor de fibra/resina, microscopia ótica, e análise termogravimétrica. Após estes ensaios, os primeiros testes do resíduo na forma de elemento filtrante foram feitos. O filtrado obtido evidenciou que a alternativa escolhida era acertada. Foi notada nítida melhora na turbidez da amostra de água testada. Para evidenciar se o resíduo, em contato com água, desprendeu produtos solubilizados, foi executada uma extração a quente, seguida de ensaios de Infravermelho (FTIR). Os resultados foram inconclusivos, levando o trabalho de pesquisa para um novo patamar. O uso do resíduo como um pré-filtro simples, para a redução de turbidez de água, tornou-se o primeiro resultado deste trabalho. As atividades seguintes vieram no sentido de avaliar a possibilidade de uso do resíduo após o devido processamento da fase orgânica original presente, potencial fonte de contaminantes.

Para este processamento, foi escolhida a irradiação por micro-ondas, com a presença de absorvedores de energia. Buscando agregar mais propriedades ao novo elemento filtrante, foram escolhidos absorvedores químicos (carvão ativado, alumina ativada e zeólitas) como absorvedores de energia. Após testes, o potencial do carvão ativado ficou evidenciado, sendo o mesmo empregado da degradação da fase orgânica do resíduo. Imediatamente após o processamento, uma nova avaliação 
do material obtido como elemento filtrante foi realizada com o uso de água de cursos d'água da região de Sorocaba. Após filtração, foram obtidas melhoras mais evidentes no quesito turbidez e alterações relevantes no pH, TDS (Teor de Sólidos Dissolvidos), teor de $\mathrm{O}_{2}$, teor de sais e condutividade elétrica. Em face aos resultados obtidos, novos testes de filtração foram realizados com amostra de água proveniente do rio Ipanema, curso d'água classe 1, que corta a reserva florestal de mesmo nome.

Nos novos testes de filtração, com parâmetros atinentes à qualidade da água, foram avaliados: turbidez, pH, cor, teor de Ferro, dureza total, alcalinidade total, condutividade elétrica e teor de contaminantes inorgânicos (metais alumínio, arsênico, bário, cádmio, cromo, cobre, mercúrio, manganês, níquel, chumbo, antimônio, selênio e zinco). Para a avaliação final no trabalho, foram testadas nove composições de elementos filtrantes diferentes, onde foi possível comparar os resultados obtidos para diferentes tipos de processamento (irradiação por micro-ondas com carvão ativado, e queima via mufla a gás), tempos de processamento por irradiação via micro-ondas, tipos de configuração de filtro (filtro sanduíche e filtro simples), e filtração com elementos filtrantes sem processamento (resíduo original, carvão ativado, alumina ativada e zeólitas).

Ao final do trabalho, são apresentadas as conclusões obtidas após todos os testes realizados, credenciando a aplicação do resíduo de fibra de vidro/resina epóxi como um bom elemento filtrante primário, para uso como pré-filtro, reduzindo a turbidez de águas com alto teor de partículas sólidas em suspensão, entre outras características necessárias para tratamento inicial de águas residuárias. 


\section{REVISÃO BIBLIOGRÁFICA}

\subsection{CONCEITOS SOBRE COMPÓSITOS ESTRUTURAIS E SEUS PRINCIPAIS CONSTITUINTES}

\subsubsection{Compósitos Estruturais}

Material compósito, ou simplesmente compósito, é um tipo de material composto de dois ou mais materiais reunidos com o objetivo de associar e agregar as melhores propriedades de ambos. Compósitos são constituídos de duas partes: uma matriz, que pode ser um polímero, uma cerâmica ou outro material que sirva como meio agregante, e um outro material chamado reforço, que atua agregado à matriz $\mathrm{e}$ que fornece normalmente boa parte das propriedades especiais do compósito. Dentre os materiais que podem atuar como reforço tem-se fibras de vidro, carbono, polímeros (nylon, por exemplo) e metais (CALLISTER, 2001).

Historicamente, a Bíblia descreve os primeiros compósitos registrando a mistura palha e galhos com argila ou barro para a fabricação de casas. Estes são primeiros relatos do uso de materiais compósitos que hoje fazem parte de nossa sociedade das mais diferentes maneiras (PORTAL ECOEFICIENTES, 2019).

Daquela época para hoje, a evolução dos materiais possibilitou a constituição das mais diferentes combinações, proporcionando a criação de materiais com características especiais. Na evolução da aplicação do concreto armado, reparos e reforços hoje também são feitos com materiais compósitos a base de fibra de carbono e resinas termofixas (NPPG, 2019).

O desenvolvimento tecnológico na área de ciência e engenharia de materiais tem propiciado a criação de diferentes tipos de novos materiais. Até poucos anos atrás, o desenvolvimento de materiais compósitos em escalas nanométricas era algo ainda completamente novo. O uso de nanotubos de carbono associados a compósitos produzidos com fibra de carbono/resina epóxi é um exemplo desta nova realidade, com boas propriedades físicas e boas propriedades mecânicas conjugadas em condições não imaginadas até então (ZHANG, 2019).

Impulsionando a produção de compósitos, diversas qualidades dos 
materiais compósitos podem ser citadas, dentre as quais têm-se:

- alta resistência a tensões e baixa massa específica;

- moldagem em diferentes formas, com uma boa resistência em diferentes condições de serviço;

- boa resistência ao impacto, compressão e fadiga;

- bom isolamento elétrico;

- possibilidade de produção de peças em grande escala em uma única etapa de moldagem;

- baixo a moderado custo de manutenção;

- bom custo de produção.

Face às suas propriedades, o campo de aplicações é extenso, podendo-se utilizar os compósitos em aplicações comuns como artigos esportivos ou utensílios domésticos, até aplicações especiais de engenharia ou estruturais. Os compósitos que são objetos de estudo neste trabalho incluem-se neste último grupo: os compósitos estruturais.

Compósitos estruturais são uma classe de materiais compósitos cujas propriedades dependem também da geometria dos elementos constituintes entre si. Dentre as principais configurações existentes têm-se os compósitos estruturais do tipo laminar, e os compósitos estruturais do tipo sanduíche. Eles têm muita aplicação na engenharia aeronáutica (aviões para uso civil e militar), engenharia civil (pontes, prédios, reparos estruturais em concreto, entre outras), e energia (tanques para combustíveis, pás de geradores eólicos, entre outras). Os compósitos estruturais do tipo laminar são materiais compostos de diferentes camadas ou painéis sobrepostos entre si, de forma que cada uma das partes constituintes é montada em direções específicas pré-determinadas, com o objetivo de maximizar as propriedades físicas, mecânicas, elétricas, etc., de interesse em sua aplicação final. Dentre as aplicações conhecidas de compósitos laminares, tem-se o uso em vasos de pressão, dutos para fluidos, pás para geradores eólicos, entre outros usos em engenharia (ELHAJJAR, 2019).

Os compósitos estruturais tipo sanduíche são materiais compostos de uma estrutura constituída de três camadas: duas camadas finas externas resistentes mecanicamente, feitas de tecidos ou mantas de uma determinada fibra, e uma camada central interna espessa, menos rígida e menos densa, feita de espumas ou 
estruturas tipo colméia (honeycombs). A parte central ou núcleo é o grande diferencial deste tipo de compósito, e atua estruturalmente com duas funções:

- separar as faces externas, deformando perpenticularmente ao plano das faces; e

- prover resistência ao cisalhamento ao longo do plano perpenticular às faces externas.

Os principais usos ao qual se destacam os compósitos tipo sanduíche são em aplicações aeronáuticas, em partes da estrutura externa de aviões como cobertura de asas, e fuselagem, e na indústria da construção civil, na confecção de paredes, tetos e pisos (ELHAJJAR, 2019).

As desvantagens com relação aos compósitos, de modo geral, surgem quando consideradas as propriedades do constituinte que atua como matriz. No caso de materiais compósitos estruturais termofixos, o polímero/resina é o componente que indica as principais restrições existentes. Algumas das desvantagens mais relevantes para este caso em específico são as seguintes(STARR, 2000):

- baixa tenacidade em comparação com diversos materiais tradicionais;

- limitada resistência térmica, que com exceções, pode ser maior que 200 $\stackrel{\circ}{\circ}$; e

- limitado reaproveitamento e/ou reciclagem no processo de fabricação, sendo triturados e utilizados como carga quando possível.

Em face da importância das propriedades das resinas termofixas, as mesmas serão apresentadas logo a seguir, em um tópico à parte. As características das resinas termofixas utilizadas como matriz influenciam também nos processos de reciclagem a serem usados futuramente.

\subsubsection{Resinas Termofixas}

As resinas termofixas são materiais compostos de macromoléculas ligadas umas às outras de forma a resultar em um polímero infusível e insolúvel a solventes comuns. Esta classe de polímeros, após passar por uma reação de cura, forma uma estrutura semelhante a uma rede tridimensional que não pode ser desfeita por uma simples adição de calor. Dessa forma, os polímeros termofixos, ao serem submetidos ao primeiro ciclo de amolecimento por aquecimento, moldagem e endurecimento por resfriamento, não podem ser novamente amolecidos e moldados (ODIAN,1991 e 
MANRICH,1997).

As ligações químicas ancoram uma cadeia à outra, provocando resistência a movimentos vibracionais ou rotacionais a altas temperaturas. A reticulação (processo de cura do polímero) é sempre extensiva, de forma a englobar 10 a 50\% dos meros da cadeia principal. Somente o aquecimento excessivo pode provocar alguma alteração no polímero, causando degradação do material. Para cada termofixo, variando-se os reagentes iniciais, ocorre a possibilidade de variar a composição e a estrutura molecular (GOODSHIP, 2007 e STEVENS, 1999).

$\mathrm{Na}$ área de fabricação de compósitos, as resinas termofixas têm poucas aplicações em sua forma pura, sendo necessários aditivos para melhorar a processabilidade. As formulações para a utilização deste tipo de polímero em materiais compósitos normalmente compreendem uma resina (com endurecedores, inibidores e plastificantes) e cargas ou reforços. A resina e seus aditivos conferem coesão à mistura, fornecendo estabilidade dimensional, estabilidade ao calor, resistência química e resistência à chama.

Os reforços podem influenciar nas propriedades também, sobretudo na estabilidade dimensional e ao calor, mas seu efeito principal é na tensão de ruptura e tenacidade do produto final. Cargas especiais e aditivos podem influenciar também nas propriedades mecânicas, especialmente na estabilidade dimensional, mas elas são usadas principalmente para conferir uma melhor resistência a chama, estabilidade frente a radiação ultravioleta (UV) ou resistência elétrica.

\subsubsection{Fibra de Vidro}

Os primeiros usos que se tem registro de fibra de vidro datam da Antiguidade. Artesãos egípcios, após a fusão de diferentes tipos de misturas de óxidos, produziam manualmente fibras curtas, de diversas cores para fins decorativos. Este conhecimento foi mantido com o passar dos anos, permanecendo quase o mesmo até o final do século XIX. Com o advento da Revolução Industrial, novos processos para produção de materiais foram desenvolvidos, incluindo-se neste contexto também a fabricação de fibras de vidro. Nos primeiros anos do século XX, foram estabelecidas na Alemanha e Inglaterra as primeiras plantas comerciais para a produção de fibras curtas. Em 1938, foi estabelecido pela empresa Owens-Corning o primeiro processo 
para a fabricação de fibras longas, para uso em isolamento térmico de motores.

Os primeiros usos de fibra de vidro como reforço datam dos anos de 1940, quando durante o esforço de guerra empreendido pelos EUA, uma certa quantidade de resina poliéster catalisada caiu, por acaso, sobre algumas camadas de fibra de vidro, acidentalmente. O novo material mostrou-se bastante resistente e leve em comparação com os demais materiais, sendo imediatamente utilizado na fabricação de tanques de combustível, domos para radar, entre outras aplicações. Este foi o início do uso de fibra de vidro como reforço em materiais compósitos (WARRING,2008).

A fabricação de fibras de vidro iniciou-se com a mistura das matérias-primas em um misturador mecânico, a seco, até completa dispersão. Logo após a mistura, a massa resultante é conduzida para um forno refratário, onde é aquecida a cerca de $1450^{\circ} \mathrm{C}$. A transformação da massa fundida em fios é feita pelo processo de fiação por fusão. O vidro fundido é conduzido para uma placa de platina com milhares de furos com dimensão controlada (microfuros, de 12 a $16 \mu \mathrm{m}$ ), também conhecida como fieira, resultando por fim na obtenção de filamentos contínuos. O diâmetro das fibras de vidro também pode ser afetado por outros fatores além do diâmetro da fieira. Variações na temperatura da fieira e na velocidade da bobinadeira, ao final do processo de fiação, também podem provocar alterações no produto final obtido. Estes parâmetros alteram a densidade linear de material, resultando em fios mais finos ou espessos conforme a necessidade.

Após a saída da fieira, as fibras recebem um tratamento superficial conhecido como encimagem. Este tratamento tem diversas funções dentre elas prover flexibilidade ao material, promover adesão aos polímeros que serão usados como matriz, e proteção superficial para manuseio e contato com equipamentos. Para a produção de tecidos, mantas, e outros produtos a partir de fibras longas ainda também são adicionados a encimagem agentes lubrificantes para proteção das fibras ao contato com elementos mecânicos e cerâmicos dos teares (KNOX,1982).

\subsection{CONCEITOS SOBRE RECICLAGEM DE MATERIAIS COMPÓSITOS}




\subsubsection{Conceitos sobre Reciclagem}

A reciclagem é uma das grandes possibilidades existentes atualmente para destinação de resíduos sólidos, pois traz opções para a resolução de problemas de destinação de resíduos sólidos relacionados ao meio ambiente, sociedade e economia. $\mathrm{Na}$ definição adotada pela EPA (Environmental Protection Agency), a agência ambiental dos Estados Unidos, reciclagem é a ação de coletar, reprocessar, comercializar e utilizar materiais antes considerados como lixo.

A reciclagem é o "resultado de uma série de atividades por meio da qual materiais que se tornariam lixo, ou estão no lixo, são desviados, sendo coletados, separados e processados para serem usados como matéria-prima na manufatura de bens, feitos anteriormente apenas com matéria-prima virgem" (ROLIM,2000).

Infelizmente, para o correto emprego e funcionamento dos processos de reciclagem, é necessário o estabelecimento da devida infraestrutura para que o processo seja realizado, bem como, uma definição clara da sociedade local (onde os resíduos são gerados) de como ela quer tratar abordar a situação. Com a promulgação da Política Nacional de Resíduos Sólidos (Lei oㅜ 12.305, de 02 de agosto de 2010), novas diretrizes foram lançadas, definindo os papéis de cada um dos envolvidos no processo, desde a geração até a destinação final, para cada um dos tipos de resíduos existentes. Os aspectos legais sobre reciclagem serão discutidos em um item a parte (BRASIL,2010).

Considerada a potencialidade da adoção de processos de reciclagem para destinação de resíduos sólidos, o primeiro passo é entender o processo de reciclagem e entender os grupos envolvidos neste processo, desde a geração do resíduo sólido, até como ele vai ser aproveitado. Assim, a reciclagem é um conjunto de processos onde é notável a necessidade da criação de uma série de agentes que atuem sobre o resíduo sólido e o tornem algo realmente reaproveitável. Como o foco deste trabalho é um dos resíduos recicláveis, maior a dependência que um sistema de triagem e reciclagem funcione adequadamente.

$\mathrm{Na}$ Figura 1, um esquema é mostrado com as principais etapas que ocorrem com a geração de resíduos. Desde a fabricação até o reaproveitamento via reciclagem, bem como as demais alternativas possíveis atualmente (aterros sanitários, compostagem, e incineração) (DASKAPOULOS, BADR, PROBERT,1997). 
Figura 1 - Esquema com etapas necessárias para reciclagem, e outras alternativas de destinação existentes (aterro sanitário, compostagem e incineração)
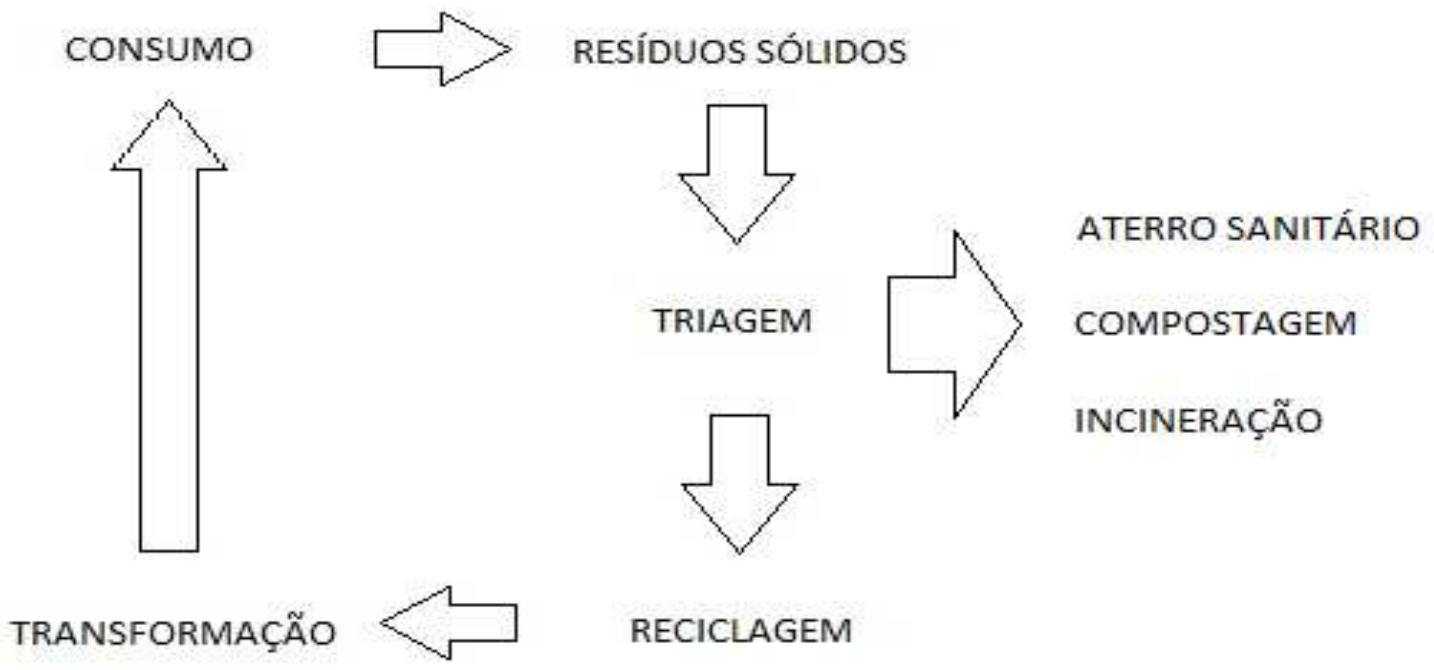

RECICLAGEM

Fonte: Daskapoulos, Badr, Probert,1997.

A população, através do consumo de produtos, gera resíduos que devem ser coletados e separados. A coleta pode ser pelo meio convencional, com o material reciclável e o material não reciclável coletados juntos (misturados) ou pela coleta seletiva (WIEBECK,2004).

Descrito como funciona o sistema, cabe ressaltar outro fator importante. As implicações econômicas para a viabilidade do processo normalmente são o ponto decisivo para o início de um estudo sobre reciclagem. Diversos processos de reciclagem de determinados produtos, do ponto de vista ambiental e ecológico, são bastante interessantes, mas carecem de motivação econômica para que sejam implantados.

Desta forma, para garantir a sustentação econômica da reciclagem devem ser levados em consideração os seguintes fatores:

- existência de demanda de mercado para o resíduo;

- proximidade da fonte geradora com o local onde será reciclado o material;

- quantidade de material disponível e condições de limpeza;

- custo de separação, coleta, transporte, armazenamento e preparação do resíduo antes do processamento;

- custo de processamento e transformação do resíduo em novo produto;

- existência de demanda de mercado para o produto resultante da 
reciclagem;

- existência de tecnologia (processo) para efetuar a transformação do resíduo; e características e aplicação do produto resultante.

\subsubsection{Viabilidade da Reciclagem de Materiais Compósitos}

Como uma regra geral para reciclagem de qualquer material de engenharia, cada processo de reciclagem envolve uma cadeia de operações as quais uma depende da outra. Um problema em alguma etapa desta cadeia implica que o processo de reciclagem não poderá ser completado. Na Figura 2 é mostrado um sistema de reciclagem para materiais compósitos, e dentre os fatores relevantes para o funcionamento do processo tem-se os seguintes quatro pontos a seguir (YANG,2012):

- Disponibilidade de resíduos de compósitos: esta é a fonte de materiais compósitos para reciclagem, que pode ser de consumidores de produtos que atingiram o final de sua vida útil (EOL, end-of-life), ou resíduos "velhos", ou pode ser de resíduos de processos de produção, ou resíduo "novo". Materiais compósitos são de pequeno volume de produção e de geração de resíduos pós-consumo se comparados com metais e outros tipos de polímeros não compósitos. Isso levará a um limite de disponibilidade de resíduos de compósitos para execução de uma reciclagem economicamente viável;

- Coleta e transporte - um sistema de coleta apropriado e eficiente para velhos e novos resíduos: a coleta e transporte de produtos já consumidos é uma das etapas essenciais dentro de um sistema de reciclagem. Atualmente, a coleta de veículos usados (ELV, end-of-life vehicles) e aviões e peças de aviões usados (EOL aircrafs) é muito bem organizada em alguns países da Europa, sendo o transporte desses produtos para áreas apropriadas de tratamento dependente do tamanho material a ser processado. ELVs são facilmente transportados para empresas de desmanche de carros, para depois serem enviados para empresas de trituração. Por outro, aviões e peças de aviões, face ao seu tamanho, necessitam de ser desmontadas e trituradas em pequenos pedaços para facilitar o transporte. Para o caso de produtos 
eletrônicos pequenos e materiais para esporte e recreação, coletas incompletas, assim como baixas taxas de coleta, ainda são um problema;

Figura 2 - Sistema de reciclagem para materiais compósitos

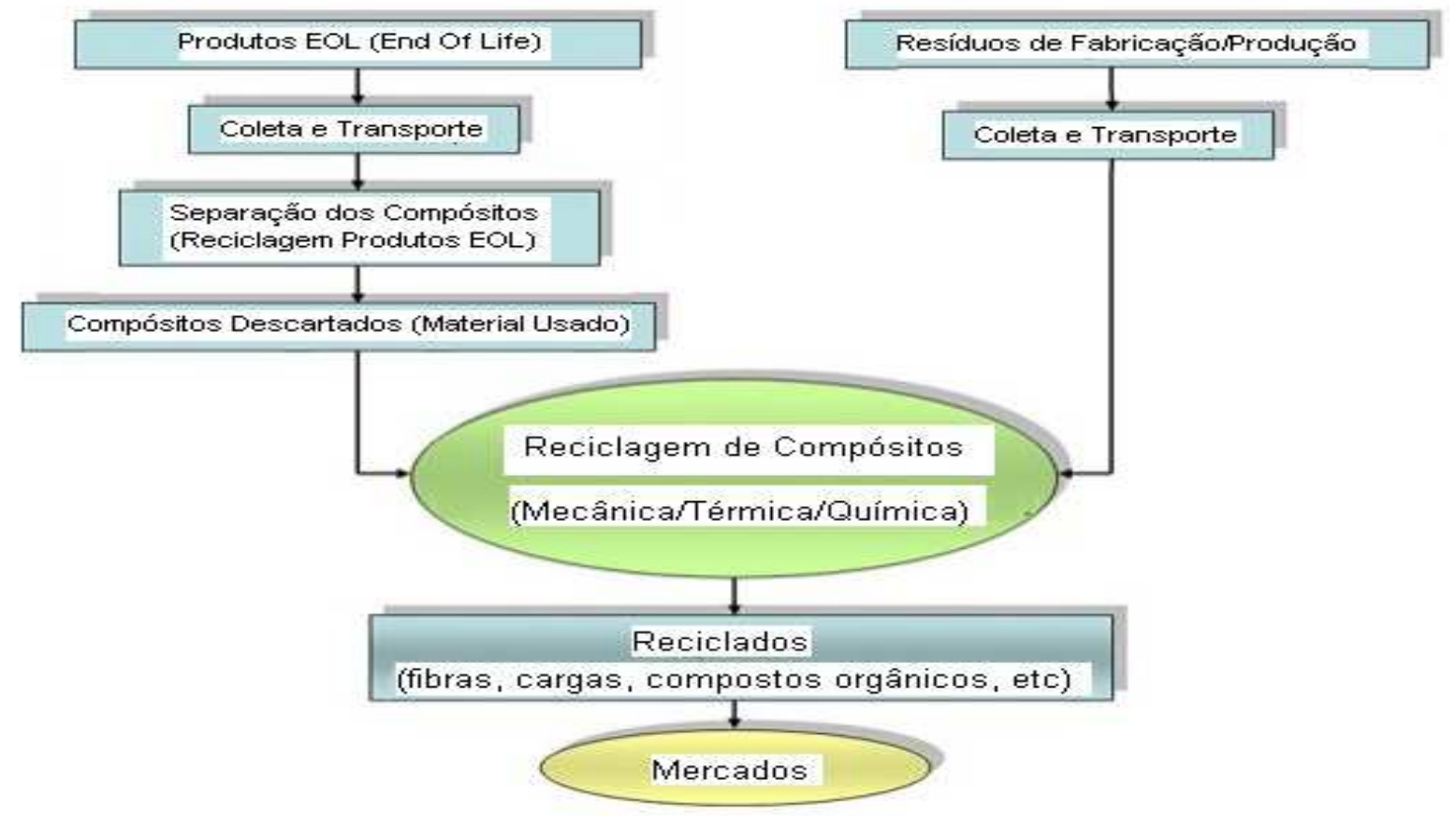

Fonte: Yang,2012.

- Reprocessamento - reciclagem: essas podem ser por meio de processos físicos (mecânicos), térmicos, ou químicos, dependendo do tipo de material compósito. Esta etapa é o centro de toda a cadeia de operação do sistema de reciclagem. A maioria dos processos desenvolvida é resultado de pesquisas privadas. Infelizmente, a maioria das tecnologias disponíveis para reciclagem de compósitos enfrenta dificuldades para determinar as condições para a obtenção de produtos com qualidade, seguir as legislações ambientais existentes, e operar dentro de condições economicamente viáveis. Existe uma considerável demanda por processos de separação mais eficientes, e que possam seguir as condições acima descritas; e

- Mercado para produtos reciclados: o mercado necessita de que os produtos reciclados possuam qualidade e preços competitivos quando comparados com os produtos virgens. O principal desafio atual é superar a perda de mercado para os produtos reciclados (YANG,2012). 


\subsubsection{Aspectos Legais sobre Reciclagem de Compósitos}

\subsubsection{Situação no Brasil}

Os primeiros sinais de legislação ambiental começaram no final da década de 1980. Em 1999 foram elaboradas as "Diretrizes Técnicas para a Gestão de Resíduos Sólidos", aprovadas pelo Governo Federal, mas sem entrar em vigor. Com o passar dos anos o tema conseguiu grande repercussão no poder legislativo, até que em 2007 foi enviado para análise do Presidente da República. Após várias discussões, a Lei no 12.305 - Política Nacional de Resíduos Sólidos - foi aprovada em 02 de agosto de 2010, dando início ao processo árduo de conscientização em busca da necessidade de mudança de conduta com relação aos resíduos sólidos de modo geral. Foi o início das discussões quanto aos lixões e demais formas de destinação irregulares e prejudiciais ao meio ambiente. Até então, não existia uma lei específica relacionada aos resíduos sólidos sem interface com outras leis e era necessária a criação de legislação atinente ao tema.

Até a criação da Política Nacional de Resíduos Sólidos foram criadas diversas leis, dentre estas destacam-se a Lei o 11.445 - Diretrizes Nacionais para Saneamento Básico - de 05 de janeiro de 2007, a Lei no 9.974 - sobre manuseio e operações diversas com Agrotóxicos - de 06 de junho de 2000, e a Lei oo 9.966 sobre Contaminação das Águas - de 28 de abril de 2000. Esta sequência de leis ambientais, de 2000 a 2007, demonstra a importância crescente em estabelecer uma legislação esclarecedora, rígida e individualizada quanto à questão dos resíduos sólidos.

A Lei oㅜ 11.445 cita, no seu artigo 3oㅡㄹ inciso I, letra c "a limpeza urbana e o manejo de resíduos sólidos" como parte integrante do processo de saneamento (serviços, estruturas e instalações operacionais) que fazem parte integrante do subproduto do saneamento. Tal fator é importante para esta e outras leis citadas anteriormente, a partir do momento em que o termo "resíduo sólido" é citado com a devida relevância que o assunto merece. Assim, numa escala crescente de importância de 2007 a 2010, quando a Lei o 12.305 é criada e sua punição estabelecida em lei já existente (Lei n 9.605 - sobre Crimes Ambientais - 12 de fevereiro de 1998), o tema "resíduos sólidos" já é consolidado no aspecto legal. Este 
enquadramento realizado na Lei de Crimes Ambientais salienta o grau de relevância sobre a gestão integrada dos resíduos sólidos e esclarece as possíveis consequências sobre danos causados (CORBUCCI NETO, 2012).

Considerado o tempo decorrido, a legislação ambiental nacional evoluiu relativamente rápido. Apesar disso, diferentemente de outros países, no Brasil, a legislação não evoluiu a ponto de tratar a reciclagem de materiais compósitos, ou ao menos as suas principais fontes, de maneira especial. O principal marco legal existente, a Lei Federal ํㅜ 12.305, fornece as linhas gerais para a gestão de resíduos sólidos, salientando "os princípios, objetivos e instrumentos; diretrizes relativas à gestão integrada e ao gerenciamento de resíduos sólidos, incluindo os perigosos; responsabilidades dos geradores e do poder público; e instrumentos econômicos aplicáveis". No contexto da Política Nacional de Resíduos Sólidos, os resíduos podem ser classificados por sua origem, sendo a cada um deles associada a responsabilidade para destinação final. A Lei no 12.305 apresenta o conceito de responsabilidade compartilhada: "é instituída a responsabilidade pelo ciclo de vida dos produtos a ser implementada de forma individualizada e encadeada, abrangendo: fabricantes, importadores e distribuidores, comerciantes e os consumidores, titulares dos serviços públicos de limpeza urbana e de manejo de resíduos sólidos”. O conceito foi concebido de forma ampla, de forma que os resíduos de materiais compósitos estruturais, produzidos a partir de fibra de vidro e de fibra de carbono, pela sua natureza de utilização, não se encaixam em resíduos domiciliares, comerciais ou públicos, cabendo aos fabricantes do material providenciar a sua destinação.

De fato, a lei atual indica a destinação de resíduos, e salienta, sobretudo, o conceito de responsabilidade compartilhada pelo ciclo de vida de produtos. Assim, o fato de não existir um instrumento legal responsabilizando textualmente o fabricante pelo seu produto não quer dizer que o mesmo esteja isento de providenciar a correta destinação. Conforme a Lei nº 12.305, esta lógica é válida para produtos mais simples, como embalagens de alimentos, até para artigos mais complexos, como máquinas e equipamentos eletrônicos, sejam nacionais ou importados. É um assunto controverso, pois a sociedade de modo geral (Prefeituras e Geradores) ainda não está pronta para as implicações constantes na legislação, e a sua fiscalização iniciou-se em agosto de 2012 (NUNES,2012).

Reforçando a necessidade de cumprimento da lei, em 23 de outubro de 2017 o Governo Federal publicou o Decreto Federal ํo 9.177 que instaurou a isonomia, 
em relação à fiscalização e no cumprimento das obrigações, dos responsáveis pelo ciclo de vida do produto. Isso significa que a fiscalização ocorrerá para todos os responsáveis (fabricantes, importadores, distribuidores e comerciantes) de forma igual. Com isso, várias organizações iniciaram um processo de criação de planos de resíduos sólidos e acordos setoriais com o objetivo de cumprir a Política Nacional de Resíduos Sólidos, produtores de material compósito inclusive.

Neste contexto a CETESB (Companhia Ambiental do Estado de São Paulo) publicou a Decisão de Diretoria no 76/2018/C. Esta regulamentação indica que somente é possível a renovação da Licença Ambiental, no Estado de São Paulo, das empresas que comprovarem seu processo de logística reversa. Em São Paulo também, as empresas associadas a FIESP assinaram Termo de Compromisso com o Governo Federal, de forma a balizar as ações. Em outros estados, como Mato Grosso do Sul, já estão ocorrendo autuações em função do Decreto Federal no 9177 (EURECICLO,2018).

Já existem algumas iniciativas para a implementação de sistemas de logística reversa no Brasil para materiais compósitos. Infelizmente estas iniciativas ainda abrangem apenas alguns tipos de materiais compósitos, as quais estão condicionados a acordos e parcerias com fabricantes para a definição dos custos envolvidos (DEVOLVA,2019).

A principal iniciativa dentro do mundo dos compósitos no Brasil é a Compolife, organizada pela ALMACO (Associação Latino-americana de Materiais Compósitos). O programa entrou em operação em agosto de 2016 com o estabelecimento de Termo de Compromisso entre a Secretaria do Meio Ambiente e Recursos Hídricos do Estado do Paraná (SEMA-PR), o Instituto Ambiental do Paraná (IAP) e a ALMACO, para a implantação de sistema de logística reversa de materiais compósitos usados.

O segmento Transportes - Ônibus foi estabelecido inicialmente para reciclagem de componentes como tetos, grades e para-choques. O destino final dos materiais é o coprocessamento em fornos de cimenteiras, alternativa de reciclagem energética reconhecida internacionalmente, sendo os resíduos da incineração incorporados na fabricação do cimento (ALMACO,2019).

\subsubsection{Situação no Exterior}


Assim como ocorre atualmente no Brasil, não existe uma legislação específica para a gestão de resíduos de material compósito na maior parte dos países no Exterior. Os materiais compósitos, em face de sua inércia química e estabilidade dimensional, são, em sua maior parte, tratados como resíduos industriais, sendo encaminhados para aterros industriais, quando existe espaço para este tipo de destinação, ou para sistemas de incineração, quando permitido (ESTADOS UNIDOS DA AMÉRICA,2012). A situação que mais se destaca com relação à gestão de resíduos de materiais compósitos no Exterior é a dos países da Europa.

As ações tomadas pela União Européia para a proibição da destinação de materiais compósitos em aterros, ou destinar através de incineração, e a obrigatoriedade do tratamento de outros tipos de resíduos de produtos pós-consumo, como carros, por exemplo, vêm a motivar o amplo tratamento e destinação de todo o tipo material presente nestes dois tipos de resíduos, e indiretamente, tratar de materiais compósitos. Comparativamente ao caso brasileiro, a União Europeia atualmente, por força de regulação legal, indica a existência de sistemas de logística reversa para carros, entre outros tipos de resíduos de grande volume e/ou importância. A legislação existente para gestão de veículos em fim de vida útil (EOL vehicles) é a Diretiva 2000/53/UE (UNIÃO EUROPÉIA, 2000).

\subsection{PRINCIPAIS PROCESSOS DE RECICLAGEM DE MATERIAIS COMPÓSITOS}

\subsubsection{Reciclagem de Materiais Compósitos Poliméricos: Tipos e Conceitos}

A reciclagem dos resíduos poliméricos pode ser classificada em três tipos: primária, secundária, terciária. Incluindo-se a estes três tipos pode-se ter mais uma classificação: a reciclagem quaternária. A reciclagem primária e a secundária são tipos de reciclagem mecânica. A diferença entre elas reside na origem do resíduo polimérico a ser reciclado, fato que será melhor explicado nos próximos tópicos.

A reciclagem primária ou pré-consumo é a recuperação de resíduos efetuada na própria indústria geradora ou por outras empresas transformadoras. Consiste na conversão de resíduos por tecnologias convencionais de processamento em produtos com características de desempenho equivalentes às daqueles produtos fabricados a partir de resinas virgens. Esses resíduos são constituídos por artefatos defeituosos, aparas provenientes dos moldes ou dos setores de corte e usinagem, e 
são limpos, de fácil identificação, não contaminados por impurezas (ROLIM,2000).

A reciclagem secundária ou reciclagem pós-consumo é a conversão de resíduos descartados no lixo. São constituídos pelos mais diferentes tipos de materiais e resinas, com propriedades também diferentes, exigindo uma boa separação, para poderem ser reaproveitados. A separação dos materiais é bastante facilitada com um programa de coleta seletiva do lixo, evitando a contaminação (STESSEL,1996).

Os diferentes materiais podem ser separados uns dos outros por meio da diferença entre as suas propriedades físicas, como a tensão superficial, a solubilidade, características elétricas e a densidade. A densidade, por exemplo, é o método mais comum de separação, no qual alguns tipos de produtos flutuam na água, enquanto outros afundam (MANRICH,1997).

Existem também os métodos mais sofisticados como DSC (do inglês Diferencial Scanning Calorimeter - Calorimetria Exploratória de Varredura) ou IV (Espectroscopia no Infravermelho) que fornecem diversos dados sobre o material a ser reciclado, mas são métodos caros e podem ser inacessíveis devido ao custo de análise.

A reciclagem terciária é também chamada de reciclagem química. É a decomposição dos resíduos de materiais poliméricos, por meio de processos químicos ou térmicos, em petroquímicos básicos como monômeros ou misturas de hidrocarbonetos que servem como matéria-prima em refinarias ou centrais petroquímicas, para a obtenção de produtos nobres de elevada qualidade (HALIWELL,2006).

É importante ressaltar que os materiais obtidos por este processo de reciclagem necessitam de um tratamento dispendioso na purificação final, sendo só indicado para produtos de alto valor econômico. Em consequência disso, existem poucas plantas de reciclagem química em operação no mundo e a maior parte se concentra na Europa, Japão, e Estados Unidos.

A reciclagem quaternária é a reciclagem energética ou a destruição do resíduo por combustão, para obter energia térmica. A reciclagem quaternária difere da incineração pela primeira utilizar os resíduos como combustível na geração de energia elétrica, enquanto a segunda não reaproveita a energia dos materiais. Cabese ressaltar também a diferença da reciclagem quaternária de processos químicos de pirólise. Neste tipo de reciclagem se aproveita o poder calorífico dos materiais que 
serão queimados. A pirólise também faz uso do calor para degradar os diferentes tipos de materiais, mas visa a geração de produtos químicos a partir do material a ser reciclado. Na Europa, Estados Unidos e Japão, é bastante utilizada a injeção de resíduos como combustível em altos fornos de siderurgia, reduzindo bastante (de 70 a 90\%) a massa de material a ser descartado (HALIWELL,2006).

\subsubsection{Reciclagem Mecânica (ou Reciclagem Primária/Secundária)}

\subsubsection{Reciclagem com Separação Parcial de Componentes}

A reciclagem mecânica é uma das peças chave para quase todos os tipos de reciclagem de materiais poliméricos, termofixos ou não, sendo de grande importância para os métodos de reciclagem primária e secundária. Conceitualmente, a reciclagem mecânica é a conversão dos resíduos em grânulos que podem ser reutilizados na produção de outros produtos (WIEBECK,2004).

No exterior, dois exemplos de desenvolvimento em escala industrial que utilizam processos de reciclagem mecânica de forma bastante similar, são a ERCOM (Alemanha), e a Phoenix Fiberglass (Canadá). O processo de reciclagem mecânica começa com a redução de tamanho dos resíduos de compósitos por corte ou quebra, de forma a obter-se peças com tamanhos de 50 a $100 \mathrm{~mm}$. Em seguida, o material é conduzido para moagem em moinhos de martelo, ou outro moinho de alta velocidade, para redução de tamanho até partículas de $10 \mathrm{~mm}$ a $50 \mathrm{~mm}$.

Após as etapas de corte, quebra, e moagem, o material particulado resultante passa por processos de classificação de tamanho, com peneiras e ciclones, de forma no final dos processos obter-se duas fases separadas: uma rica em fibras e outra rica em resina. Na Figura 3, é mostrado o processo de reciclagem realizado pela ERCOM e Phoenix Fiberglass.

Figura 3 - Fluxo do processo de reciclagem mecânica realizado pela ERCOM e Phoenix Fiberglass

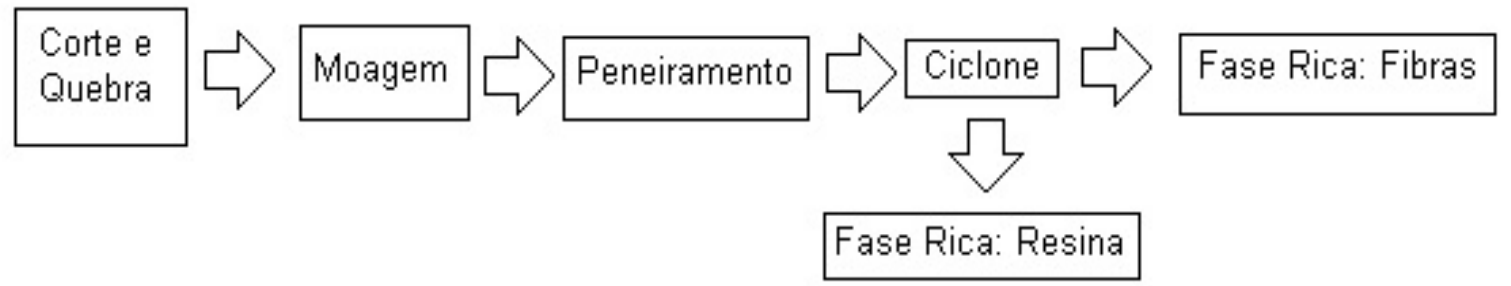

Fonte: Bajpai, 2013. 
Dentre as principais vantagens na utilização deste processo de reciclagem mecânica, têm-se: baixo custo de processamento, com gasto apenas de energia para redução de tamanho e classificação do material; bom controle na emissão de particulados; e ausência de emissão de novos resíduos líquidos ou gasosos como subprodutos do processo de reciclagem. Com relação as principais desvantagens com relação ao uso de reciclagem mecânica, têm-se a completa destruição da fibra, que poderá ser usada apenas em processos mais simples, e de menos exigências técnicas que os processos originais; e geração de grandes quantidades de resíduos de resina que não são consumíveis imediatamente em qualquer tipo de processo de produção de compósitos.

Após o processamento, os materiais estão prontos para serem usados em novos processos de produção de compósitos. A fase rica em resíduos de resina normalmente é direcionada para uso como carga, associada com outros aditivos, de forma a regular propriedades físicas e mecânicas no novo compósito. A fase rica em resíduos de fibras é utilizada em alguns casos na substituição de parte do reforço, bem como carga junto a novas peças de material compósito (YANG,2012).

\subsubsection{Reciclagem Química (ou Reciclagem Terciária)}

\subsubsection{Reciclagem via Extração com Fluidos Supercríticos}

No estado supercrítico, as propriedades físico-químicas de um fluido assumem valores intermediários àqueles dos estados líquido e gasoso. Propriedades relacionadas à capacidade de solubilização, como a densidade de um fluido supercrítico aproximam-se daquelas típicas de um líquido, enquanto que, propriedades relacionadas ao transporte de matéria, como a difusividade e a viscosidade, alcançam valores típicos de um gás.

Sabe-se que os líquidos são excelentes solventes, mas de difusão lenta e 
alta viscosidade. Os gases, por sua vez, são péssimos solventes, mas se difundem com extrema facilidade e são pouco viscosos. Os solventes supercríticos, combinando características desejáveis tanto de líquidos quanto de gases, são ótimos solventes com alta difusividade e baixa viscosidade. Como conseqüência destes atributos, a extração com fluido supercrítico torna-se um processo rápido e eficiente. Por outro lado, as condições para atingir-se um estado supercrítico dependem diretamente do tipo de solvente, sendo necessária a aplicação de altas temperaturas e pressões para que este estado seja atingido (KIRAN,BRENNECKE,2001).

As pesquisas realizadas com fluidos supercríticos são diversas, sobretudo pela diversidade de solventes e a sua potencialidade para a criação de processos seguros e mais limpos quanto a emissão de produtos e sub-produtos do processo de reciclagem. Na Figura 4 segue esquema de processo de extração via fluidos supercríticos.

Figura 4 - Processo de extração via fluidos supercríticos para reciclagem de compósitos

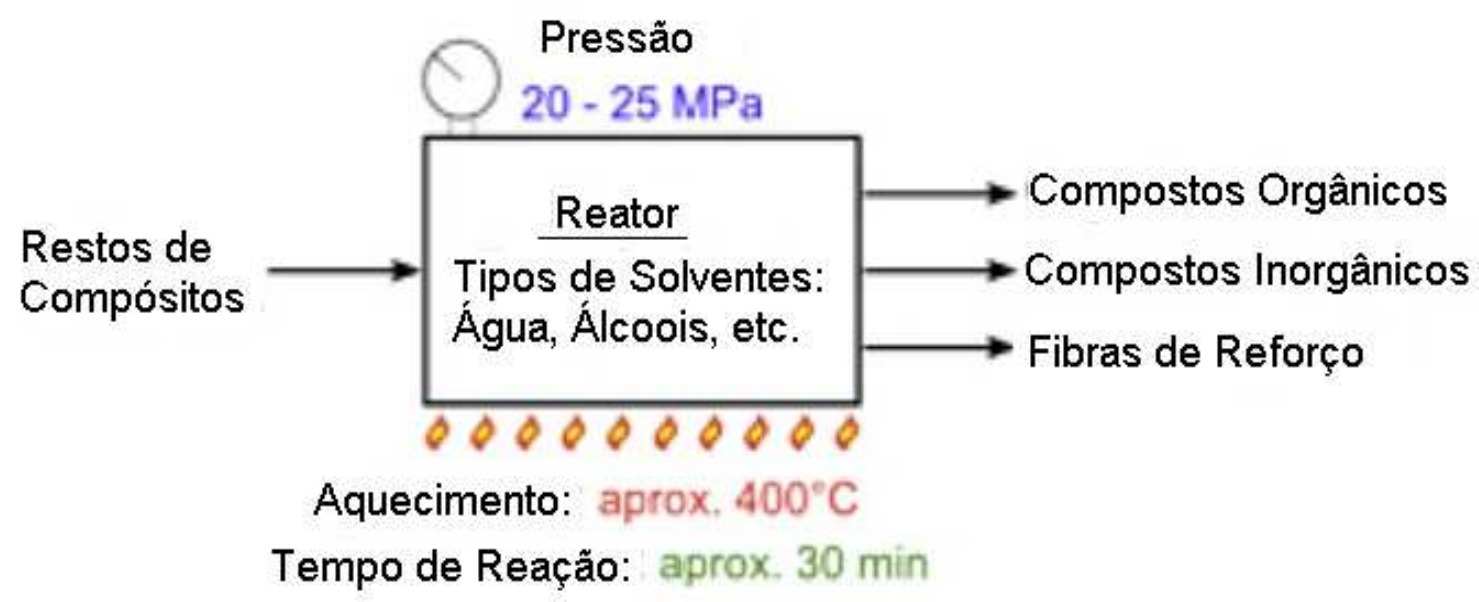

Fonte: Morin et al,2012.

A maior parte dos processos de reciclagem de compósitos com fluidos supercríticos envolve principalmente solventes como água e álcoois (como etanol, propanol e outros). Estes solventes são normalmente escolhidos principalmente devido a sua disponibilidade, e facilidade em serem tratados após processo de reciclagem.

Na Tabela 1 é apresentado o resumo dos principais resultados obtidos em pesquisas realizadas recentemente. 
Tabela 1 - Resultados obtidos para reciclagem de compósitos via extração com fluidos supercríticos.

\begin{tabular}{ll}
\hline Condição Aplicada & Resultados Obtidos \\
\hline - Solvente: água & -Recuperação de fibras limpas. \\
$\mathrm{T}=380^{\circ} \mathrm{C}$ & \\
$\mathrm{P}=25 \mathrm{Mpa}$ & \\
Tempo de Reação: não indicado &
\end{tabular}

- Solvente: água

$\mathrm{T}=400^{\circ} \mathrm{C}$

$\mathrm{P}=29 \mathrm{MPa}$

Tempo de Reação: 30 minutos

- Solvente: água

$\mathrm{T}=260^{\circ} \mathrm{C} / \mathrm{Tempo}$ de Reação=105 min.

$\mathrm{T}=290^{\circ} \mathrm{C} / \mathrm{Tempo}$ de Reação=75 min.

$\mathrm{P}=$ não indicada

Taxa de Alimentação: 1:5 g/mL

- Solvente: água / Excesso de oxigênio $\mathrm{T}=440^{\circ} \mathrm{C}$

$\mathrm{P}=30 \mathrm{MPa}$

Tempo de Reação: 30 minutos

- Solvente: n-propanol

$\mathrm{T}=310^{\circ} \mathrm{C}$

$\mathrm{P}=5,2 \mathrm{MPa}$

Tempo de Reação: 20 minutos

- Solvente: álcoois diversos

$\mathrm{T}$ diversas

$\mathrm{P}=15 \mathrm{MPa}$

Tempo de Reação: 70 minutos
-Sem catalisador alcalino, taxa de decomposição da resina epóxi de 79,3\%, e fibras de carbono recuperadas com perdas na resistência à tração de $2 \%$;

-Com catalisador alcalino, taxa de decomposição da resina epóxi de 95,4\%, e fibras de carbono recuperadas com perdas na resistência à tração de 10\%;

-Fibras recuperadas com boas propriedades mecânicas (perda de menos de $1,8 \%$ na resistência à tração).

-Decomposição de resina epóxi: 94-97\%;

-Fibras de carbono recicladas com ótimas propriedades mecânicas e superficiais.

-Fibras de carbono recicladas com ótimas propriedades mecânicas e superficiais.

-Sem catalisador alcalino e $\mathrm{T}=350 \stackrel{\circ}{\mathrm{C}}$, taxa de decomposição da resina epóxi: $96.5 \%$;

-Com catalisador alcalino ( $\mathrm{KOH}, 0.02 \mathrm{~mol} / \mathrm{L})$, e $\mathrm{T}=275^{\circ} \mathrm{C}$, taxa de decomposição da resina epóxi: 98\%; e

-Fibras de carbono recuperadas limpas, com perdas na resistência à tração de $1-15 \%$

Fonte: Morin et al,2012, Okajima et al,2002, Pinero-hernanz et al,2008 , Jiang et al, 2009 , Pinerohernanz et al 2008b, Liu et al, 2009 e Bai,2010.

\subsubsection{Reciclagem via Pirólise}

A principal vantagem existente para a aplicação de processos de tratamento via pirólise é a ausência do uso de solventes para a realização do processo. É um processo bastante interessante, pois permite que todo o tipo de resíduo permaneça confinado dentro do reator, permitindo que as diferentes frações gasosas, líquidas e gasosas sejam extraídas de maneira controlada. Para compósitos, devida à variabilidade de processos de fabricação, cargas e aditivos presentes, o processo de pirólise é uma boa opção também por sua versatilidade e aplicação.

Estudos realizados pela Universidade de Leeds (Inglaterra), e pela Escola 
de Engenharia de Bilbao (Espanha), de forma independente, apresentaram bons resultados para a reciclagem de materiais compósitos. Em linhas gerais, os processos estudados por ambas entidades seguem o fluxograma mostrado na Figura 5.

Figura 5 - Fluxograma de processo de reciclagem via pirólise.

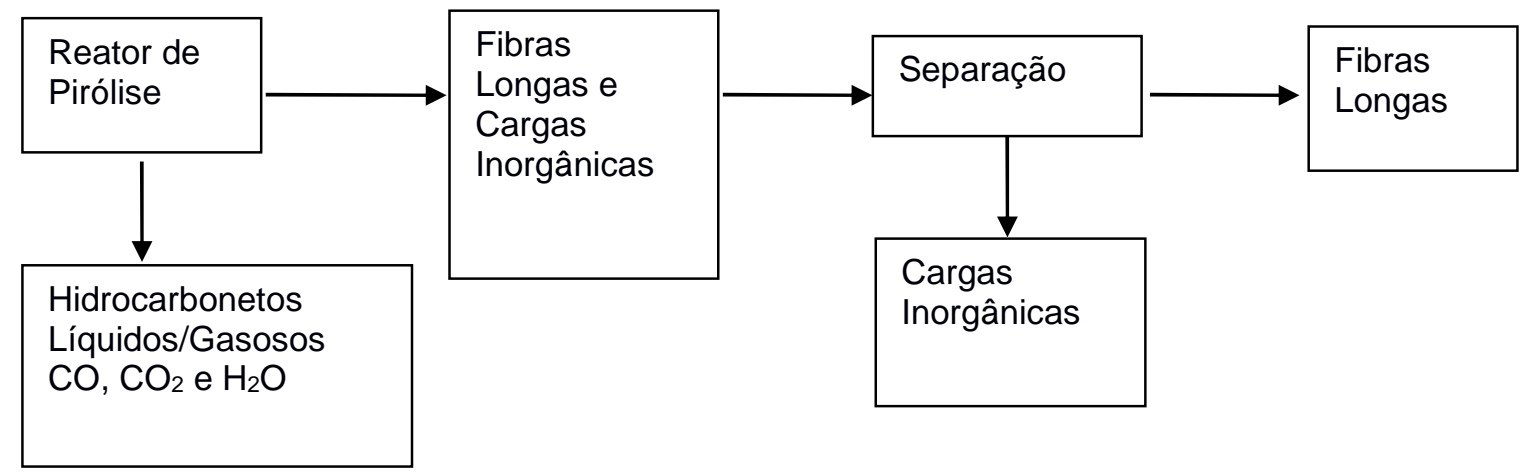

Fonte: Torres et al, 2009.

Os estudos realizados pela Escola de Engenharia de Bilbao concentraram-se no tratamento de resíduos de material compósito produzido a partir de fibra de vidro e resinas poliéster. A faixa de temperatura adotada para a realização dos testes foi de 300 a $700 \stackrel{\circ}{\circ}$, não sendo obtidos resultados satisfatórios para temperaturas inferiores a $400 \stackrel{\circ}{\circ}$. As fibras foram separadas sem maiores problemas, sendo obtida uma concentração de componentes pós-pirólise conforme apresentado na Tabela 2.

Tabela 2 - Concentração de produtos obtidos após processo de pirólise

\begin{tabular}{lllll}
\hline Temperatura (ํㅜ) & $\mathbf{4 0 0}$ & $\mathbf{5 0 0}$ & $\mathbf{6 0 0}$ & $\mathbf{7 0 0}$ \\
\hline Fração Sólida & 75,2 & 74,9 & 73,9 & 72,6 \\
Fração Líquida & 14,5 & 14,2 & 14,9 & 13,7 \\
Fração Gasosa & 10,5 & 11,0 & 11,5 & 12,8 \\
\hline
\end{tabular}

Para referência: material compósito original a base de fibra de vidro e poliéster com $28,3 \%$ de resina, $25 \%$ de fibra de vidro, e $46,7 \%$ de cargas inorgânicas (carbonato de cálcio).

Fonte: Torres et al, 2009.

A fração gasosa obtida contém, sobretudo $\mathrm{CO}_{2}$, $\mathrm{CO}$, e menos de $10 \%$ de gases a base de hidrocarbonetos com baixo poder calorífico. A fração líquida obtida contém uma mistura complexa de compostos orgânicos contendo cerca de $66 \%$ de compostos aromáticos, e cerca de $25 \%$ de compostos oxigenados, como cetonas, ácidos carboxílicos, com poder calorífico similar ao do óleo combustível. Por fim, a fração sólida é composta em sua maior parte pela fibra de vidro e cargas inorgânicas 
residuais, e uma pequena fração de material não degradado (TORRES et al, 2009).

Outros estudos realizados pela Universidade de Leeds buscaram uma abordagem mais ampla. Foram testados compósitos a base de resina poliéster, viniléster, epóxi, e fenólica. A faixa de temperatura adotada nos testes foi de 350 a 800 ${ }^{\circ} \mathrm{C}$, sendo que em $450{ }^{\circ} \mathrm{C}$ toda a resina poliéster foi degradada, e na faixa de 500 a $550 \stackrel{\circ}{ } \mathrm{C}$ todas as demais resinas estudadas foram degradadas. Na Tabela 3, são apresentados os resultados obtidos para alguns tipos de compósitos.

Tabela 3 - Concentração das frações de produtos obtidos via pirólise, para tipos de compósitos

\begin{tabular}{|c|c|c|c|c|}
\hline Compósito & Temp. (으) & Fração Sólida (\%) & Fração Líquida (\%) & Fração Gasosa (\%) \\
\hline $\begin{array}{l}\text { Resina Poliéster } \\
\text { com Fibra de Vidro } \\
\text { e } \quad \text { Cargas } \\
\text { Inorgânicas }\end{array}$ & 500 & 45,8 & 45,7 & 8,5 \\
\hline $\begin{array}{l}\text { Resina Fenólica } \\
(24 \%) \text { com Fibra } \\
\text { de Vidro e Cargas } \\
\text { Inorgânicas }\end{array}$ & 500 & 90,2 & 8,8 & 1,0 \\
\hline $\begin{array}{l}\text { Resina Epóxi com } \\
\text { Fibra de Carbono }\end{array}$ & 500 & 67,4 & 31,3 & 1,2 \\
\hline $\begin{array}{l}\text { Resina Poliéster } \\
(70-80 \%) \quad \text { com } \\
\text { Fibra de Vidro }\end{array}$ & 550 & 30,0 & 59,4 & 10,6 \\
\hline $\begin{array}{l}\text { Resina Vinil-éster } \\
(30 \%) \text { com fibra de } \\
\text { vidro }\end{array}$ & 550 & 83,4 & 15,0 & 1,6 \\
\hline
\end{tabular}

As diferentes frações sólidas obtidas para cada tipo de compósito devemse principalmente ao conteúdo de fibras e cargas inorgânicas. Com relação as frações líquida e gasosa, os produtos obtidos foram similares aos obtidos pelo estudo da Escola de Engenharia de Bilbao, com algumas diferenças quanto à capacidade calorífica e composição das frações líquidas. Em ambas pesquisas apresentadas, é possível obter-se as cargas inorgânicas e fibras de vidro e carbono para uso em outros processos, conforme o caso. Cabe ressaltar apenas que as fibras resultantes, de modo geral, sofrem perdas em suas propriedades mecânicas na ordem de $50 \%$, sendo necessário criterioso estudo para a sua aplicação em novos compósitos (TORRES et al, 2009 e PICKERING,2006). 


\subsubsection{Reciclagem via Pirólise com Catalisadores / Vácuo}

A empresa americana Adherent Technologies Inc. (ATI) desenvolveu o processo para a reciclagem de materiais compósitos à base de fibra de carbono e resina epóxi utilizando-se de um reator com capacidade para pirólise catalítica e pirólise a vácuo, ou quaisquer combinações de ambos os processos. A aplicação original de seu processo era direcionada para a aplicação em tratamento de resíduos sólidos em embarcações militares de grande porte (porta-aviões, entre outros).

Em face da eficiência apresentada pelo processo para os mais diferentes tipos de resíduos, o reator foi empregado para o tratamento de compósitos, também obtendo êxito com este tipo de material (GOSAU,2010).

Na Figura 6 é mostrado um esquema resumido do processo da ATI.

Figura 6 - Processo de reciclagem da ATI para tratamento de resíduos

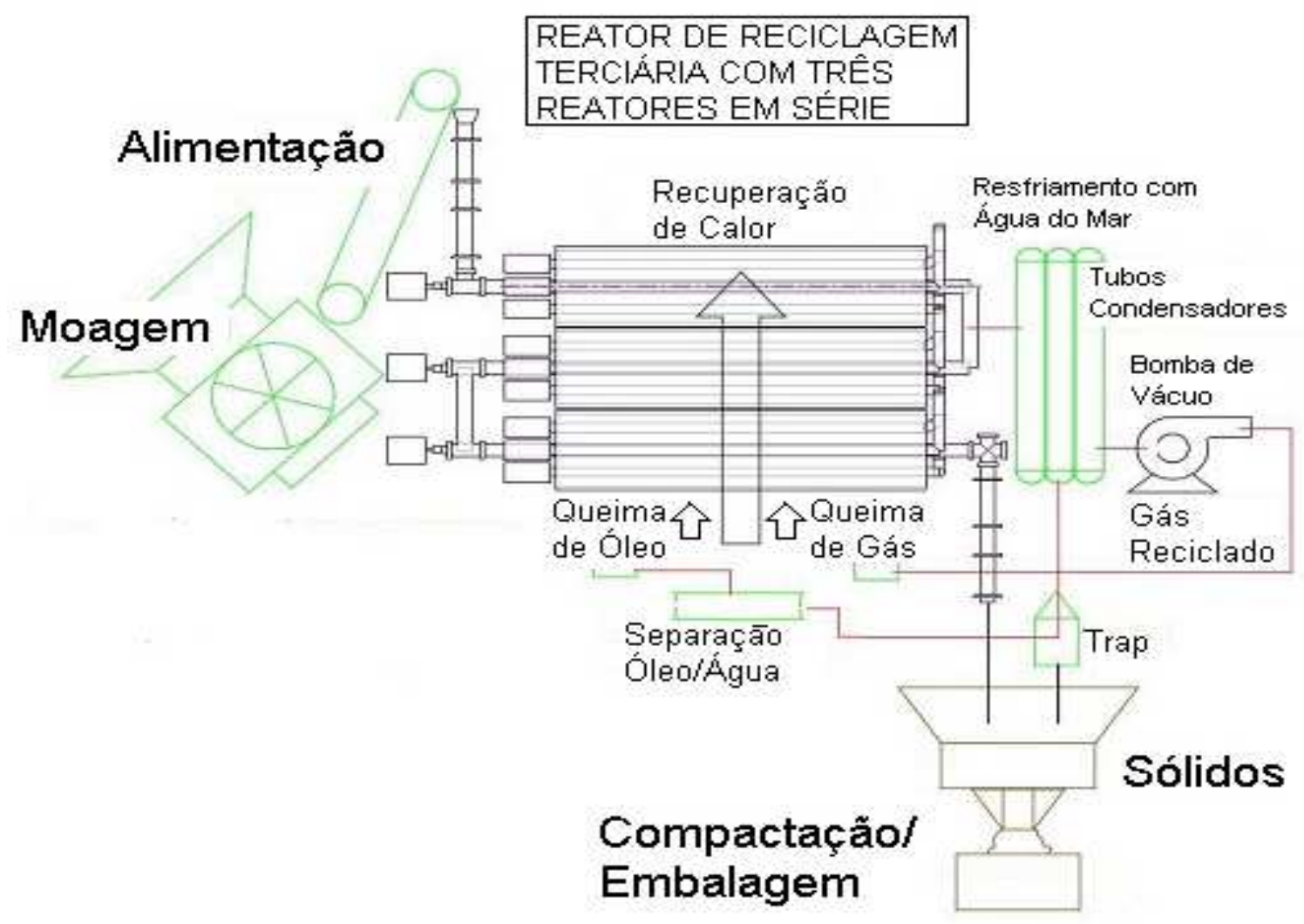

Fonte: Gosau,2010.

Inicialmente, todo material a ser reciclado é triturado em pequenas partes com $10 \mathrm{~cm}$ de comprimento. Após a trituração, o material é alimentado no reator e 
aquecido até a condição de operação desejada. Como o sistema proporciona dois tipos de tratamento em uma única unidade, a qualidade do produto final é definida pela necessidade do uso de cada um dos tipos de pirólise disponíveis.

A pirólise catalítica ocorre a baixas temperaturas $\left(200^{\circ} \mathrm{C}\right)$ na presença de um catalisador específico (não divulgado), permitindo a decomposição da resina epóxi presente em hidrocarbonetos líquidos e gasosos, de baixo massa molecular. A fibra de carbono é recuperada praticamente sem sofrer degradação em suas propriedades mecânicas, com boa interface para a produção de novos compósitos.

A pirólise a vácuo é utilizada em temperaturas na ordem de $500 \stackrel{\circ}{\circ}$ e permite recuperar resina e fibras de carbono. Em comparação com o processo de pirólise catalítica, as fibras de carbono recicladas obtidas por este processo ainda permanecem com um pouco de resíduo em sua superfície. De forma a retirar este resíduo superficial, a ATI combina ambos os processos, para se obter um material reciclado de melhor qualidade.

Resumidamente, a primeira parte do seu processo consiste em remover a maior parte da resina e alguns contaminantes. A resina restante é então eliminada por tratamentos térmicos complementares para a produção de fibra de pureza de $99 \%$ com uma perda de apenas 5\% em suas propriedades mecânicas (MORIN et al,2012).

\subsubsection{Reciclagem via Solvólise}

A reação de solvólise utiliza solventes como água, álcool, amônia ou glicol para quebrar as ligações químicas da resina (epóxi, fenólica, poliéster, entre outras) que atua como matriz em compósitos. Os produtos finais do processo são sólidos, na forma de fibras e cargas inorgânicas, e líquidos, constituídos de uma mistura de monômeros orgânicos e de reagentes em excesso (Figura 7).

Figura 7 - Esquema de processo de solvólise para reciclagem de materiais compósitos

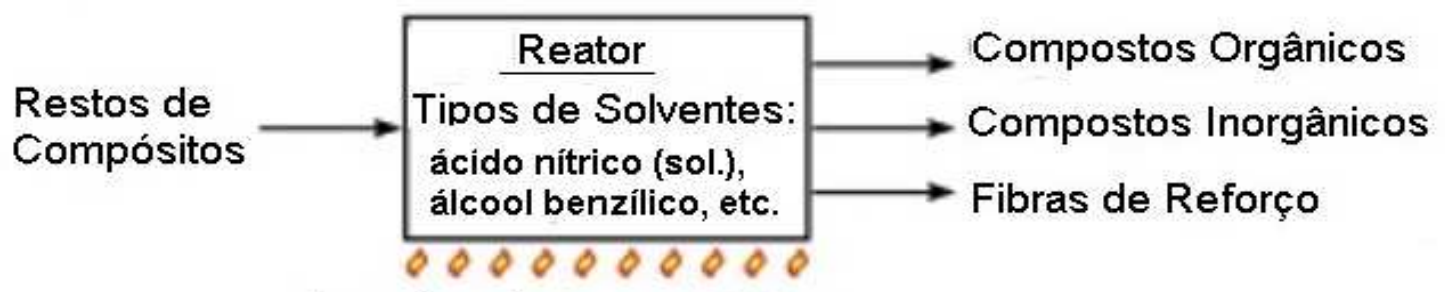

Aquecimento:

Tempo de Reação: Poucas Horas

Fonte: Morin et al,2012. 
A decomposição de material compósito a base de fibra de carbono e epóxi utilizando-se de um processo de solvólise à temperatura baixa foi investigada por diversos pesquisadores.

Experiências realizadas em um reator de vidro (com um diâmetro de 100 $\mathrm{mm}$ e um comprimento de $300 \mathrm{~mm}$ ) a uma temperatura de $90{ }^{\circ} \mathrm{C}$, com uma concentração de ácido nítrico solução de $8 \mathrm{M}$ e uma proporção de massa amostra/solução de ácido nítrico de $60 \mathrm{~g}: 1 \mathrm{~L}$. Nessas condições de operação, a resina epóxi foi decomposta em frações de baixo massa molecular, e as fibras foram recuperadas intactas com a perda de propriedades mecânicas da ordem de 1,1\%.

Outros experimentos foram realizados em um reator com sistema de recirculação de solução, também fazendo uso de ácido nítrico e aquecimento. As melhores condições para a decomposição da resina epóxi foram as seguintes: solução aquosa de ácido nítrico $12 \mathrm{M}$, com temperatura de $90^{\circ} \mathrm{C}$, um fluxo de recirculação de solução de $1,0 \mathrm{~cm} / \mathrm{s}$, e um tempo de decomposição de 6 horas. Nessas condições, as fibras de carbono recicladas obtidas foram limpas, apresentando poucos resíduos, e uma pequena perda de resistência à tração de 2,9\%.

Em comparação com os métodos que fazem uso de leito fluidizado e de processos de pirólise a baixas temperaturas, o processo de solvólise é mais eficiente uma vez que se recupera todos os produtos químicos presentes, desde a matriz polimérica até as fibras de carbono. Apesar disso, alguns solventes podem ser agressivos e, por vezes, tóxicos para o meio ambiente, sendo necessários cuidados com relação aos subprodutos gerados pelo processo de reciclagem, conforme for o caso (MORIN et al, 2012).

\subsubsection{Reciclagem via Irradiação com Micro-ondas}

O tratamento de resíduos compósitos via aplicação de micro-ondas consiste no aquecimento do material de dentro para fora, proporcionando a degradação da resina existente deixando as fibras de carbono limpas para reutilização em aplicações de qualidade alta. Em linhas gerais, o processo com aplicação de micro-ondas segue a sequência de etapas mostradas na Figura 8. 
Figura 8 - Processo de reciclagem com irradiação via micro-ondas

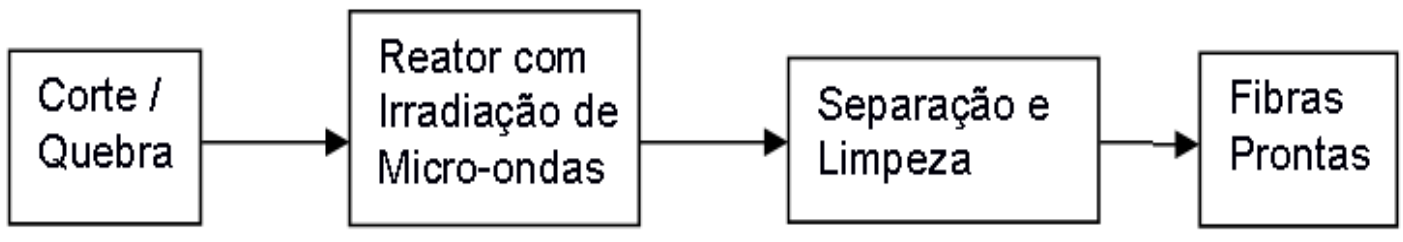

Fonte: Daimlerchrysler,2000.

A principal diferença existente entre os processos que fazem uso de radiação de micro-ondas é o meio reacional onde é colocado o material compósito para o tratamento. Alguns pesquisadores fazem o uso de solventes auxiliares, de forma a aumentar a eficiência de degradação, e ao mesmo tempo, efetuar um tratamento mais eficiente das fibras. Assim, logo após sair do reator as fibras necessitam apenas de uma nova limpeza para retirada de reagentes residuais. Por outro lado, outros autores fazem uso de reatores a vácuo, sem uso de solventes, utilizando-se apenas de calor para o processo de reciclagem, efetuando a separação e limpeza finais, se necessários, posteriormente.

Bons resultados foram obtidos fazendo-se o uso de radiação de microondas na faixa de 2 a $3 \mathrm{GHz}$, em uma solução com solventes polares, para a degradação de compósitos. Uma peça de fibra de carbono e resina epóxi, com cerca de $1 \mathrm{~cm}^{2}$, em uma solução $48 \%$ em $\mathrm{H}_{2} \mathrm{SO}_{4}$, com a programação mostrada na Figura 9, foi dissolvida com rendimento superior a $95 \%$ em massa (DAIMLERCHRYSLER,2000).

Figura 9 - Irradiação por Micro-ondas de Solução para Degradação de Resina Epóxi

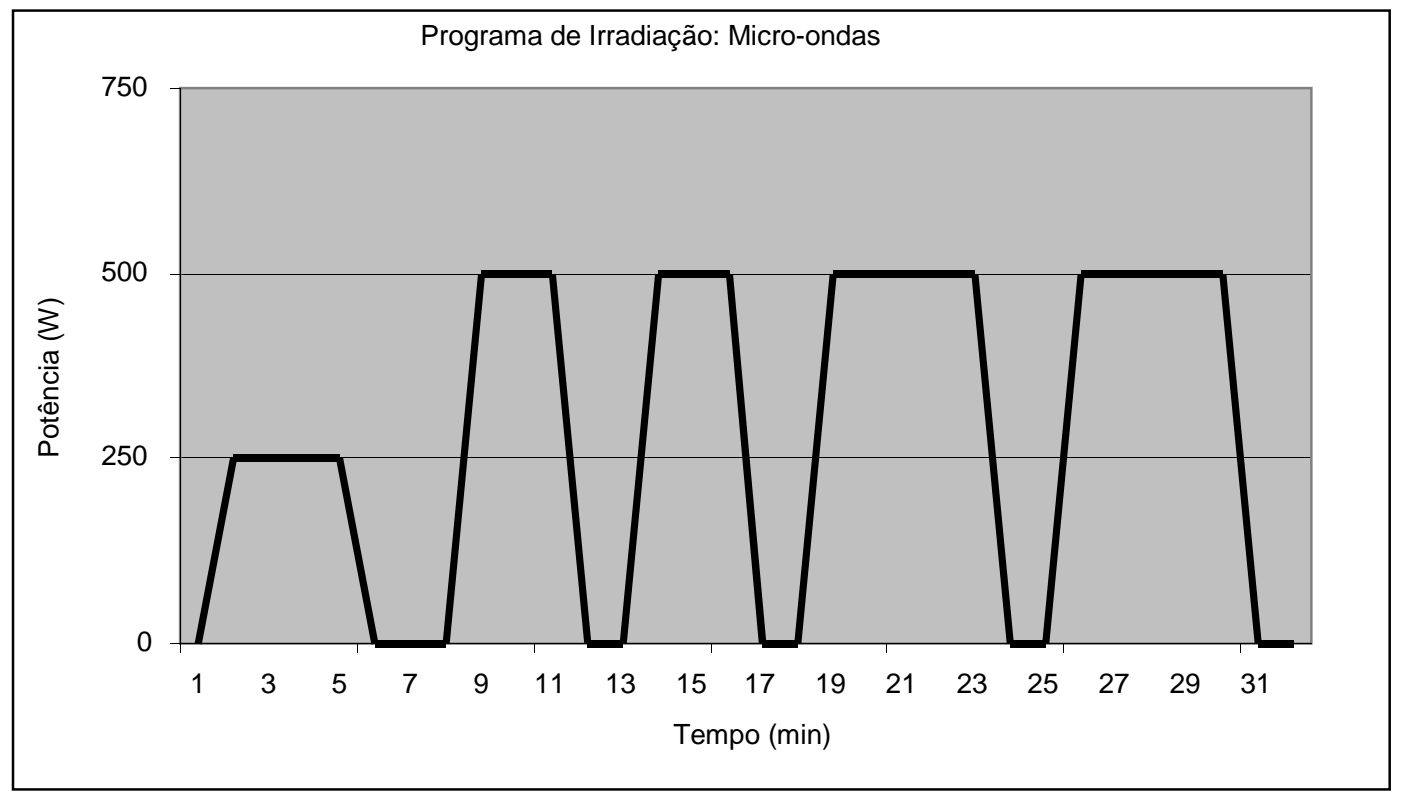

Fonte: Daimlerchrysler,2000. 
Um estudo foi realizado para a reciclagem de fibras de carbono a partir de materiais compósitos poliméricos utilizando uma cavidade de micro-ondas multimodo alimentado a $3 \mathrm{~kW}$ por $8 \mathrm{~s}$. Por meio deste trabalho não foram utilizados solventes, efetuando-se a variação da frequência de trabalho do sistema para completa degradação da resina presente e quaisquer outros subprodutos. O produto final obtido manteve suas propriedades mecânicas e superficiais podendo ser utilizado em outros tipos de compósito. No entanto, apesar do sucesso obtido, mais pesquisas serão necessárias, a fim de determinar se este processo é viável economicamente.

A infraestrutura para operação de sistemas via irradiação com micro-ondas é diferenciada, sendo necessária a determinação de propriedades físicas pouco usuais, como constante dielétrica, permeabilidade magnética, entre outras. Estas propriedades também apresentam variações para a frequência de operação e temperatura do material irradiado com micro-ondas (LESTER,2004).

\subsubsection{Reciclagem Térmica (ou Reciclagem Quaternária)}

\subsubsection{Reciclagem com Separação de Fibras de Reforço}

Em processos de reciclagem térmica ou quaternária, o resíduo é queimado, podendo a energia liberada ser utilizada no processo de reciclagem, ou transformada em uma outra forma de energia (energia elétrica, por exemplo).

No processo apresentado a seguir, pesquisado pela Universidade de Nottingham (Inglaterra), e pela Universidade de Hamburgo (Alemanha), a energia liberada da queima de resinas termofixas é usada como fonte de calor para a separação das fibras, possibilitando reciclagem de energia pela combustão da resina, e de parte do material compósito pela reciclagem das fibras de reforço.

$\mathrm{Na}$ Figura 10 é mostrado um fluxograma de processo resumido.

Figura 10 - Esquema simplificado de Reciclagem Térmica com reaproveitamento de fibras.

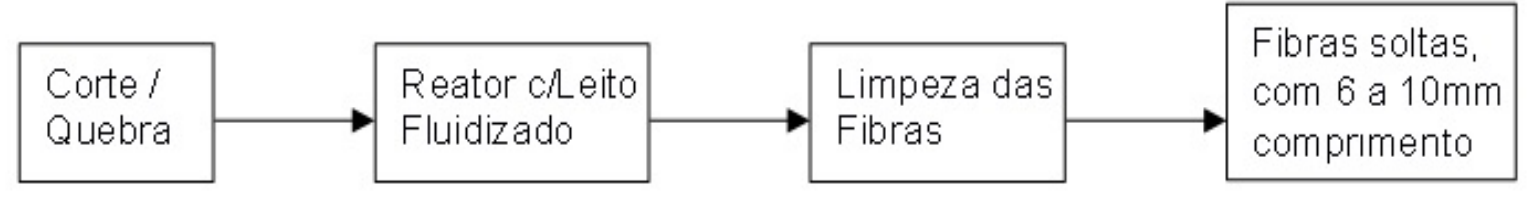

Fonte: Pickering, 2006. 
Os resíduos de compósito são primeiramente cortados e quebrados em partes com até $25 \mathrm{~mm}$ de comprimento, antes de serem alimentados em um reator com leito fluidizado. O reator é operado com um leito em areia, e é pré-aquecido com ar para facilitar o início do processo. Para resíduos com resinas poliéster, o reator é aquecido a $450 \stackrel{\circ}{\mathrm{C}}$, sendo aquecido até $550 \stackrel{\circ}{\mathrm{C}}$ para resíduos com resinas epóxi (YANG,2012).

As fibras obtidas são limpas, possuem um comprimento de 6 a $10 \mathrm{~mm}$, e sofrem perdas com relação a suas propriedades originais. Para o caso de fibras de vidro, é observada uma redução em $50 \%$ na resistência à tração, enquanto para fibras de carbono a perda é um pouco menor, com perda de $20 \%$ em tenacidade.

As pesquisas realizadas pela Universidade de Nottingham permitiram a obtenção de fibras de melhor qualidade. Fibras com comprimento médio até $10 \mathrm{~mm}$ mantiveram cerca de $75 \%$ de sua resistência à tração, enquanto o módulo de Young permaneceu inalterado quando comparado com fibras originais. Na Figura 11, é mostrado o processo conforme estudado pela Universidade de Nottingham.

Figura 11 - Processo de reciclagem térmica estudado pela Universidade de Nottingham

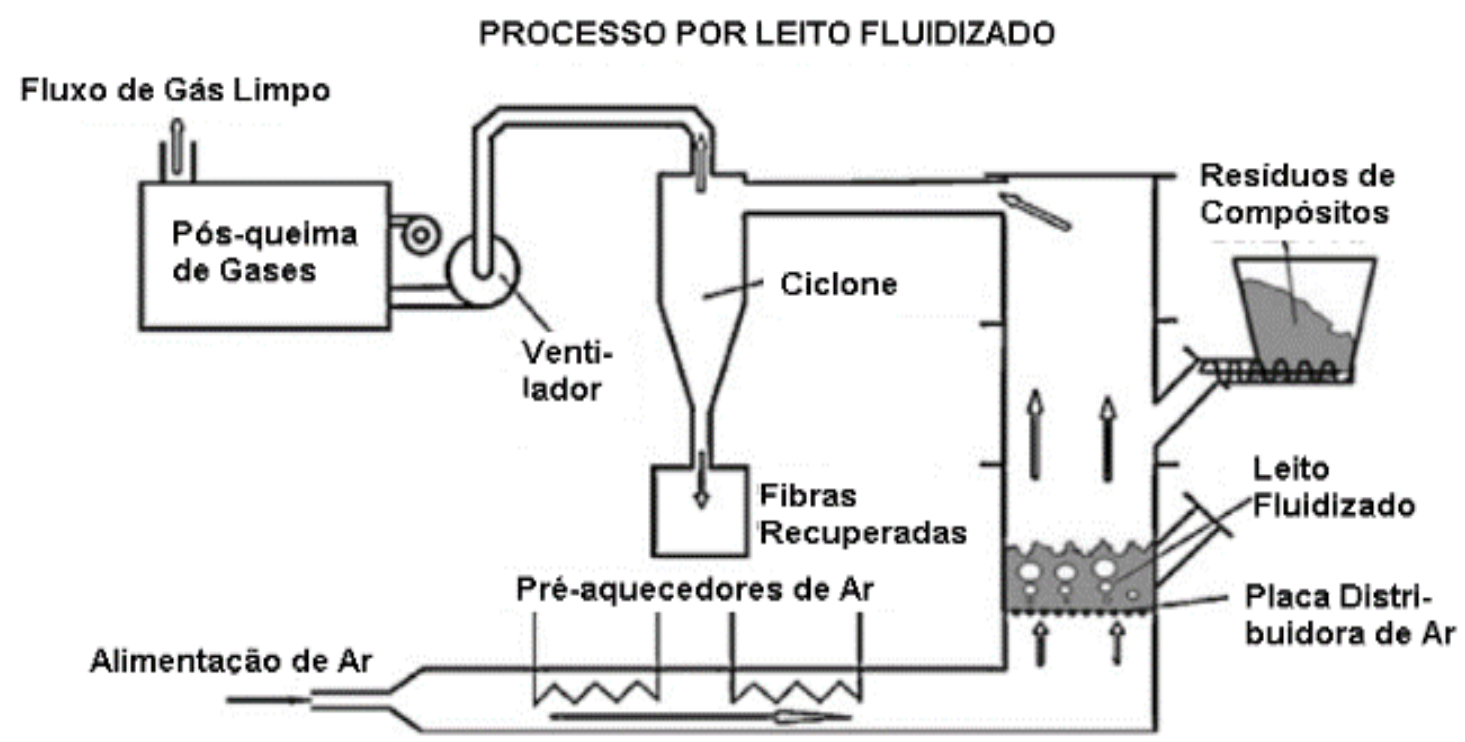

Fonte: Pickering, 2006. 
O uso do processo de reciclagem térmica permite o fornecimento de fibras que podem ser usadas em processos de laminação manual. A viabilidade econômica também foi estudada, e para que os custos envolvidos se tornem comercialmente interessantes, é necessária a reciclagem de 10.000 toneladas/ano de resíduos de compósitos a base de fibra de vidro. Para fibras de carbono, o volume mínimo para viabilidade comercial pode ser menor, face ao maior valor agregado destas fibras. Adicionalmente, questões como qualidade e preço ainda também determinam o consumo do material reciclado, e ainda são as principais barreiras para uso em novos compósitos (PICKERING, 2006).

\subsubsection{Reciclagem para Uso em Fabricação de Cimento}

$\mathrm{Na}$ Europa, devido às diversas regulações ambientais vigentes, indústrias produtoras de determinados tipos de compósitos de grande massa e volume (como pás eólicas, tanques de combustível, entre outros) têm se reunido para a formação de diferentes projetos e iniciativas para implementação de sistemas de logística reversa e reciclagem de seus produtos. $\mathrm{Na}$ área de reciclagem térmica, a reunião das empresas Fiberline (Dinamarca), Zayons (Alemanha) e Holcim (Alemanha) gerou o Compocycle, um processo de reciclagem de material compósito a base de fibra de vidro em fábricas de cimento para uso de material compósito como combustível e matéria-prima. O processo Compocycle funciona conforme mostrado resumidamente na Figura 12.

Figura 12 - Processo de reciclagem de compósitos a base de fibra de vidro Compocycle

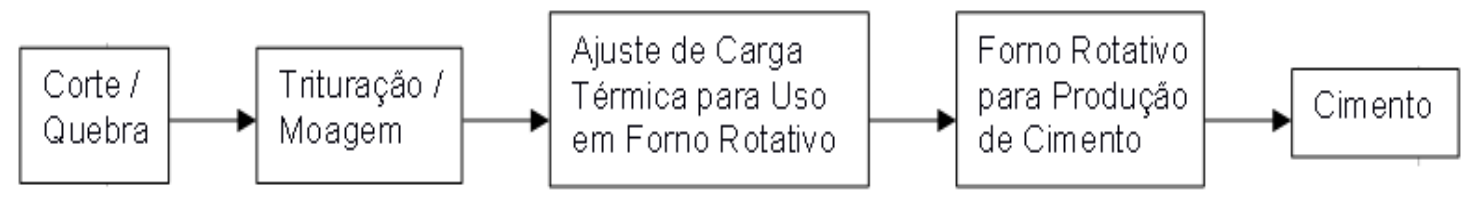

Fonte: Fiberline,2019.

A empresa Fiberline, fabricante de pás eólicas para aerogeradores, recebe as pás eólicas usadas, bem como outras partes de sistemas aerogeradores compostas de fibra de vidro, fibra de carbono, e resina poliéster, e providencia o corte 
e quebra em partes menores, para facilitar o transporte até as instalações da Zayons. Resíduos de processo de fabricação, como restos de fibras e resinas, peças defeituosas, também são encaminhados nesta etapa.

$\mathrm{Na}$ Zayons, o material recebido é triturado e moído. Após a redução de tamanho das peças recebidas, é realizado o ajuste de carga térmica do material, de forma que a capacidade calorífica da carga de reciclado esteja adequada para uso em fornos para fabricação de cimento. $O$ ajuste é feito com a adição de outros tipos de materiais e combustíveis, de forma que o material possa ser alimentado e liberar a quantidade de energia adequada. Após o ajuste realizado pela Zayons, o material é encaminhado para a Holcim, onde será alimento em fornos rotativos para a produção de cimento.

A empresa Holcim recebe o material pronto para uso. Dessa forma a resina termofixa presente é usada como parte do combustível para operação do forno. As frações inorgânicas, como a fibra de vidro triturada e outras cargas inorgânicas, são usadas na substituição de óxido de silício e outras matérias-primas consumidas na fabricação de cimento. Ao final do processo, a empresa Holcim, a cada 1000 toneladas de material compósito consumido, realiza uma economia de energia e matéria-prima equivalente a 400 toneladas de carvão, 200 toneladas de carbonato de cálcio, 200 toneladas de óxido de silício, e 150 toneladas de óxido de alumínio. Cabe ressaltar também que em face das regulações impostas pela UE, não são liberadas quaisquer quantidades de poeira, cinzas, ou outros tipos de particulados. Assim, todo resíduo de compósitos produzido pela Fiberline é transformado em energia e matériaprima, não sendo encaminhados quaisquer resíduos para aterros industriais(FIBERLINE,2019).

\subsection{CONCEITOS SOBRE MICRO-ONDAS E APLICAÇÕES}

\subsubsection{Introdução}

As micro-ondas formam uma parte do espectro eletromagnético contínuo que se estende de baixas frequências até radiações de maior energia, como raios 
cósmicos, conforme apresentado na Tabela 4 (KU et al,2002).

Tabela 4 - Espectro eletromagnético

\begin{tabular}{lcc}
\hline \multicolumn{1}{c}{ Região } & Frequência $\mathbf{( H z )}$ & Comprimento de onda \\
\hline Frequências de áudio & $30-30^{*} 10^{3}$ & Maior que $10 \mathrm{~km}$ \\
Frequências de rádio & $30 * 10^{3}-30^{*} 10^{11}$ & $10 \mathrm{~km}-1 \mathrm{~mm}$ \\
Infravermelho & $3^{*} 10^{11}-4,1{ }^{*} 10^{14}$ & $1 \mathrm{~mm}-730 \mathrm{~nm}$ \\
Visível & $4,1^{*} 10^{14}-7,5^{*} 10^{14}$ & $730 \mathrm{~nm}-400 \mathrm{~nm}$ \\
Ultravioleta & $7,5{ }^{*} 10^{14}-10^{17}$ & $400 \mathrm{~nm}-0,3 \mathrm{~nm}$ \\
Raios- $X$ & Maior que $10^{17}$ & Menor que $3 \mathrm{~nm}$ \\
Raios gama & Maior que $10^{20}$ & Menor que $3 \mathrm{~nm}$ \\
Raios cósmicos & Maior que $10^{20}$ & Menor que $3 \mathrm{~nm}$ \\
\hline
\end{tabular}

Fonte: Ku et al,2002.

Nesta faixa de frequências, as frequências de rádio se dividem em bandas, como é apresentado na Tabela 5. As bandas 9, 10, e 11 constituem a faixa de frequências de micro-ondas, que são limitadas nas baixas frequências pela banda de VHF (very high frequencies), e nas altas frequências pela banda de infravermelho próximo. Assim, por suas características, as micro-ondas propagam-se pelo vácuo a velocidade da luz, como qualquer outro tipo de radiação do espectro eletromagnético, na faixa de frequências de $300 \mathrm{MHz}$ até $300 \mathrm{GHz}$ (KU et at,2002).

Tabela 5 - Bandas de frequência

\begin{tabular}{llc}
\hline Banda & Denominação & $\begin{array}{c}\text { Limites de } \\
\text { Frequência }\end{array}$ \\
\hline 4 & Frequências muito baixas - Very low frequences (VLF) & $3-30 \mathrm{kHz}$ \\
5 & Frequências baixas - Low frequences (LF) & $30-300 \mathrm{kHz}$ \\
6 & Frequências médias - Medium frequences (MF) & $300-3 \mathrm{MHz}$ \\
7 & Frequências altas - High frequences (HF) & $3-30 \mathrm{MHz}$ \\
8 & Frequências muito altas - Very high frequences (VHF) & $30-300 \mathrm{MHz}$ \\
9 & Frequências ultra altas - Ultra high frequences (UHF) & $300-3 \mathrm{GHz}$ \\
10 & Frequências super altas - Super high frequences (SHF) & $3-30 \mathrm{GHz}$ \\
11 & Frequências extremamente altas - Extremely high frequences (EHF) & $30-300 \mathrm{GHz}$ \\
\hline
\end{tabular}

Fonte: Ku et al,2002.

As micro-ondas, assim como as demais frequências do espectro que são usadas em telecomunicações (para celulares, televisões, radares, entre outras) foram regulamentadas por organismos internacionais, sendo designado o seu uso para fins industriais, científicos e médicos (ISM - Industrial, Scientific, and Medical applications). As frequências regulamentadas encontram-se na Tabela 6 (KU et al,2002). 
Tabela 6 - Bandas ISM

\begin{tabular}{cc}
\cline { 2 - 3 } Banda & Freqüência Central \\
\cline { 2 - 3 } $433,05-434,97 \mathrm{MHz}$ & $433,92 \mathrm{MHz}$ \\
$902-928 \mathrm{MHz}$ & $915 \mathrm{MHz}$ \\
$2400-2500 \mathrm{MHz}$ & $2450 \mathrm{MHz}$ \\
$5725-5875 \mathrm{MHz}$ & $5800 \mathrm{MHz}$ \\
$24-24,25 \mathrm{GHz}$ & $24125 \mathrm{GHz}$ \\
$61-61,5 \mathrm{GHz}$ & $61,25 \mathrm{GHz}$ \\
$122-123 \mathrm{GHz}$ & $122,5 \mathrm{GHz}$ \\
$244-246 \mathrm{GHz}$ & $245 \mathrm{GHz}$ \\
\hline
\end{tabular}

Fonte: Ku et al,2002.

Quanto às aplicações, as frequências de micro-ondas são classificadas em: $915 \pm 25 \mathrm{MHz}$ para as aplicações industriais, $2450 \pm 13 \mathrm{MHz}$ para as científicas e 5800 \pm 75 e $24125 \pm 125 \mathrm{MHz}$ para a área médica (PECORARO,1997).

\subsubsection{Histórico}

O uso de micro-ondas como uma fonte de aquecimento decorreu de uma outra invenção surgida durante a Segunda Guerra Mundial: o RADAR ("Radio Detection And Ranging). Cientistas britânicos desenvolveram um dispositivo que gerava micro-ondas, conhecido como magnétron, que era o coração do RADAR. Em face de dificuldades técnicas e de produção na Inglaterra, eles foram buscar apoio nos EUA, de forma que pudessem usar o parque industrial americano para produzir o magnétron, imprescindível para equipar o sistema de defesa de seu país contra os ataques aéreos alemães.

Após um breve contato com o MIT (Massachusetts Institute of Technology), ocorreu um encontro dos cientistas britânicos com o engenheiro Percy L. Spencer, de uma pequena companhia chamada Raytheon. Após uma análise do projeto britânico, foram propostas mudanças no projeto original, tornando-o mais fácil de produzir e mais eficiente. Os britânicos aceitaram as alterações, de forma que ao final da guerra, a Raytheon foi responsável pela fabricação de $80 \%$ dos magnétrons produzidos, tornando-se em seguida uma gigante do setor de eletrônica e telecomunicações. $O$ uso de micro-ondas como fonte de aquecimento foi o passo seguinte.

Os cientistas britânicos tinham conhecimento de que a operação dos magnétrons gerava micro-ondas e também calor, mas foi Spencer que percebeu que 
poderia usar-se a radiação eletromagnética para o aquecimento de alimentos. Em 1945, Spencer notou que uma barra de doce em seu bolso derreteu quando ele ficou a frente de um magnétron ligado. Intrigado com o ocorrido, em seguida ele realizou uma série de experimentos com outros alimentos, resultando no ano seguinte, 1946, no depósito da primeira patente de um forno para aquecer alimentos a partir do uso de micro-ondas. Em 1947, a Raytheon comercializava o primeiro forno de micro-ondas comercial (SANSEVERINO,2002).

Estudos para o processamento de polímeros via micro-ondas no começo dos anos de 1960 conduziram a diversas aplicações de sucesso em borrachas, em materiais têxteis, e na indústria de alimentos. O primeiro emprego de irradiação de micro-ondas associada a polímeros foi descrita em 1968, com a cura de resinas epóxi fazendo-se uso de um forno de micro-ondas doméstico. São relatadas na literatura algumas polimerizações ou copolimerizações, principalmente em cadeia, envolvendo diferentes tipos de monômeros (SADICOFF,AMORIM,MATTOS,2000).

Nos anos de 1980, este interesse renovou-se devido às propriedades intrínsecas existentes na aplicação de micro-ondas (TANRATTANAKUL, et al,2005).

\subsubsection{Interação Micro-ondas versus Materiais}

De maneira geral, existem três tipos de categorias as quais os materiais, quando submetidos à irradiação com micro-ondas, podem ser classificados quanto a sua interação (propriedade dielétrica):

- materiais transparentes (materiais com baixa perda dielétrica): a radiação atravessa o material com pouca ou nenhuma interferência do material sobre o campo de micro-ondas;

- materiais opacos (condutores elétricos) a radiação é refletida e não penetra no material; e

- materiais absorvedores (materiais com alta perda dielétrica): absorvem energia por meio da irradiação com micro-ondas até determinado nível, de acordo com o valor do coeficiente de perda dielétrica.

$\mathrm{Na}$ Figura 13, são mostrados os comportamentos dos três grupos de materiais: transparentes, opacos, e absorvedores de micro-ondas. 
Figura 13 - Comparação entre os diferentes tipos de materiais: transparente, opaco, absorvedores (naturais e com materiais absorvedores adicionados)

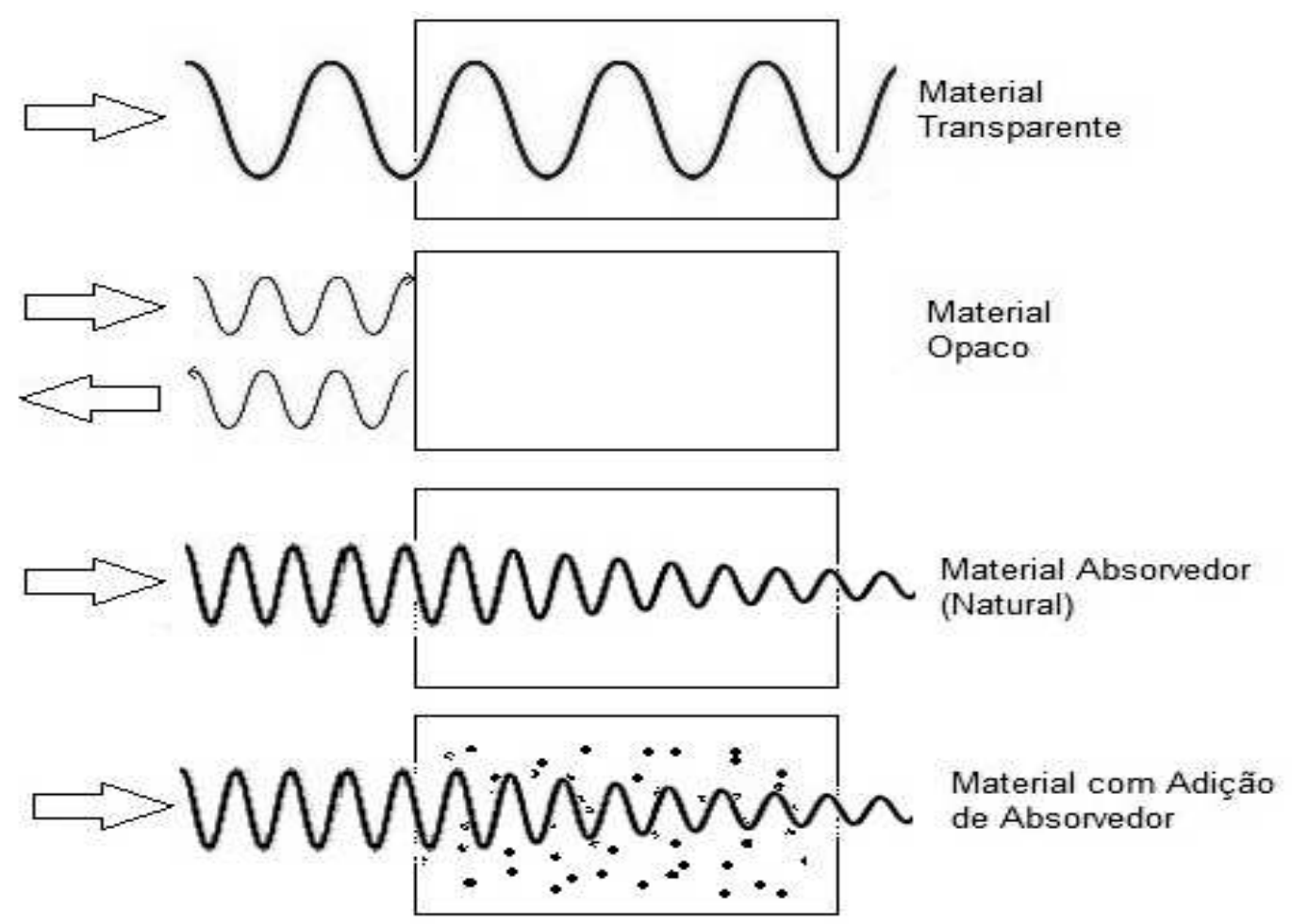

Fonte: Clark et al,2000.

Um quarto tipo de interação também pode ser observado quando é feita a adição de um material absorvedor em um material transparente a micro-ondas. É o tipo de interação observada em materiais compósitos ou materiais multifásicos, onde um dos materiais constituintes possui valores altos de perda dielétrica. A mistura de absorvedores é realizada de forma a aproveitar o aquecimento seletivo que a irradiação com micro-ondas proporciona (CLARK et al,2000).

Para o calor ser gerado com o material, as micro-ondas devem ter capacidade de entrar no material, serem absorvidas e transmitir energia, como foi apresentado anteriormente. A constante dielétrica e o fator de perda dielétrica são as propriedades físicas que quantificam a capacidade da conversão de energia no interior de um material absorvedor de micro-ondas. Especificamente a constante dielétrica é uma medida que indica a polaridade de uma material ou substância, e o fator de perda dielétrica indica a eficiência da conversão de energia eletromagnética em calor (BARBOZA,2001). 
Os processos de transferência de energia entre as moléculas, em materiais absorvedores de micro-ondas, podem ser de dois tipos: rotação de dipolo, e condução iônica. Para freqüências de radiação altas (como ultravioleta, por exemplo), os dipolos não conseguem acompanhar as mudanças do campo elétrico, e para freqüências muito baixas (como infravermelho, por exemplo) a reorientação molecular é muito mais rápida do que a alternância dos campos. Para ambos os casos, não irá ocorrer o aquecimento do material. Para freqüências compreendidas entre estes dois casos limites, os dipolos elétricos acompanham as mudanças do campo elétrico e parte da energia eletromagnética é armazenada, transformando-se em calor, devido ao atrito dos dipolos com as moléculas vizinhas (FORTUNY,2008).

$\mathrm{O}$ aquecimento a partir da rotação de dipolos relaciona-se com 0 alinhamento das moléculas (que têm dipolos permanentes ou induzidos) com o campo elétrico aplicado. Quando o campo é removido as moléculas voltam a um estado desordenado e a energia que foi absorvida para esta orientação nestes dipolos é dissipada na forma de calor (SANSEVERINO,2002).

No aquecimento de alimentos em um forno de micro-ondas doméstico o principio é esse, utilizando como fonte de absorção de micro-ondas, moléculas de água, pois os alimentos geralmente contêm certo teor de água. A água é formada por moléculas polares. A radiação de micro-ondas, na frequência de $2,45 \mathrm{GHz}$, padrão em fornos de micro-ondas domésticos, e reatores para síntese, oscila 2,45 x 109 vezes por segundo, carregando energia que pode ser absorvida pelas moléculas de água, ocorrendo um pronto aquecimento (SANSEVERINO,2002).

Por outro lado, também se deve considerar a fração de calor gerado via condução iônica, principalmente em materiais que se encontram em sua forma líquida. O calor é gerado por meio da fricção que acontece pela migração de íons dissolvidos quando sob a ação do campo eletromagnético. Esta geração depende do tamanho, carga, condutividade dos íons dissolvidos e interação destes últimos com o solvente. Ao contrário do mecanismo de rotação do dipolo, o aumento de temperatura durante o aquecimento do material também resulta no incremento da mobilidade dos íons e, consequentemente, na maior eficiência do aquecimento pelo mecanismo de condução iônica (FORTUNY,2008 e HAYES,2003).

Adicionalmente, o mecanismo de aquecimento via micro-ondas é independente da condutividade térmica do material irradiado. Dessa forma, o uso de micro-ondas oferece uma boa solução para operação com materiais que não possuem 
uma boa condutividade térmica, como é o caso dos polímeros, e esta forma relativamente nova de transferência de energia proporciona diversas vantagens distintas do aquecimento realizado em estufas e fornos convencionais:

- altamente seletivo;

- rápido (quase instantâneo); e

- controlável.

A energia transmitida via micro-ondas possui um comprimento de onda grande se comparado a outras radiações, e oferece um maior poder de penetração que outras radiações, como ultravioleta ou feixe de elétrons. Apesar desta vantagem, a frequência de micro-ondas não oferece energia o suficiente para proporcionar a quebra de ligações químicas, ocorrendo somente aquecimento dissipativo acelerado, e a consequente distribuição de energia através do volume do material (TANRATTANAKUL, et al,2005).

Como a energia é transferida pelo campo eletromagnético, quaisquer nãouniformidades neste campo eletromagnético irão resultar em aquecimento irregular. Além disso, na medida em que os diferentes tipos de materiais são processados, ocorrem alterações físicas e estruturais que afetam as suas propriedades dielétricas. $\mathrm{Na}$ Figura 14, é mostrado o comportamento para alguns tipos de materiais.

Figura 14 - Fator de perda dielétrica $X$ energia absorvida por volume para alguns tipos de materiais.

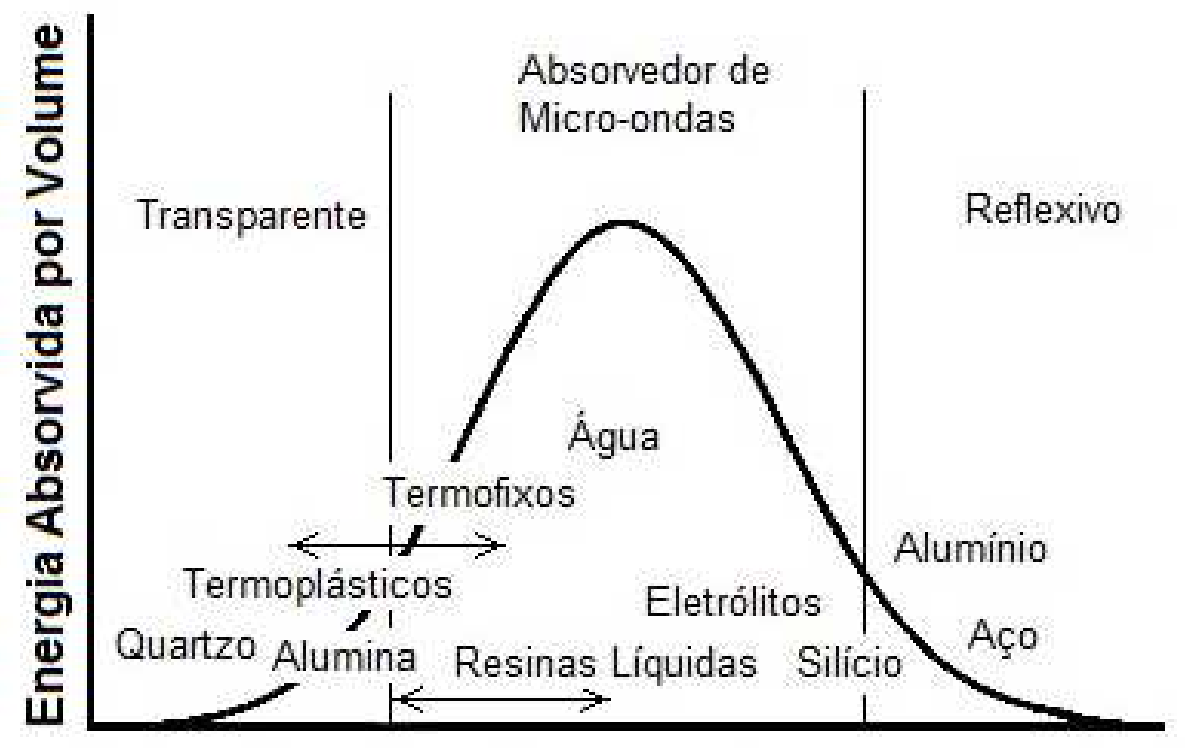

Fator de Perda Dielétrica ( $\varepsilon$ ")

Fonte: Tanrattanakul, et al,2005. 
Assim, a capacidade de micro-ondas para gerar calor também varia durante o processo. Transformações acentuadas na capacidade de absorção de microondas pelo material podem causar dificuldades com modelagem de processos e controle. Compreender a interação dos materiais com as micro-ondas é uma etapa importante dentro do processamento.

Na Figura 14, a diferença existente entre a capacidade de absorção de micro-ondas em resinas líquidas, por exemplo, é considerável se for realizada uma comparação com estas mesmas resinas após serem submetidas ao processo de cura via micro-ondas (vide termofixos na Figura 14). Definida esta etapa, faz-se necessária à definição do equipamento a ser utilizado no processamento (CLARK et al,2000).

\subsubsection{O Efeito Micro-ondas}

Desde o começo das primeiras pesquisas com o emprego de irradiação de micro-ondas para síntese química, foram notadas substanciais diferenças nos tipos de produtos obtidos, quantidade de produtos, e taxa de reação dos reagentes. Estas diferenças levaram a especulações sobre a ocorrência de efeitos "específicos" e "nãotérmicos" do aquecimento por micro-ondas.

Como exemplo desses efeitos, além de reações mais rápidas e com maiores rendimentos, existem ainda reações que normalmente não ocorrem com o aquecimento convencional, mas que com a irradiação com micro-ondas passam a ocorrer. Também são verificadas mudanças na seletividade em reações quando as micro-ondas são empregadas (SANSEVERINO,2002). Reações de Wittig (WittigEmmons-Horner), em síntese orgânica, já foram conduzidas em forno de micro-ondas doméstico em vaso aberto, na ausência de solventes. Um fato marcante observado neste caso, é que a reação de um derivado de esteróide não ocorreu usando o procedimento tradicional (reação em solução sob refluxo e aquecimento convencional). Outra reação, em que não são obtidos produtos por aquecimento convencional, é a saponificação do 2,4,6-trimetil-benzoato de octila. Porém, com emprego de microondas, a reação se desenvolveu com a formação do respectivo ácido com bons rendimentos (SANSEVERINO,2002). 
Atualmente, tem-se conhecimento de que na maior parte das vezes as reações assistidas por micro-ondas são influenciadas essencialmente por efeitos térmicos e cinéticos. Em outras palavras, as reações obtidas via irradiação de microondas são consequência de altas temperaturas atingidas muito rapidamente. Ainda existem controvérsias sobre a existência de "efeito específico", que está relacionado a reações com resultados diferentes dos obtidos pelas vias convencionais, e os efeitos "não-térmicos", ocasionados pela interação direta do campo elétrico e sua influência sobre as transformações químicas.

O grande problema do estudo destes três efeitos (térmico, específico e não-térmico) é que dois ou três deles podem ocorrer ao mesmo tempo, sendo responsáveis pelo fenômeno observado, tornando uma avaliação clara e objetiva bastante complexa (KAPPE,DALLINGER,MUPHREE,2009).

\subsection{CONCEITOS BÁSICOS SOBRE FILTRAÇÃO E ADSORÇÃO}

\subsubsection{Filtração}

Filtração, de forma resumida, é a operação unitária que trata da separação de um sólido do fluido que the transporta, seja este fluido líquido ou gasoso. Em todos os casos, a separação ocorre quando o sólido se acumula entre os poros do filtro que atua como elemento filtrante no processo, formando uma camada sobre este filtro. Para esta camada de sólido formada sobre o filtro tem-se o nome de filtrado, ou torta (FOUST,1982 , MCABE,2007 e ASHBY,2013).

De modo geral, a filtração atua de forma bastante similar seja a nível laboratorial quanto a nível industrial, diferindo principalmente quanto aos volumes de material envolvidos na execução da separação. Na Figura 15, é mostrado o esquema de um sistema de filtração usado em laboratório, com os seus diferentes componentes. 
Figura 15 - Componentes de um sistema de filtração típico, usado em laboratório

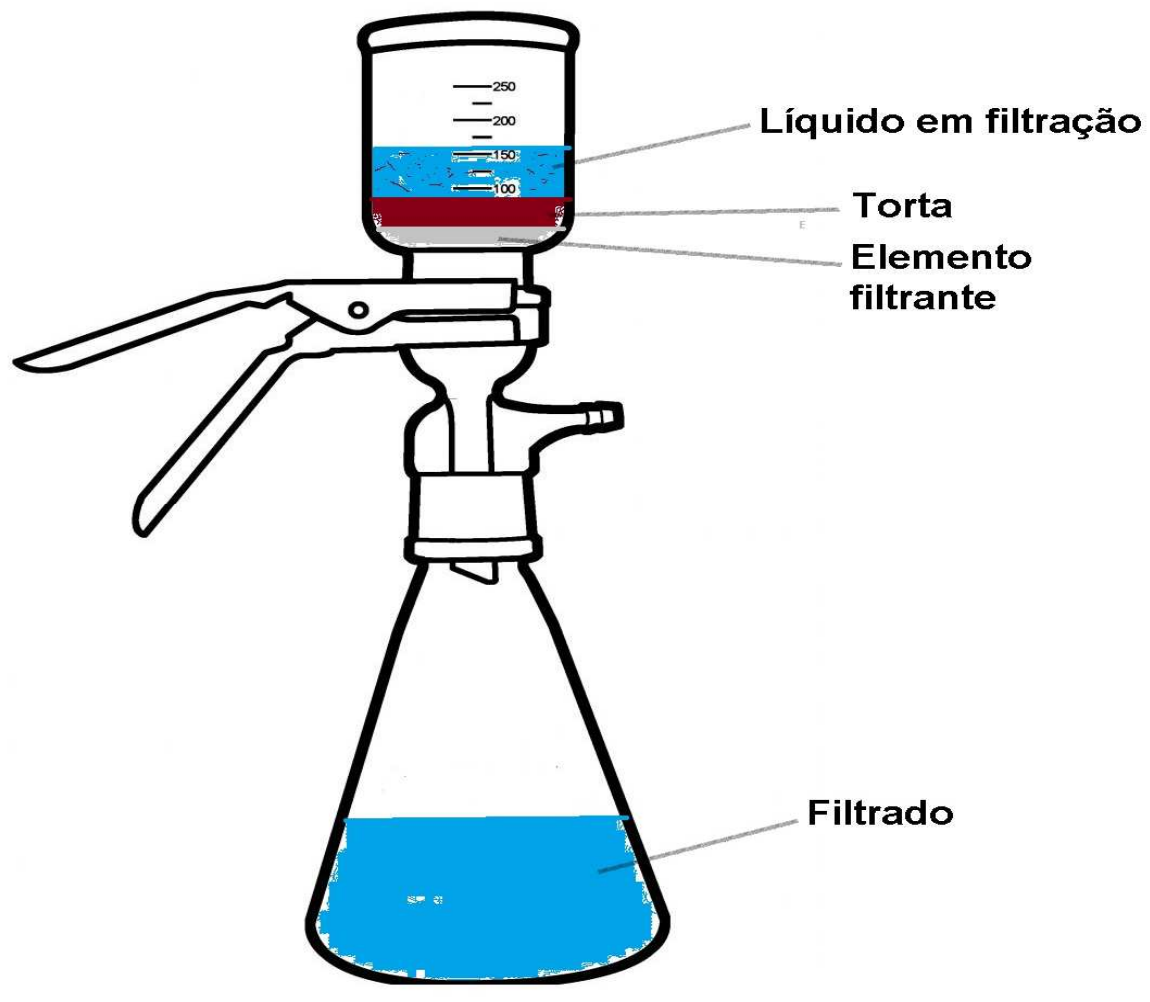

Fonte: Foust, 1982.

\subsubsection{Tipos de Filtros}

O líquido flui através do meio filtrante sob uma diferença de pressão através do meio. Por conseguinte, os filtros são classificados de acordo com este aspecto:

- Filtros que operam acima da pressão atmosférica no fluxo superior do elemento filtrante;

- Filtros que operam com a pressão atmosférica no fluxo superior do elemento filtrante e baixa pressão ou vácuo na corrente inferior.

Pressões superiores a atmosférica são geradas pela ação da força da gravidade que age sobre a coluna de líquido, por uma bomba ou ventilador, ou pela força centrífuga (em centrífugas). Em um filtro no qual usa-se apenas a gravidade, o elemento filtrante não pode ser mais fino do que um leito de partículas grosseiras, tais como areia. Por conseguinte, em aplicações industriais os filtros deste tipo são restritos a separação por gravidade de fluidos espessos, a clarificação de água potável e tratamento de águas residuais (FOUST,1982 , MCABE,2007 e ASHBY,2013).

A maioria dos filtros industriais são filtros de pressão, vácuo ou separadores centrífugos. Eles também podem ser de operação contínua ou descontínua, 
dependendo da concentração dos sólidos filtrados, sendo a filtração conduzida de forma contínua ou intermitentemente. Para tanto, a operação do ciclo de filtração intermitente o processo é interrompido periodicamente para permitir a descarga de sólidos acumulados. Por outro lado, nos filtros com operação contínua, a descarga dos filtros é realizada de maneira ininterrupta, enquanto a máquina está em operação.

Quanto aos mecanismos de filtração, pode-se ter filtros de torta, clarificador, e de fluxo transversal. Na Figura 16, são mostrados os mecanismos, como é a sua alimentação, e por quais meios o filtrado pode ser obtido.

Figura 16 - Mecanismos de filtração: a) filtro de torta (fluxo perpenticular), b) filtro clarificador (fluxo perpenticular), e c) filtro de fluxo transversal

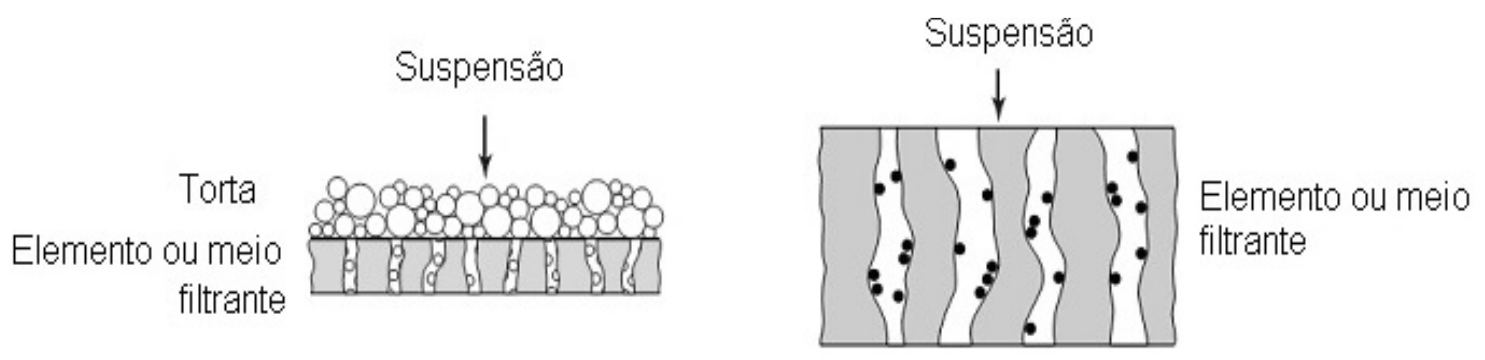

a) b)

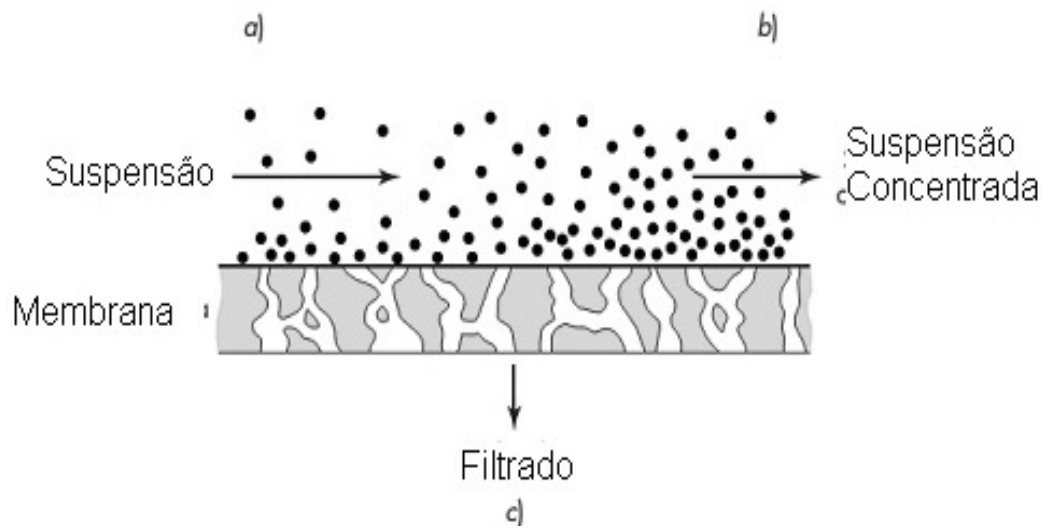

Fonte: Ashby,2013.

Filtros de torta são usados na separação de grandes quantidades de sólidos na forma de uma torta ou de uma suspensão de cristais Muitas vezes eles incluem dispositivos para a lavagem da torta e para remover a maior quantidade possível de líquido nos sólidos antes da descarga.

Filtros clarificadores removem pequenas quantidades de sólidos para produzir um gás limpo ou líquidos transparentes, tais como bebidas. As partículas sólidas são presas dentro do elemento filtrante, ou nas superfícies exteriores. Peneiras de filtros clarificadores possuem poros no elemento filtrante que são muito maiores em diâmetro do que as partículas a serem removidas. 
Por fim, filtros de fluxo cruzado são usados em fluidos sob baixas pressões, e em altas velocidades, ao longo do elemento filtrante. Uma camada fina de sólidos é formada na superfície do elemento filtrante, mas a alta velocidade do líquido mantém a camada formada (FOUST,1982, MCABE,2007 e ASHBY,2013).

\subsubsection{Elementos Filtrantes}

Os elementos filtrantes de qualquer filtro devem atender aos seguintes requisitos:

1. manter os sólidos filtrados, produzindo um filtrado razoavelmente claro;

2. ser quimicamente resistentes e ter resistência mecânica de química suficiente para suportar as condições do processo;

3. deixar a torta formada com aparência limpa e completa; e

4. economicamente viável.

Os elementos filtrantes mais comuns em aplicações industriais são tecidos, com variações quanto a massa e modelo do tecido, de acordo com a necessidade de uso. Líquidos corrosivos requerem o uso de outros meios de filtragem, tais como lã, monel ou aço inoxidável, vidro ou papel. fibras sintéticas como o nylon, polipropileno, e vários poliésteres também têm elevada resistência química.

\subsubsection{Adsorção}

O processo de adsorção decorre de ações interfaciais que permitem que as moléculas do adsorvido sejam transferidas para a superfície do adsorvente e fiquem ali retidas. A adsorção pode ser:

1. Química: quando há reação entre o sítio ativo de adsorção do adsorvente e o adsorvido e

2. Física: quando envolve forças de van der Waals e interações eletrostáticas entre $o$ adsorvente e $o$ adsorvato (FOUST,1982).

\subsubsection{Adsorventes}

O adsorvente é o material cuja superfície ocorre a adsorção das moléculas do fluido a ser tratado. A maioria dos adsorventes são materiais muito porosos e a 
adsorção ocorre principalmente nas paredes dos poros ou em locais específicos dentro da partícula. Uma vez que os poros são geralmente muito pequenos, a área de superfície interna é de várias ordens de grandeza maior do que a área externa e atingem frequentemente valores entre $500-1000 \mathrm{~m}^{2} / \mathrm{g}$.

A separação ocorre em virtude das diferenças de massa molecular e polaridade molecular, o que pode levar a algumas moléculas aderir mais fortemente que outras, ou porque os poros são demasiado pequenos para apoiar moléculas maiores. Em muitos casos, o componente adsorvido é fixado tão fortemente que permite uma separação completa do componente a partir de um fluido, com pouca adsorção de outros componentes (FOUST,1982, MCABE,2007 e ASHBY,2013).

Os adsorventes podem apresentar diferentes formas e tamanhos, em forma de pequenas esferas ou cilindros, escamas ou grânulos, com densidade entre 400 $\mathrm{kg} / \mathrm{m}^{3}$ e $900 \mathrm{~kg} / \mathrm{m}^{3}$ e com tamanho entre $2 \mathrm{~mm}$ e $6 \mathrm{~mm}$. Existem diferentes configurações de equipamentos e as mais usuais são as colunas de recheio ou empacotadas (packed beds), ou ainda chamadas de leito fixo, semelhantes às colunas de absorção. Os processos de adsorção operam, geralmente, por meio de um sistema cíclico no qual o adsorvente é submetido a uma etapa de adsorção, durante a qual as substâncias de interesse são adsorvidas, seguida de uma etapa de regeneração ou dessorção, na qual os componentes adsorvidos são removidos e o adsorvente é regenerado, ficando apto para uma nova etapa de adsorção.

É possível regenerar o adsorvente, a fim de obter o adsorvato em concentrado. A recuperação ocorre principalmente em aplicações em que vapores orgânicos são adsorvidos, como em processos envolvendo tintas, tintas de impressão e soluções de formação de películas ou revestimentos por tinta. $\mathrm{O}$ ar carregado de solvente é enviado primeiro para um condensador arrefecido a água, a fim de recolher uma parte do solvente, embora em geral não é adequado o arrefecimento do gás a temperaturas inferiores à temperatura ambiente, numa tentativa de eliminar a perda de solvente. $\mathrm{O}$ ar, com um pequeno quantidade de solvente, é passado através de um leito de partículas de adsorventes de carbono, que pode reduzir a concentração de solvente para concentrações inferiores a 1 ppm.

Também se utiliza adsorção em carvão para remover contaminantes, tais como $\mathrm{H}_{2} \mathrm{~S}, \mathrm{CS}_{2}$ e outros compostos com odor, no ar que circula em sistemas de ventilação. Na grande maioria dos carros novos são colocados cartuchos de carbono para impedir a passagem de vapores de gasolina para a atmosfera. 


\subsubsection{Principais Adsorventes}

Os primeiros adsorventes microporosos utilizados foram a sílica gel (diâmetro de poro em torno de $20 \AA$ ), a alumina ativada (diâmetro de poro entre 20 e $50 \AA$ ) e o carvão ativado (diâmetro de poro entre 15 e $25 \AA$ ) e, mais recentemente, as zeolitas (aluminossilicatos cristalinos porosos - diâmetro de poro entre 4 e $13 \AA$ ). A estrutura porosa do adsorvente é composta de diferentes tamanhos de poros, conforme mostrado na Figura 17.

Figura 17 - Detalhe da estrutura de poros de um adsorvente

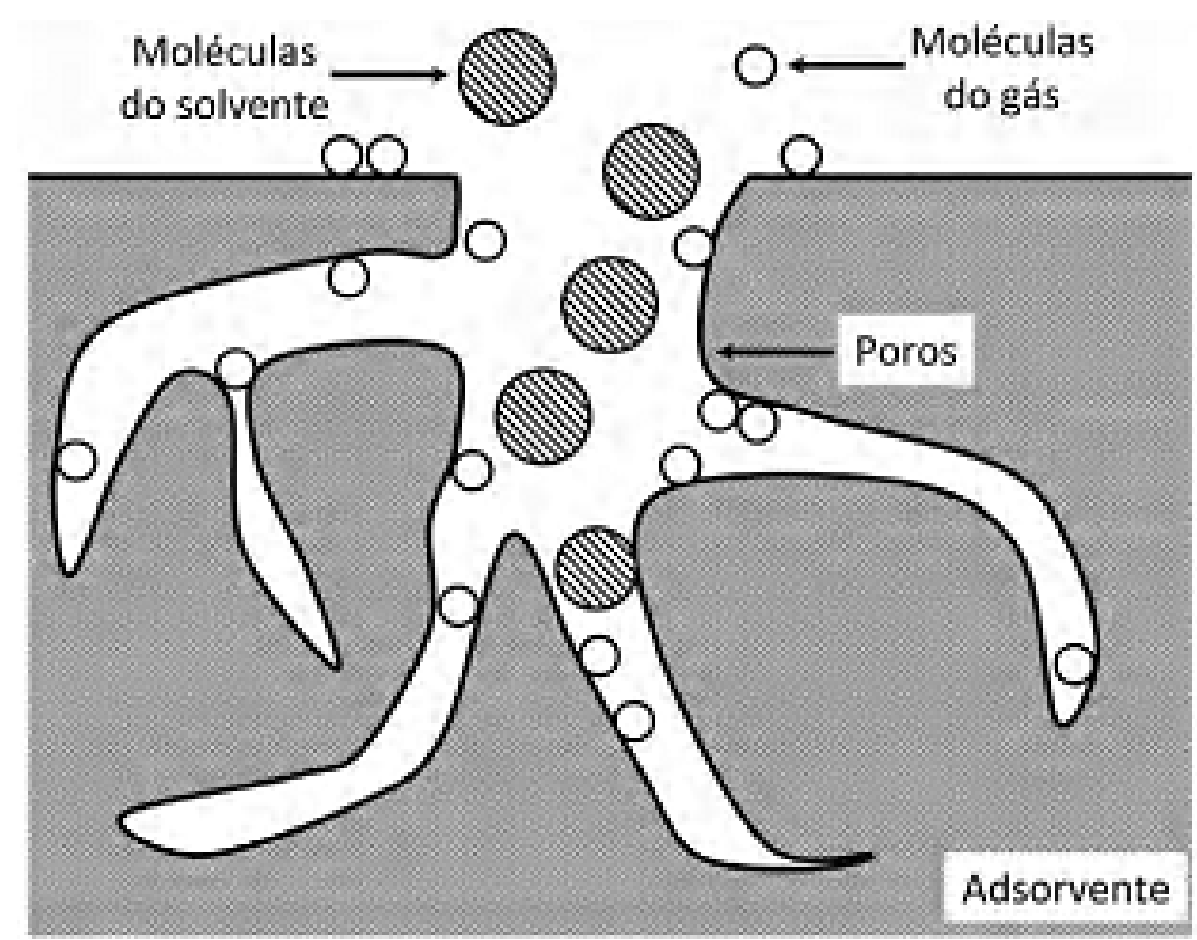

Fonte: Rouquerol,1999).

Chama-se de macroporosidade a porção da porosidade com tamanhos de poros maiores que $50 \mathrm{~nm}$ ou $500 \AA$; e abaixo desse valor tem-se a microporosidade.

\subsubsection{Carvão Ativado}

O carvão ativado é o adsorvente mais utilizado no tratamento de águas de abastecimento. Ele pode adsorver uma grande variedade de compostos que geram odor e gosto à água de consumo, tais como agrotóxicos e cianotoxinas. A eficiência 
do carvão ativado é atribuída ao tamanho e à estrutura dos poros, à superfície específica, à reatividade dos diferentes componentes do material, às características do adsorvato (massa molecular e grupos funcionais da molécula) e às características da água (turbidez, metais dissolvidos, pH, temperatura, carbono orgânico dissolvido). Ensaios em laboratório são indispensáveis para determinar seu desempenho.

O carvão ativado pode ser extraído a partir de casca do coco, ossos, carvão betuminoso e madeira. Após definida a granulometria desejada, a produção envolve, basicamente:

i) carbonização ou pirólise: que remove material volátil da matéria-prima e cria a estrutura porosa inicial; e

ii) ativação ou oxidação: que desenvolve os vazios internos ao aplicar gases oxidantes a elevadas temperaturas.

As características do carvão ativado dependem da origem da matéria-prima e do tipo de ativação. Para determinar a dosagem necessária de carvão ativado para alcançar uma concentração mínima desejada de uma substância na água tratada, é necessário o estudo das isotermas de adsorção que representam a relação entre a quantidade de adsorvato por unidade de adsorvente e a concentração de equilíbrio do adsorvato na solução sob temperatura constante. As isotermas mais utilizadas para descrever o equilíbrio da adsorção são os modelos de Freundliche de Langmuir.

A presença de matéria orgânica, cloro, ferro, manganês e coagulante reduz a capacidade de adsorção das substâncias de interesse na água a ser tratada devido à competição pelos sítios de adsorção. A capacidade de adsorção para alguns poluentes normalmente aumenta com a redução do $\mathrm{pH}$ e da temperatura (FOUST,1982).

\subsection{Zeólitas}

As zeólitas são aluminossilicatos, naturais ou sintéticos, com uma estrutura de poros muito finos, regulares, especialmente eficazes para aplicações de adsorção em gases. Por exemplo, a mordenita tem uma superfície interna de $400 \mathrm{~m}^{2} / \mathrm{g}$, e a da clinoptilolita é de $300 \mathrm{~m}^{2} / \mathrm{g}$. Para o caso da mordenita, a quantidade de $\mathrm{SO}_{2}$ adsorvido é de $47-120 \mathrm{ml} / \mathrm{g}$.

Historicamente, com a descoberta da stilbita, as zeólitas foram reconhecidas pela primeira vez em 1756 pelo mineralogista sueco Baron Axel 
Frederick Consted. O termo zeólita (zéo e líthos) vem do grego e significa pedra que ferve. Em 1845, Way descobriu que determinados tipos de solos tinham a propriedade de reter sais de amônia, e Breck constatou que os silicatos hidratados de alumínio no solo eram os responsáveis pela troca iônica.

As zeólitas englobam um grande número de minerais naturais e sintéticos que apresentam características comuns. São aluminosilicatos hidratados de metais alcalinos ou alcalinos terrosos (principalmente sódio, potássio, magnésio e cálcio), estruturados em redes cristalinas tri-dimensionais, compostas de tetraedros do tipo $\mathrm{TO}_{4}$ ( $\mathrm{T}=\mathrm{Si}, \mathrm{Al}, \mathrm{B}, \mathrm{Ge}, \mathrm{Fe}, \mathrm{P}, \mathrm{Co}$ ) unidos nos vértices por meio de átomo de oxigênio. Nas zeólitas mais comuns, na fórmula TO4, o T representa o Si ou o Al (LUZ,1995).

Alguns usos de zeólitas, a nível industrial:

a) Dessecação/aquecimento solar/refrigeração: controle de umidade a níveis onde outros dessecantes, tais como os géis de silica e alumina, são menos eficientes. A clinoptilolita e chabazita são usadas como armazenadores e fornecedores de calor proveniente da energia solar. A desidratação durante 0 dia e sua hidratação durante a noite podem resultar numa troca de calor suficiente para resfriar ou aquecer ambientes;

b) Purificação e separação industrial de gases: a chabazita tem sido usada para purificar gás metano por meio da remoção de contaminantes, tais como água, $\mathrm{SO}_{2}, \mathrm{CO}_{2}$. Desde 1968 que os Estados Unidos vêm utilizando industrialmente a mordenita na adsorção de $\mathrm{CO}_{2}$ de gás natural; e

c) Controle de odor: as zeólitas têm sido utilizadas para controlar o odor resultante da exalação de amônia e gás sulfídrico, em áreas onde se pratica a criação de animais confinados (LUZ,1995).

\subsubsection{Alumina Ativada}

A alumina é encontrada na natureza basicamente compondo parte do minério bauxita, e a principal base para a produção de alumínio, seguido o processo Bayer. O nome "alumina ativada" é aplicado a uma classe de adsorventes preparada por tratamentos térmicos a partir de uma forma de alumina hidratada, como hidróxidos cristalinos, oxi-hidróxidos, ou alumina em gel. É um adsorvente conhecido de longa data, com aplicação desde os anos de 1930.

Para a obtenção de alumina ativada com boas propriedades adsorventes é 
necessário controlar: a natureza química e física da matéria-prima usada (estrutura, tamanho de partícula, tamanho de cristal, pureza, etc); as condições de tratamento térmico (tipo de forno, atmosfera, perfil tempo-temperatura de aquecimento, entre outros e métodos usados para interpretar e medir os dados de adsorção (ROUQUEROL, 1999).

\subsection{CONCEITOS BÁSICOS SOBRE POTABILIDADE DE ÁGUA PARA CONSUMO HUMANO}

\subsubsection{Introdução}

Todo o presente trabalho buscou focar no desenvolvimento de um filtro adequado para produzir água para o consumo humano. Neste sentido, além do embasamento teórico sobre o material que está sendo avaliado, para ser empregado como elemento filtrante, faz-se necessário a apresentação dos parâmetros que deverão ser seguidos como referência para esta pesquisa.

Desta forma, dentro dos conceitos sobre potabilidade de água, serão apresentados os seguintes aspectos para uma melhor referência: histórico da legislação, aspectos legais em vigência no Brasil, e por fim, os parâmetros de potabilidade a serem seguidos.

\subsubsection{Histórico da Legislação Brasileira}

A primeira norma sobre padrões de potabilidade do Brasil, publicada pelo Estado de São Paulo por meio do Decreto Estadual ㄲo 15.642 de 9 de fevereiro de 1946, estabeleceu parâmetros mínimos de qualidade para águas potáveis e gelo. Também em São Paulo, em 4 de julho de 1958, o Decreto Estadual $n^{\circ} 33.047$, estabeleceu novos parâmetros físico-químicos e bacteriológicos e padronizou as condições de potabilidade das águas destinadas à alimentação. Este decreto serviu de base para a legislação federal sobre o tema na década de 1970. A primeira legislação federal sobre padrões de potabilidade foi criada pelo Decreto Federal oㅜ 79.367 de 9 de março de 1977. Este decreto estabeleceu que a competência sobre a definição dos padrões de potabilidade da água para consumo humano seria do Ministério da Saúde e que estes deveriam ser observados em todo território nacional. 
Em 14 de março de 1977 foi publicada a Portaria nำ 56 BSB que normalizou o Decreto Federal n 79.367 para todo o território. Após treze anos, foi publicada a Portaria $\mathrm{n}$ 36 GM, de 19 de janeiro de 1990, que revogou a Portaria no 56 BSB. Em 29 de dezembro de 2000, foi publicada a Portaria no 1469, estabelecendo o controle e a vigilância da qualidade da água para o consumo humano. Esta portaria foi modificada pela Portaria nํ5, 518, de 25 de março de 2004. A referida portaria apenas adequou as questões relativas às atribuições da Coordenação Geral de Vigilância em Saúde Ambiental (CGVAM) e Fundação Nacional de Saúde (FUNASA), não alterando os padrões de potabilidade anteriormente propostos. Em 12 de dezembro de 2011, uma nova versão da portaria sobre potabilidade foi publicada. Foi na Portaria n- 2.914/2011 que foram apresentados parâmetros mais completos, tanto do ponto de vista microbiológico quanto químico. Entre os novos parâmetros, químicos pode-se citar a inclusão de alguns agrotóxicos e metais (GUIA,2012).

Após a emissão da Portaria n 2.914/2011 novas discussões seguiram ocorrendo dentro do âmbito do Ministério da Saúde. Em 28 de setembro de 2017, o Ministério da Saúde promulgou a Portaria de Consolidação n 5/2017, onde revoga a Portaria no 2.914, e reúne seu conteúdo juntamente com o de outras portarias, consolidando as normas relativas as ações e serviços prestados pelo Sistema Único de Saúde (SUS). O conteúdo da Portaria nº 2.914 foi reunido no Anexo XX, em que ficam definidos os procedimentos de controle e de vigilância da qualidade da água para consumo humano e seu padrão de potabilidade (ILSI,2019).

Mais recentemente, em 9 de maio de 2018, o Conselho Nacional de Saúde, publicou o consolidado das propostas e moções aprovadas na $1^{\text {a }}$ Conferência Nacional de Vigilância em Saúde. No que tange aos parâmetros de potabilidade foi promulgado, dentro do Sub-eixo ํㅡ 2 "Responsabilidades do Estado e dos governos com a vigilância em saúde", o Item 2.62, ao qual segue transcrito integralmente: "Rever os parâmetros de potabilidade da água, regulamentados pela Portaria MS no 2914/2011, que dispõe sobre os procedimentos de controle e de vigilância da qualidade da água para consumo humano e seu padrão de potabilidade, considerando aspectos territoriais, afim de pesquisar teor de flúor, agrotóxicos, metais pesados e reavaliação dos valores máximos permitidos". Dessa forma, conforme pode-se observar no registrado pela Resolução n 583/2018, estudos seguirão sendo feitos de forma a melhor consolidar os parâmetros já existentes (BRASIL,2018). 


\subsubsection{Aspectos Legais Importantes sobre Potabilidade}

Dada a importância que o assunto impõe, cabe a apresentação dos principais pontos que devem ser observados dentro da legislação em vigência. A portaria em vigor, a Portaria $\mathrm{n}^{\circ}$ 5/2017, permite que sejam destacados dois pontos que devem ser de atenção dos diferentes usuários envolvidos, sejam empresas, governo, ou simples pessoas físicas em seus domicílios.

O primeiro ponto trata de que tipos de utilização de água se enquadram como "consumo humano". Neste sentido, o art. 5ำ da Portaria ํํ 5/2017 é claro em indicar e conceituar sobre a água para consumo humano: "água potável destinada à ingestão, preparação e produção de alimentos e à higiene pessoal, independentemente da sua origem". A definição é abrangente, mas oculta alguns detalhes que devem ser evidenciados.

Está englobado em "água para consumo humano" as águas utilizadas em pias e chuveiros dos banheiros, por seu uso na higiene pessoal. Esse é um ponto que tem passado despercebido por muitos profissionais quando da reutilização de água. Com a crescente escassez de reservatórios de água, a preocupação com a reutilização de águas (que não atendam aos parâmetros de potabilidade) na descarga de vasos sanitários (os quais demandam um tratamento menos rigoroso) tem sido mais comum. Entretanto, caso não se tome os devidos cuidados, a mesma água pode acabar sendo direcionada para pias e chuveiros, resultando na ingestão de água imprópria para consumo humano, além de gerar contaminação alimentar e outros problemas de saúde para os trabalhadores. Por esse motivo, é necessário se saber compatibilizar as práticas sustentáveis de reutilização da água, com os devidos controles para se evitar que as águas que não atendam aos padrões de potabilidade, mesmo que tratadas, não gerem riscos à saúde dos trabalhadores. Assim, recomenda-se o reuso em descargas sanitárias, o reaproveitamento de águas industriais em jardinagem e lavagem de piso para racionalizar o uso da água, sem gerar maiores riscos de contaminação dos consumidores (VERDE GHAIA,2019 e IUS NATURA,2019).

O segundo ponto que a legislação apresenta é quanto a necessidade de autorização de órgãos específicos para fornecimento de água para trabalhadores, quando no caso de empresas, por exemplo. Podem ocorrer variações de acordo com o estado em que a empresa está localizada, e com a maneira que a mesma recebe e 
fornece a água potável. Caso seja abastecida por concessionarias de serviço público, não é necessário solicitar autorização a nenhum órgão para fornecê-la aos trabalhadores.

Por outro lado, caso a empresa necessite realizar a própria captação e tratamento para fornecimento aos trabalhadores (classificada como solução alternativa coletiva de abastecimento de água) pode ser necessária uma autorização da vigilância sanitária municipal para fornecimento. De uma forma geral, o art. 14 da Portaria n 05/2017 determina: "O responsável pela solução alternativa coletiva de abastecimento de água deve requerer, junto à autoridade municipal de saúde pública, autorização para o fornecimento de água tratada, mediante a apresentação dos seguintes documentos: I - nomeação do responsável técnico habilitado pela operação da solução alternativa coletiva; II - outorga de uso, emitida por órgão competente, quando aplicável; e III - laudo de análise dos parâmetros de qualidade da água previstos nesta Portaria". Apesar da obrigatoriedade da disposição legal supramencionada, na prática, boa parte das vigilâncias sanitárias municipais não aplica a legislação conforme anteriormente exposta, deixando de prover a autorização, mesmo que o interessado a solicite.

Para sanar este tipo de situação, recomenda-se apresentar à vigilância municipal solicitação para fornecimento de água, junto com o plano de amostragem de controle da qualidade da água, o responsável técnico pelo monitoramento da potabilidade, e a outorga do órgão ambiental local/estadual. Ainda que a vigilância municipal deixe de se manifestar sobre a autorização do fornecimento, o protocolo de apresentação será documento suficiente para demonstrar a adequação do fornecimento de água potável. Ressalta-se que apesar da dificuldade junto a vigilância municipal, a empresa solicitante deve manter os parâmetros de potabilidade conforme indica a legislação. Somente assim, mesmo sem o registro, a empresa que capta a água que seus trabalhadores consomem poderá ter algum tipo de respaldo legal.

No estado de São Paulo, a situação é diferenciada, com existência de legislação própria. A Resolução SS no 65/2005 estabeleceu a necessidade de submissão à Autoridade Sanitária Municipal a solicitação para fornecimento de água. Tal solicitação é realizada por meio do cadastro no SISAGUA - Sistema de Informação de Vigilância da Qualidade da Água para Consumo Humano. Assim, ao realizar o cadastro devido e a mantê-lo atualizado anualmente, as empresas podem fornecer a água captada e tratada a seus funcionários. Mediante o compromisso legal de atender 
aos padrões de qualidade, cujos resultados das análises devem ser apresentados semestralmente (VERDE GHAIA,2019 e IUS NATURA,2019).

\subsubsection{Parâmetros de Potabilidade}

A norma legal em vigência, a Portaria ํㅡ 5/2017 estabelece em seu Anexo $\mathrm{XX}$ todos os requisitos necessários para fornecimento de água potável, e água para consumo humano. Em face a sua abrangência, são estabelecidos parâmetros conforme se segue, em cada um dos anexos contidos no Anexo XX da Portaria. Para fins de solução alternativa de fornecimento, a norma indica considerar os seguintes anexos:

- Anexo 1 - Tabela de Padrão Microbiológico da Água para Consumo Humano;

- Anexo 2 - Tabela de Padrão de Turbidez Para Água Pós-Filtração ou PréDesinfecção;

- Anexo 3 - Tabela de Metas Progressivas para Atendimento ao Valor Máximo Permitido de 0,5 UT para Filtração Rápida e de 1,0 UT para Filtração Lenta;

- Anexo 4 - Tempo de Contato Mínimo (Minutos) a ser observado para a desinfecção por meio da cloração, de acordo com concentração de cloro residual livre, com a temperatura e o pH da Água;

- Anexo 5 - Tabela de tempo de contato mínimo (minutos) a ser observado para a desinfecção por meio de cloraminação, de acordo com concentração de cloro residual combinado (cloraminas) e com a temperatura da água, para valores de $\mathrm{pH}$ da água entre 6 e 9;

- Anexo 6-Tabela de tempo de contato mínimo (minutos) a ser observado para a desinfecção com dióxido de cloro, de acordo com concentração de dióxido de cloro e com a temperatura da água, para valores de $\mathrm{pH}$ da água entre $6 \mathrm{e}$ 9;

- Anexo 7 - Tabela de padrão de potabilidade para substâncias químicas que representam risco à saúde;

- Anexo 8 - Tabela de Padrão de Cianotoxinas da Água para Consumo Humano;

- Anexo 9 - Tabela de Padrão de Radioatividade da Água para Consumo Humano;

- Anexo 10 - Tabela de Padrão Organoléptico de Potabilidade; 
- Anexo 11 - Tabela de Frequência de Monitoramento de Cianobactérias no Manancial de Abastecimento de Água;

- Anexo 14 - Tabela de número mínimo de amostras e frequência mínima de amostragem para o controle da qualidade da água de solução alternativa coletiva, para fins de análises físicas, químicas e microbiológicas, em função do tipo de manancial e do ponto de amostragem.

Para fins deste trabalho, em virtude do objetivo proposto de prover um filtro para uso doméstico e geral, serão considerados apenas os Anexos 2, 7 e 10 para uma melhor delimitação do escopo a ser estudado. Os Anexos 2, 7 e 10 serão apresentados ao final desta tese, nos ANEXOS 1, 2 e 3, respectivamente (BRASIL,2017). 


\section{MATERIAIS E MÉTODOS}

\subsection{MATERIAIS}

\subsubsection{Resíduo de Fibra de Vidro com Resina Epóxi - WOBBEN}

O resíduo constitui-se de uma mistura seca de fibra de vidro e resina epóxi curado, com tamanho de partículas inferior a $1 \mathrm{~mm}$, resultado da fabricação de pás eólicas empregada pela empresa WOBBEN Winpower Indústria e Comércio LTDA. O material foi usado como recebido, sendo prestadas apenas estas informações quando da doação do resíduo. O material compósito é classificado como Resíduo Industrial, por sua origem, e Resíduo Classe II - A, Não Perigoso, e Não Inerte, por suas características químicas de reatividade e potencial de contaminação (ABNT,2004). Por suas características deve ser mantido sob controle, isolado do meio-ambiente, dentro de tambores, em um centro de gerenciamento de resíduos industriais, sendo um custo permanente fixo para o seu gerador.

\subsubsection{Carvão Ativado}

O carvão ativado vegetal utilizado neste trabalho foi fornecido pela Shop Medclean, representante comercial da Synth, em embalagem de $500 \mathrm{~g}$, em grau P.A. O material foi usado como recebido, sem quaisquer alterações após o seu recebimento.

\subsubsection{Zeólita}

A zeólita granulada utilizada neste estudo foi fornecida pela Aquarismototal, revendedor da marca Prodac, em embalagens de $700 \mathrm{~g}$, em grau comercial. O material foi usado como recebido, sem quaisquer alterações após o seu recebimento. 


\subsubsection{Alumina Ativada}

A alumina ativada utilizada neste estudo foi fornecido pela Ideu Tecnologia Ambiental, em embalagens de $500 \mathrm{~g}$, em grau comercial. O material foi usado como recebido, sem quaisquer alterações após o seu recebimento.

\subsection{5. Água para Avaliação Final dos Elementos Filtrantes}

As amostras de água para avaliação final dos elementos filtrantes foram coletadas no rio Ipanema, município de Iperó/SP. O local foi escolhido em virtude de possibilitar a coleta de amostras de água doce de cursos d'água classe 2 (vide ANEXO 4), que também foram objeto de captação por empresas privadas, e entidades governamentais locais. O local tornou-se interessante no sentido de que quaisquer captações realizadas por estes grupos somente podem resultar em posterior devolução de água ao curso d'água original em condições similares ou melhores, as quais foram captadas. Isso faz com que o local seja de uso de vários grupos, e ao mesmo tempo controlado por estes mesmos grupos, no sentido de buscar a preservação do curso d'água para uso a longo prazo(SÃO PAULO,2019).

\subsection{MÉTODOS}

$\mathrm{Na}$ apresentação dos métodos e materiais utilizados no presente estudo, cabe contextualizar as condições as quais o mesmo teve de ser realizado. As pesquisas foram iniciadas em novembro de 2014, em uma condição em que a economia do país começava a inspirar cuidados, e que veio a se tornar bastante mais sensível nos anos que seguiram, sobretudo 2015 e 2016 (TRADING ECONOMICS,2019).

O trabalho teve que se encaixar dentro deste contexto econômico, tendo que lidar com a contração da economia nacional em curso na época, e com o pouco interesse em se investir em uma área que em períodos mais favoráveis economicamente já é difícil. Assim sendo, reforçaram-se as buscas por alternativas que enfatizassem a baixa aplicação de recursos, e a minimização de custos fixos existentes, o que novamente reforçou a área de enfoque escolhida para este trabalho. 


\subsubsection{Técnicas e Equipamentos}

As técnicas e equipamentos para verificação das propriedades físicas e químicas neste estudo serão os seguintes:

- Espectroscopia Vibracional de Absorção no Infravermelho por Transformada de Fourier (FTIR): Os espectros de FTIR foram obtidos num espectrômetro marca JASCO, modelo IR-100, equipado com suporte para análise de amostras líquidas;

- Análise Termogravimétrica (TGA): O equipamento usado foi o TGA/DTA modelo 851, marca Mettler-Toledo. As amostras foram analisadas com velocidade de aquecimento de $10^{\circ} \mathrm{C} / \mathrm{min}$ até $1000^{\circ} \mathrm{C}$, sob fluxo de $\mathrm{N}_{2} \mathrm{UP}$, partindo da temperatura ambiente até $600 \stackrel{\circ}{\circ}$, para avaliar-se a estabilidade térmica das resinas existente no resíduo e as principais perdas de massa;

- Fração Fibra/Resina: foi determinada via conforme a norma ASTM D3171-11, "Standard Test Methods for Constituent Content of Composite Materials", Procedimento G;

- Irradiação por Micro-ondas: Os testes envolvendo o aquecimento e queima por meio da irradiação por micro-ondas foram realizados em três fornos de micro-ondas doméstico: forno marca Cônsul, modelo CMY34ARHNA, série MG1667448, de 1350 W de potência nominal, e 900 W de potência útil; forno marca $L G$, modelo MS108DD, de $1270 \mathrm{~W}$ de potência; e forno marca Sharp, modelo R4RH94, de $1550 \mathrm{~W}$ de potência nominal, e $900 \mathrm{~W}$ de potência útil. Mais detalhes sobre os equipamentos seguem apresentados no item 3.2.2. deste trabalho;

- Microscopia Ótica: A observação de detalhes com relação à disposição das camadas de compósitos, possibilitando verificar a qualidade da laminação realizada na produção dos compósitos, foi feita usando um microscópio ótico modelo Axiolmager M2m, marca Carl Zeiss. As amostras foram observadas sem preparação, de forma a serem estudadas as características superficiais obtidas pelo processamento via irradiação no micro-ondas;

- Temperatura via Termovisor para Imagens em Infravermelho: A 
avaliação de temperatura ao longo da superfície das amostras, para a verificação dos fenômenos térmicos envolvidos, foi realizada por meio de um termovisor para imagens em infravermelho modelo TG165, marca Flir, e as imagens de infravermelho obtidas foram tratadas pelo do programa Flir Quick Report 1.2, marca Flir;

- Medidas de Turbidez: A medição de turbidez das amostras foi realizada por meio de um turbidímetro modelo TD-300, marca Instruterm;

- Teor de Oxigênio Dissolvido: A medição do teor de oxigênio dissolvido foi realizada por um sensor de $\mathrm{O}_{2}$ modelo MO-900, marca Instruterm;

- Teor de Sólidos Dissolvidos (TDS), Condutividade Elétrica, pH, Salinidade e Temperatura: os cinco parâmetros supracitados foram medidos nas amostras com água por um medidor multiparâmetro modelo PCS Testr 35, marca Oakton.

\subsubsection{Fornos de Micro-ondas}

\subsubsection{Escolha dos Fornos}

A escolha de equipamentos para a realização dos ensaios foi orientada no sentido de buscar fornos comerciais (domésticos) com características semelhantes às apresentadas na literatura: médio a grande volume interno da cavidade, e alta potência de entrada, do forno (PECORARO,1997 , SANSEVERINO,2002 , KAPPE,DALLINGER,MUPHREE,2009 e THOSTENSON,CHOU,1999).

$O$ volume interno da cavidade do forno de micro-ondas influencia diretamente na forma que as micro-ondas são refletidas. $O$ resultado da reflexão das micro-ondas gera o padrão de pontos quentes e frios existentes no interior da cavidade do forno, possibilitando diferentes maneiras de aquecimento para cada tipo de cavidade. Para o presente trabalho foram escolhidos, inicialmente, dois fornos com volume médio a grande: um forno com 25 litros (marca Cônsul), e outro forno com 28 litros (marca LG). Em virtude da perda no decorrer dos ensaios do forno com 28 litros, e de falhas no funcionamento do forno com 25 litros, foi escolhido um terceiro forno com 42,5 litros (marca Sharp) para a conclusão dos ensaios.

A potência de entrada do forno é outro ponto relevante na escolha e influencia na quantidade de energia que será efetivamente transferida para o material 
irradiado. Existe considerável diferença entre a potência de entrada do equipamento, a potência de saída do emissor, e a potência disponível para ser absorvida pela amostra.

Os fornos utilizados neste estudo foram escolhidos em virtude de manter uma considerável potência de saída do emissor, possibilitando uma maior quantidade de energia para a irradiação da amostra. O forno de 25 litros escolhido, marca Cônsul, possui $1350 \mathrm{~W}$ de potência de entrada do forno, que resultam $900 \mathrm{~W}$ de potência máxima de saída do emissor. O forno de 28 litros, marca LG, possui $1270 \mathrm{~W}$ de potência, que resultam em $800 \mathrm{~W}$ de potência máxima de saída do emissor. Por outro lado, o forno de 42,5 litros, marca Sharp, possui $1550 \mathrm{~W}$ de potência de entrada, que resultam em $900 \mathrm{~W}$ de potência máxima de saída do emissor. Para efeitos de nomenclatura e notação ao longo deste trabalho, o forno de 25 litros, marca Consul, será denominado 25L, o forno de 28 litros, marca LG, 28L, e o forno de 42,5 litros, marca Sharp, será denominado 42L.

\subsubsection{Níveis de Potência e Funcionamento}

A dosagem dos níveis de potência em um aparelho de micro-ondas pode ser feita de duas formas, basicamente: com a regularem da voltagem de entrada do emissor, por meio de um variac, ou de forma mais simples, com a regularem do tempo de funcionamento do emissor.

Para equipamentos mais simples, como os escolhidos para este trabalho, o nível de potência foi determinado pelo tempo de funcionamento do emissor. Existem trabalhos indicando a adaptação de um variac em forno doméstico comum, com alterações na parte eletrônica do equipamento. Apesar disso, optou-se por manter os equipamentos como recebidos, de maneira a evitar divergir do foco deste estudo (KOK et al,1994).

Os fornos de micro-ondas escolhidos, quando ativados, emitem toda a energia disponível em seus emissores, de forma que o forno $25 \mathrm{~L}$ emite $788 \mathrm{~W}$, o forno $28 \mathrm{~L}$ emite $588 \mathrm{~W}$, e o forno $42 \mathrm{~L}$ emite $610 \mathrm{~W}$. De forma a determinar a forma de funcionamento dos níveis de potência de ambos os fornos, foi realizada verificação do tempo de ativação dos emissores de micro-ondas. O monitoramento foi realizado para cada nível de potência 


\subsubsection{Calibração}

O procedimento de calibração foi realizado conforme o indicado pela literatura (PECORADO,1997). A potência de saída do emissor pôde ser determinada indiretamente pela medida do aumento de temperatura, em graus Celsius, para um litro de água aquecido por dois minutos. A precisão das medidas depende do posicionamento do volume de água (sempre na mesma posição dentro da cavidade), e da utilização do mesmo frasco para conter o volume de água. A potência pode ser medida pela Equação 1 :

\section{Equação $1: \mathrm{P}=\mathrm{Cp} \mathrm{K} \Delta \mathrm{T} \mathrm{m} / \mathrm{t}$}

Em que $\mathrm{P}$ é a potência absorvida pela água (Watts), $\mathrm{K}$ é o fator de conversão de calorias para Watts, Cp é a capacidade calorífica (cal ${ }^{\circ} \mathrm{C}$ ), $\mathrm{m}$ é a massa da amostra (g), e t é o tempo (s).

Após a calibração dos fornos, foram obtidos os resultados mostrados na Figura 18. $\mathrm{O}$ forno $28 \mathrm{~L}$ apresentou menor capacidade de fornecer energia para a amostra irradiada. Em comparação entre fornos, o forno $28 \mathrm{~L}$ apresentou $588 \mathrm{~W}$ de potência, enquanto o forno $25 \mathrm{~L}$ apresentou $788 \mathrm{~W}$. O forno $42 \mathrm{~L}$ apresentou $610 \mathrm{~W}$ de potência. Também é possível notar que a distribuição da potência irradiada varia quase linearmente para os três fornos, mantendo proporção nos diferentes níveis de potência.

Figura 18 - Calibração de potência irradiada pelos fornos de micro-ondas

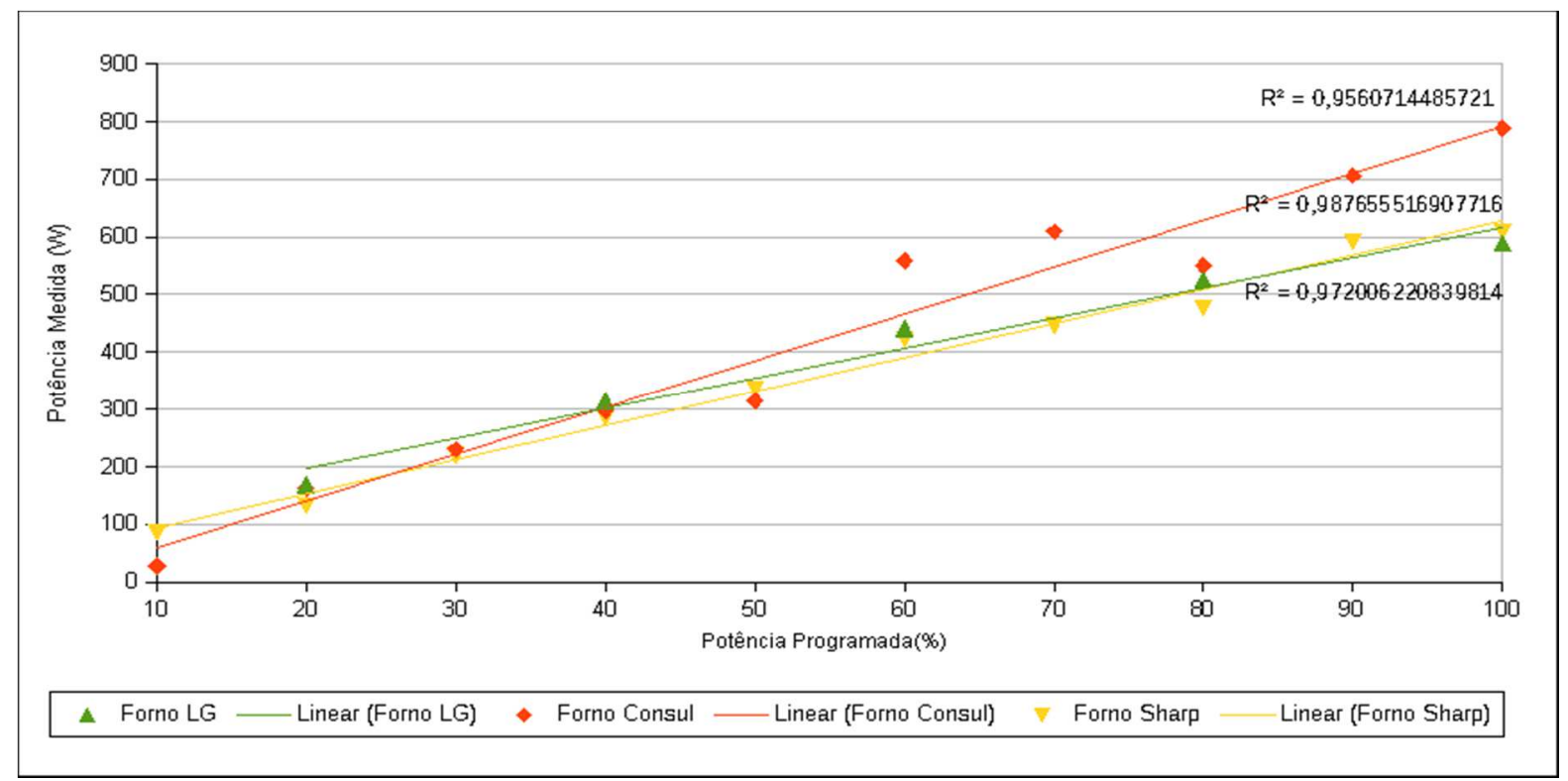

Fonte: Kersting, 2019. 


\subsubsection{Avaliação de Pontos Quentes na Cavidade do Forno}

A avaliação de pontos quentes na cavidade do forno foi realizada pela da obtenção de informações com termoimagens em infravermelho. Este tipo de avaliação é de grande importância, pois indica o ponto na base da cavidade do forno ao qual ocorre o principal ponto quente.

No interior do forno de micro-ondas, geralmente é instalado um prato a base de vidro refratário, com suportes em material termoplástico (PPS). Este prato é giratório e atua alterando a posição do que se quer irradiar com relação aos pontos de maior intensidade de energia, para uma melhor homogeneidade de aquecimento, (THOSTENSON,CHOU,1999). Os suportes encontram-se isolados de contato com a amostra para teste, restando apenas a avaliação do prato de vidro. Até mesmo em exposições de curta duração são verificadas diferenças no perfil térmico do prato submetido a aquecimento. Conforme pode ser observado na Figura 19, ocorreu a formação de pontos quentes a níveis de potência medianos, o que influencia diretamente no resultado final que se quer obter.

Figura 19 - Termoimagem em Infravermelho de prato de vidro refratário aquecido por 1 minuto em forno de micro-ondas comercial, com potência mediana: ponto quente marcado com $45,6 \stackrel{\circ}{ } \mathrm{C}$

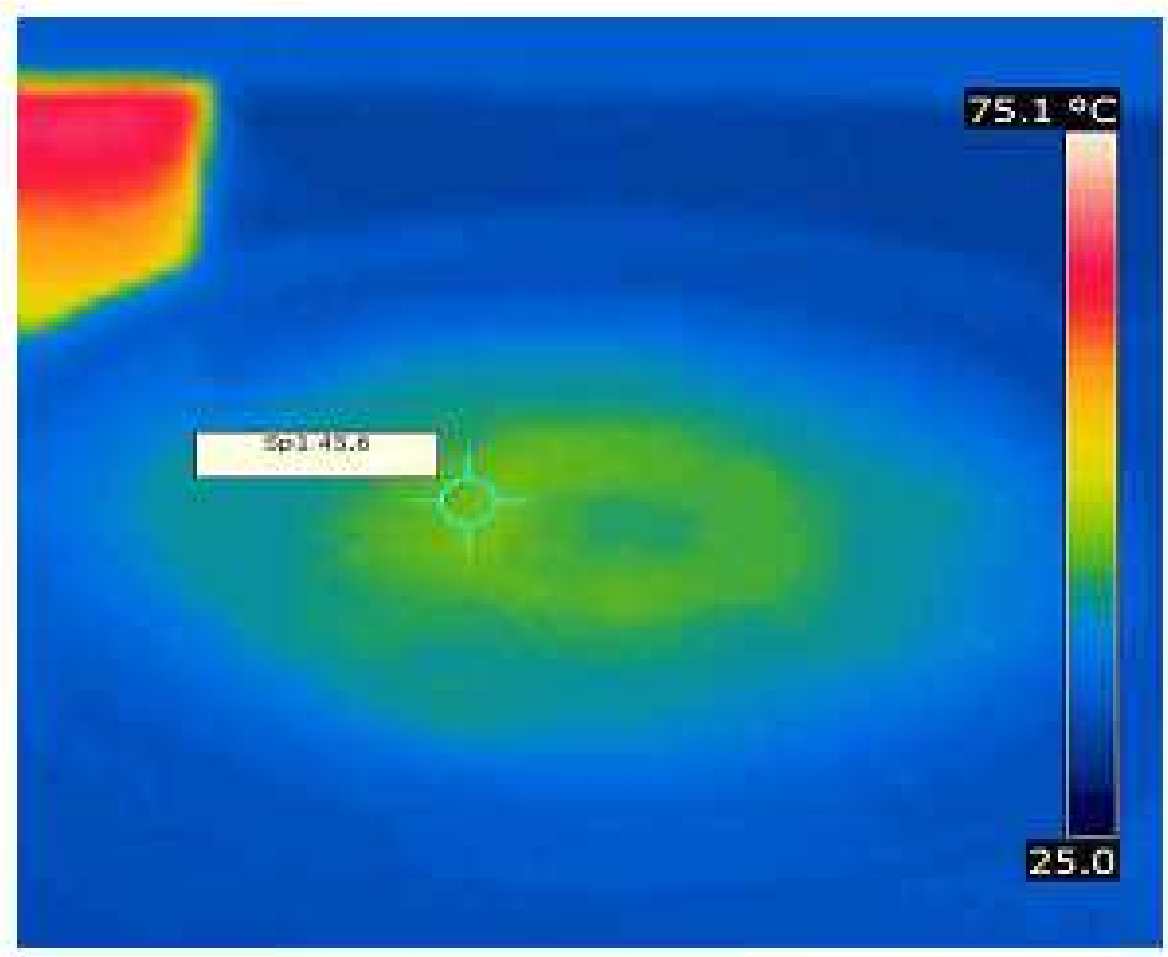

Fonte: Thostenson,Chou,1999). 
O aquecimento do prato de vidro refratário indicou que o prato concorre com a amostra na absorção de energia irradiada pelo forno de micro-ondas, e indicou também que pode ocorrer aquecimento por condução térmica simples, dependendo da intensidade e tempo de irradiação da amostra. Na Figura 20 são mostradas imagens obtidas para o forno $25 \mathrm{~L}$.

Figura 20 - Termoimagens em infravermelho do prato refratário do forno $25 \mathrm{~L}$, com $400 \mathrm{~g}$, aquecido por 1 minuto, no nível de potência 100: antes (esquerda), e após aquecimento (direita).

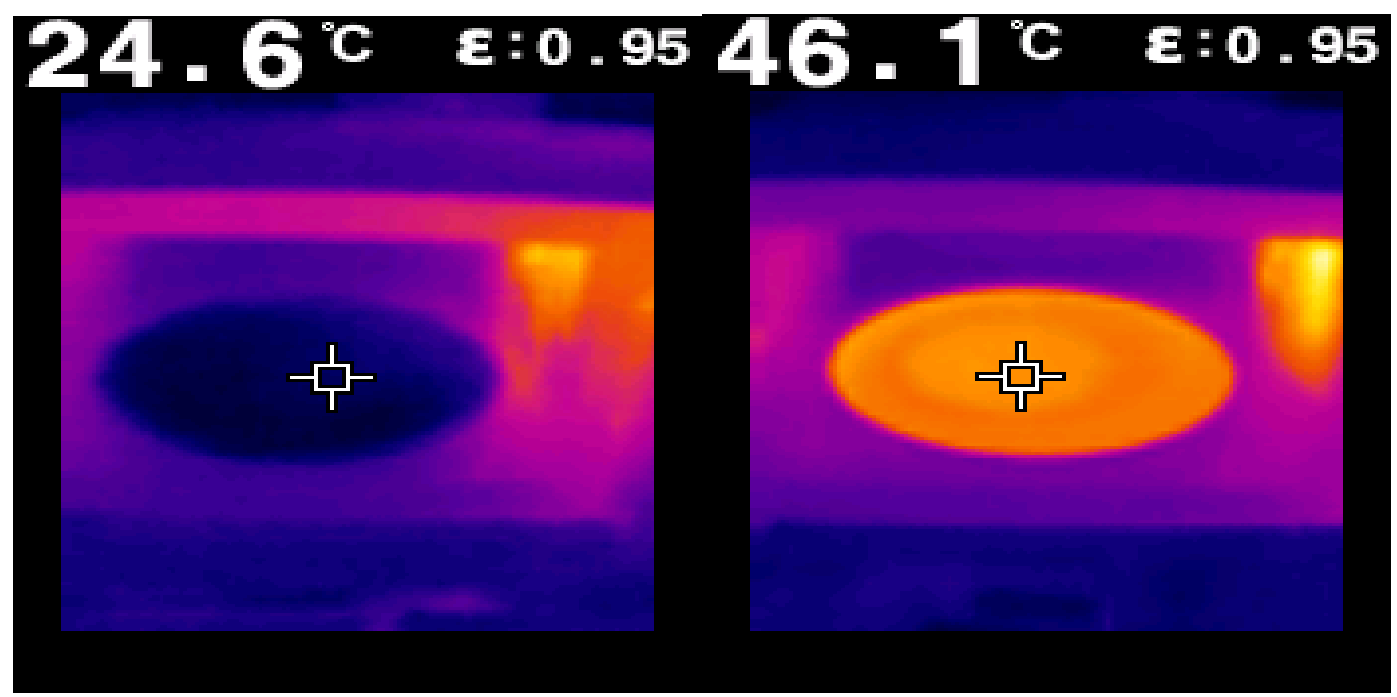

Fonte: Kersting,2019.

Visando contornar os dois fatores expostos anteriormente, foram utilizados meios de minimizar ou anular os efeitos proporcionados pelo aquecimento do prato de vidro refratário (THOSTENSON,CHOU,1999):

- uso de material transparente a micro-ondas, com bom isolamento térmico (minimizar a condução térmica do prato), suportado diretamente sobre o prato de vidro refratário (alumina); e

- troca do prato refratário por outro material com boa estabilidade dimensional, sem deformar-se ao calor das micro-ondas por irradiação prolongada. 


\section{RESULTADOS E DISCUSSÃO}

\subsection{TESTES PRELIMINARES}

\subsubsection{Caracterização do Resíduo}

\subsubsection{Teor de Fibra}

A medição da fração fibra/resina real foi determinada conforme indicado pela norma ASTM D3171-11. O valor médio da fração de resina foi de 36,1\% aproximadamente.

\subsubsection{Microscopia Ótica}

A avaliação via microscopia ótica permitiu verificar a condição das fibras como recebidas. Na Figura 21, é possível observar as fibras de vidro associadas em feixes de fibras de tamanhos reduzidos, o que indicou a presença de resina epóxi mantendo as mesmas reunidas.

Figura 21 - Imagens obtidas via microscopia ótica: no alto a esquerda 5X, no alto a direita 10X, e logo abaixo $20 \mathrm{X}$ de aumento

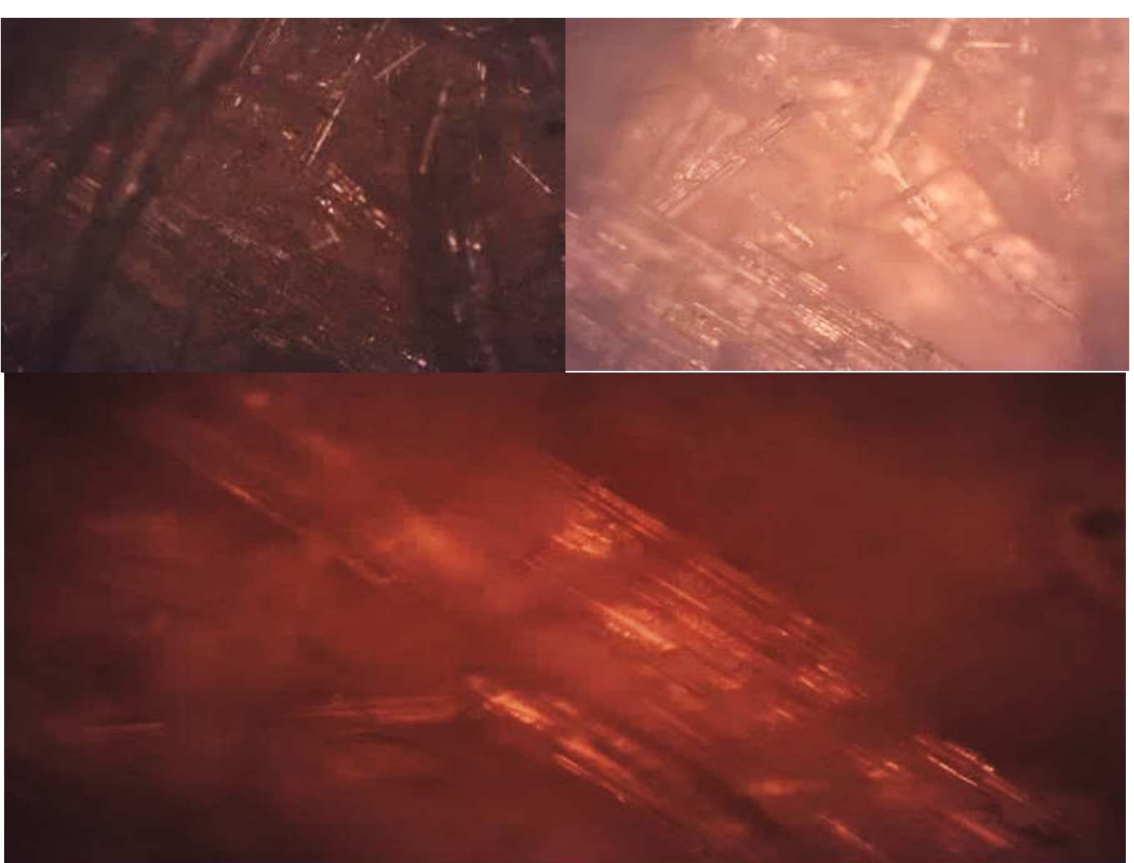




\subsubsection{Análise Termogravimétrica}

Em complemento a medição da fração fibra/resina foram realizados ensaio de análise termogravimétrica com o material como recebido. Apesar do resíduo apresentar uma granulometria relativamente uniforme, a execução dos ensaios de análise termogravimetria ficou dificultada.

As amostras para a realização do ensaio devem ser da ordem de $10 \mathrm{mg}$ de massa, o que dificultou uma amostragem efetiva. Os ensaios foram repetidos, de forma a buscar-se um resultado representativo, mas sem sucesso. De modo geral, foram verificadas duas perdas de massa principais: a primeira a partir de $300^{\circ} \mathrm{C}$, com aproximadamente $31 \%$ de perda, e a segunda a partir de $395^{\circ} \mathrm{C}$, com aproximadamente $34 \%$ de perda. Em média, os resultados obtidos seguem 0 observado na medição de fração fibra/resina.

As temperaturas onde foram verificadas as perdas de massa vem em linha com o observado para a degradação de resinas epóxi. As perdas de massa possivelmente refletem os tipos de resinas epóxi usados para a fabricação do compósito original, mas mais estudos sobre a fração orgânica do resíduo seriam necessários, divergindo do objetivo deste trabalho.

\subsubsection{Avaliação Inicial como Elemento Filtrante: Resíduo}

As perspectivas iniciais do trabalho indicavam a possibilidade da utilização do resíduo de fibra de vidro com resina epóxi, na forma de pó, como uma alternativa de substituição da areia em aplicações na área de filtração e afins. A natureza química bastante similar (tanto a areia quanto a fibra no resíduo são grande parte $\mathrm{SiO}_{2}$ ), bem como fato da resina epóxi contida no resíduo estar curada, e em uma condição inerte quimicamente (nas condições ambientais de temperatura e pressão), indicavam este fim.

Na Figura 22, é possível observar o resultado do teste realizado usando o resíduo como elemento filtrante. Visualmente, é possível perceber a redução na turbidez da água-teste utilizada. O presente resultado qualifica o uso do resíduo 
fornecido pela Wobben como um bom pré-filtro, com possibilidade de uso nas mesmas condições de outros produtos equivalentes (como a própria areia, por exemplo).

Figura 22 - Comparação entre o filtrado obtido a partir do uso do resíduo como elemento filtrante (ao centro), com água destilada (à esquerda), e com água-teste (à direita).

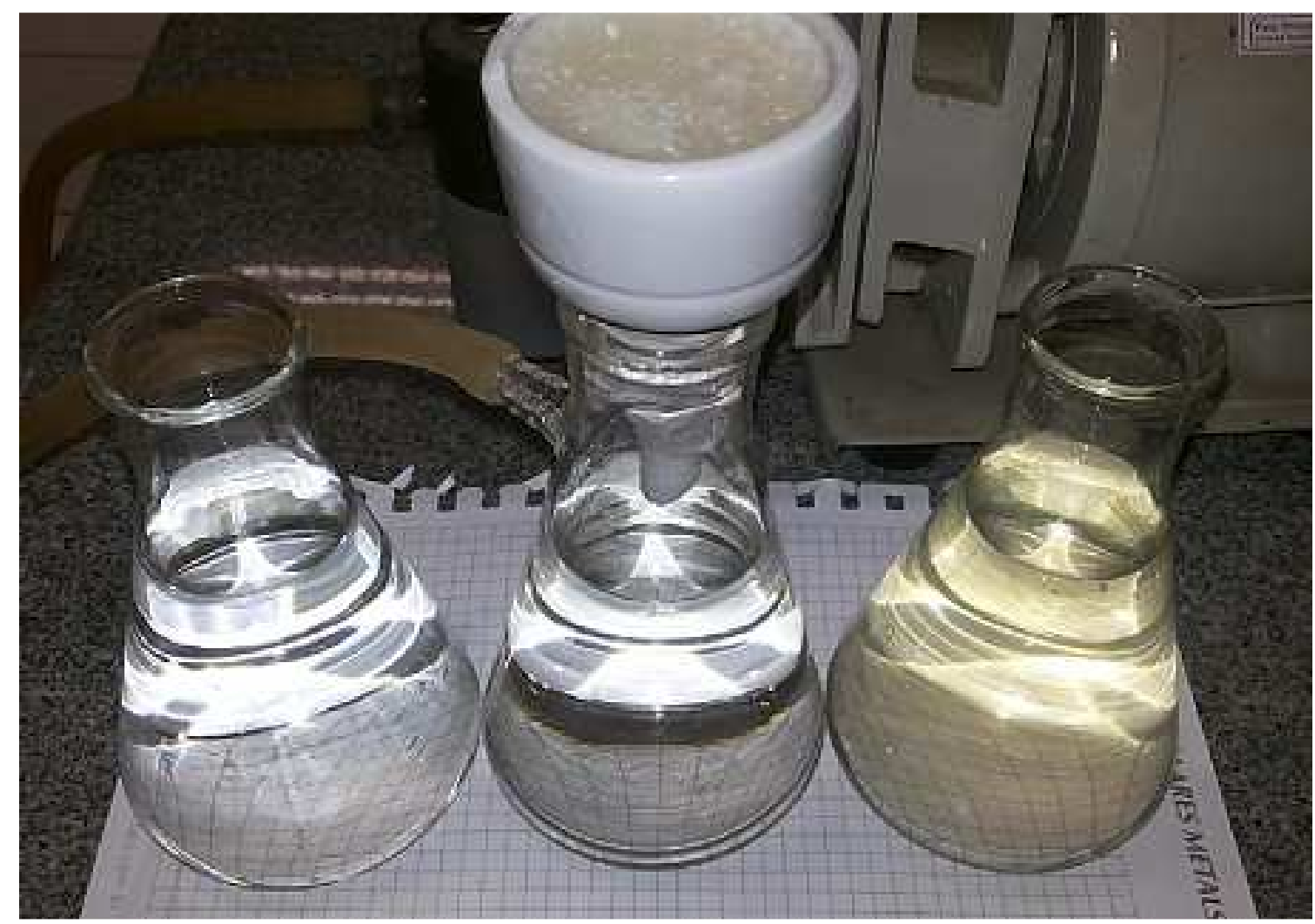

Fonte: Kersting,2019.

Para afastar a possibilidade do filtrado obtido a partir do uso do resíduo, como elemento filtrante, apresentar algum nível de produtos químicos solubilizados, foi realizada extração à quente com água destilada, por 25 minutos, a $90 \stackrel{\circ}{ } \mathrm{C}$. A proporção utilizada entre resíduo e água destilada foi de 1:10, definida de forma a obter-se um extrato rico nos produtos solúveis em água contidos no resíduo, e permitir que a mistura fosse agitada mecanicamente. O principal objetivo para este procedimento foi obter uma solução contendo potenciais produtos orgânicos para confirmar a existência de contaminantes contidos no resíduo fornecido pela Wobben.

Após a obtenção do extrato, o mesmo foi avaliado via FTIR, de forma a indicar a presença de produtos orgânicos solubilizados. O resultado obtido foi comparado com a água destilada, e as diferenças foram mínimas, não oferecendo respostas conclusivas quanto ao uso do resíduo sem o devido tratamento. Na Figura 23, são mostrados os resultados de FTIR obtidos. 
Em face ao resultado obtido ser inconclusivo, a necessidade da realização de tratamento químico do resíduo tornou-se indispensável. Neste sentido surgiu a possibilidade do uso de irradiação por micro-ondas como uma das alternativas. A principal incerteza é motivada a partir do que pode estar contido no resíduo, e que não pode ser detectado, e neste sentido o uso de micro-ondas associado a um absorvedor de irradiação, para a calcinação do resíduo, tornou-se uma possibilidade promissora.

Figura 23 - Espectros de FTIR do extrato rico obtido do resíduo (acima), e água destilada (abaixo).
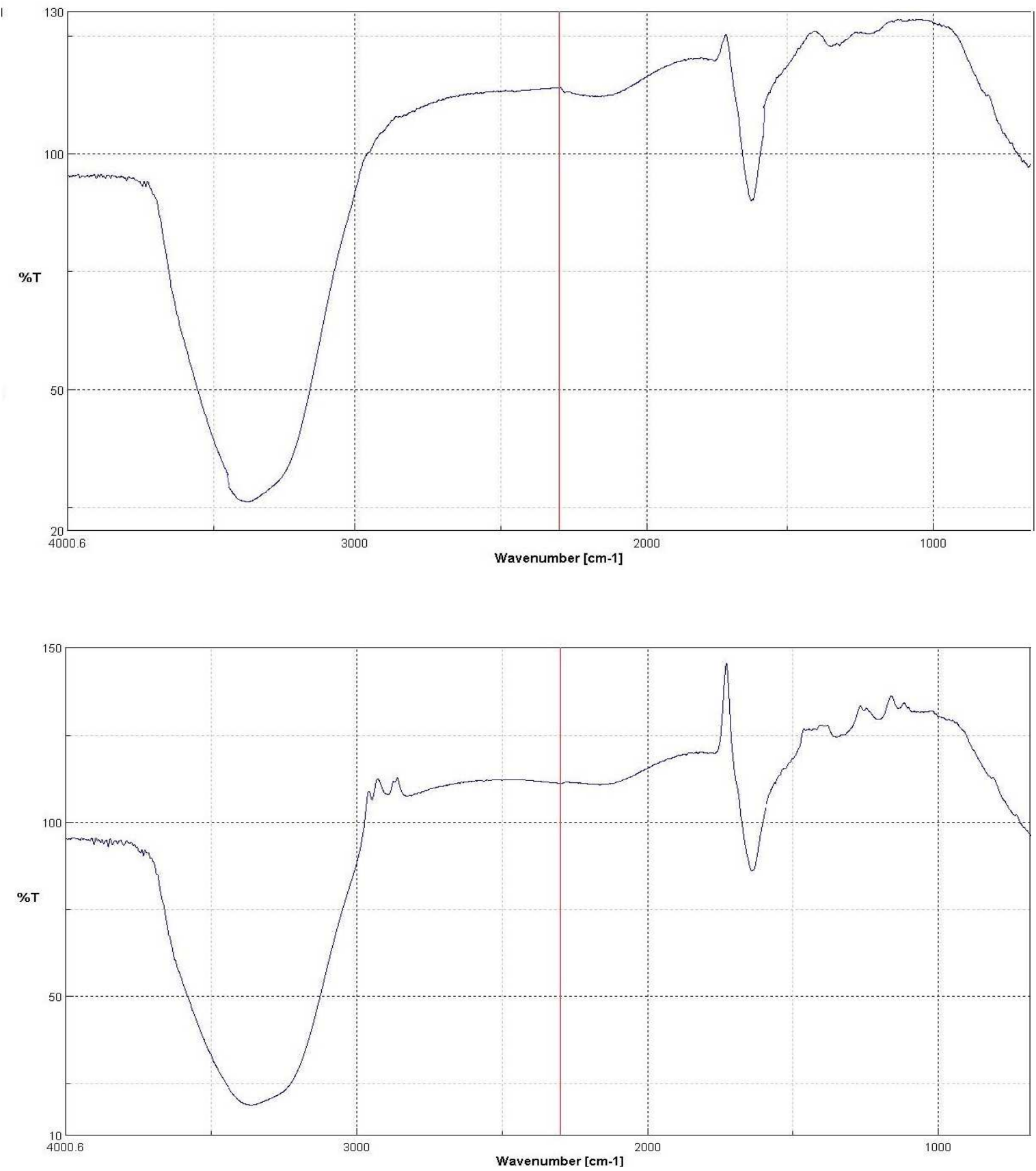

Fonte: Kersting,2019. 
Dentre os materiais com boa a excelente capacidade de absorção de irradiação de micro-ondas tem-se o carvão ativado, a alumina ativada e zeólita, que podem atuar na queima da fase orgânica do resíduo, absorvendo eventualmente parte dos produtos liberados durante o processo de carbonização. Neste sentido, faz-se necessário determinar quais temperaturas podem ser obtidas a partir de combinações de nível de potência e tempo de irradiação em um forno de micro-ondas doméstico para ambos materiais, considerando que as temperaturas para a degradação de resinas epóxi comerciais encontram-se na faixa de 250 a $400{ }^{\circ} \mathrm{C}$ (ODIAN,1991 STEVENS,1999 e MURPHY,1998).

\subsection{PROCESSAMENTO POR IRRADIAÇÃO DE MICRO-ONDAS}

\subsubsection{Avaliação de Absorção de Energia sob Irradiação}

Em estudos presentes na literatura consultada (KERSTING,2014 e PICKLES,2004), a energia absorvida foi estimada indiretamente por meio de medidas de temperaturas antes e depois da irradiação com micro-ondas. Pequenas quantidades de cada materiais a ser avaliado (1,5 g, aproximadamente) foram colocadas em recipientes com capacidade baixa de absorver micro-ondas. Cada amostra foi espalhada de forma a ter no máximo $1 \mathrm{~mm}$ de espessura, e irradiada por 1 minuto, em níveis de potência de 10 a 100\%, no forno 25L. Na Figura 24, são mostrados os resultados indicando as variações de temperatura obtidas para os materiais absorvedores utilizados no trabalho.

Os resultados obtidos confirmaram uma melhor capacidade de absorção de micro-ondas pelo carvão ativado em comparação com a alumina ativada e zeólita. Para a alumina ativada e a zeólita foi verificada uma capacidade de absorção menor, e que segue em linha com o observado em outros trabalhos (KERSTING,2014 e PICKLES,2004). 
Figura 24 - Gráficos com variação de temperaturas obtidas para a zeólita e alumina ativ. (acima), e carvão ativado (abaixo) após aquecimento. por 1 minuto, em níveis de potência de 10 a 100, no forno $25 \mathrm{~L}$.
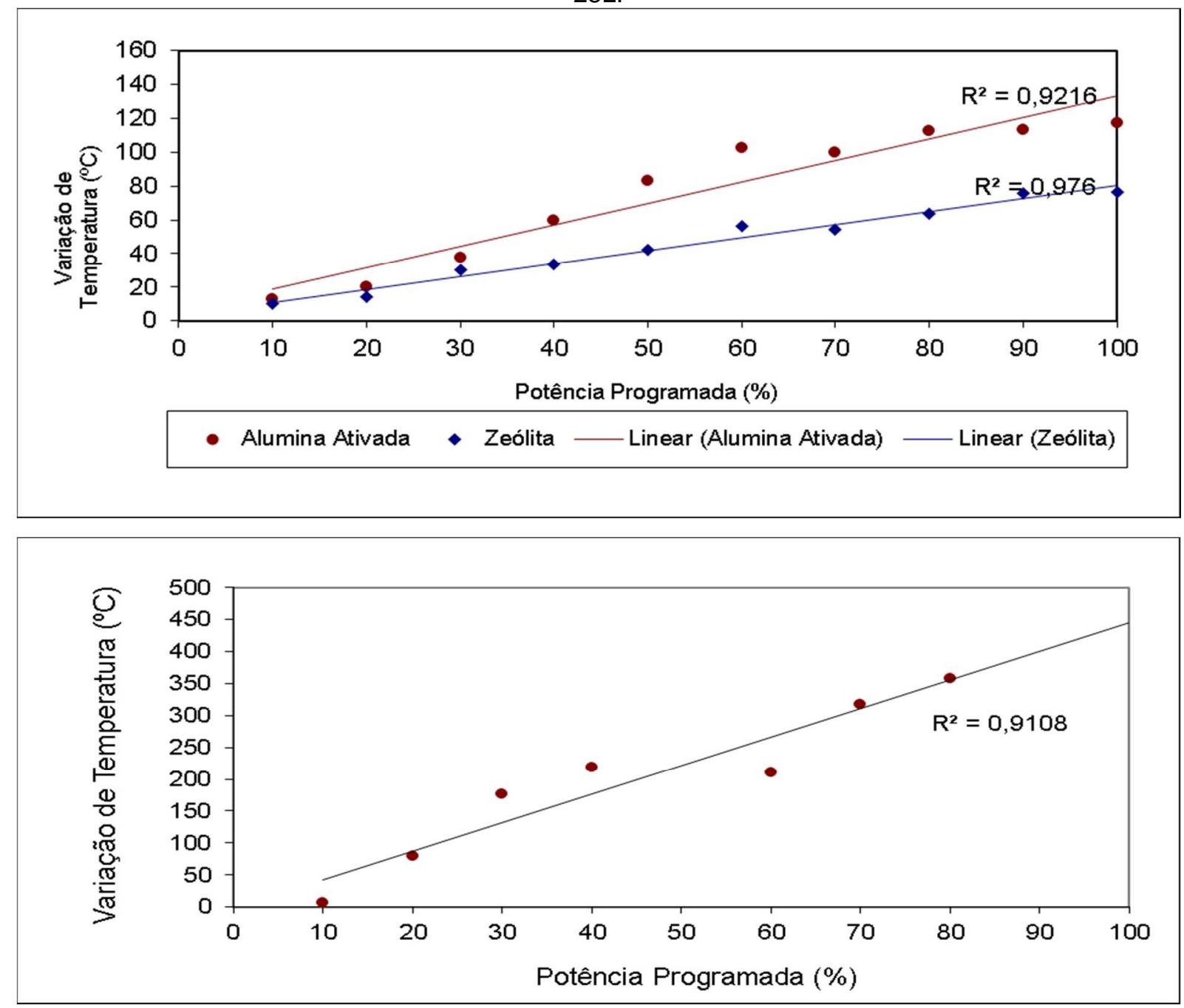

Fonte: Kersting,2019.

Adicionalmente também foi avaliado o resíduo, de maneira a confirmar a necessidade dos absorvedores de irradiação de micro-ondas para que a queima do material ocorra.

De forma a obter o tempo mínimo necessário para que a faixa de temperatura requerida fosse alcançada, foram executados novos testes, mantendose o nível de potência em 100, e medindo-se o tempo necessário. Infelizmente esta medida mostrou-se pouco eficaz pois os fornos $28 \mathrm{~L}$ e $25 \mathrm{~L}$ começaram a falhar em face ao longo tempo de operação para atingir temperaturas da ordem de $300 \stackrel{\circ}{\mathrm{C}}$, para a alumina ativada, para a zeólita, e para o resíduo. O forno $28 \mathrm{~L}$ acabou por queimar seu emissor, tendo de deixar de ser usado. O forno $25 \mathrm{~L}$ seguiu sendo usado, mas também apresentou falhas intermitentes, oferecendo dificuldades de operação. Os resultados obtidos serão apresentados no item 4.2.2. 


\subsubsection{Degradação do Resíduo com Carvão Ativado via Irradiação de Micro- ondas}

Considerados os resultados obtidos com relação à necessidade de absorvedores de micro-ondas, foram realizados testes com o forno $28 \mathrm{~L}$ para avaliação da degradação do resíduo, sob aquecimento controlado. Os novos testes foram conduzidos utilizando o nível de potência máximo, variando-se o tempo conforme exposto na Tabela 7, onde são mostrados resultados obtidos com o processamento apenas do resíduo.

Tabela 7 - Variação de massa antes e após o processamento apenas com o resíduo

\begin{tabular}{ccccc}
\hline Tempo (min.) & $\mathbf{M}_{\text {inicial }}(\mathbf{g})$ & $\mathbf{M}_{\text {final }}(\mathbf{g})$ & Variação & \% Variação \\
\hline 1 & 9,02 & 9,00 & 0,02 & 0,2 \\
5 & 9,85 & 9,78 & 0,07 & 0,7 \\
10 & 9,51 & 9,47 & 0,04 & 0,4 \\
$* 20$ & 10,05 & 9.53 & 0,52 & 5,2 \\
$* 30$ & 9,83 & 9,15 & 0,68 & 6,9 \\
\hline
\end{tabular}

Obs: * resíduo começou a queimar.

Fonte: Kersting,2019.

Como observado inicialmente nas medições de temperatura após irradiação, o resíduo sem absorvedores atingiu temperaturas menores quando irradiado, e começou a queimar apenas depois de submetido a uma exposição mais prolongada. Como pode ser observado na Tabela 7, apenas após 20 minutos de irradiação de micro-ondas o resíduo começou a queimar. De forma a comparar o comportamento com os absorvedores, o mesmo teste foi realizado com o carvão ativado. O carvão ativado foi escolhido em virtude de estar na forma de pó, e esta condição permitiu uma melhor mistura com o resíduo quando testados ambos, na mesma mistura. Os resultados seguem apresentados na Tabela 8.

Tabela 8 - Variação de massa antes e após o processamento apenas com o carvão ativado

\begin{tabular}{ccccc}
\hline Tempo (min.) & $\mathbf{M}_{\text {inicial }}(\mathbf{g})$ & $\mathbf{M}_{\text {final }}(\mathbf{g})$ & Variação & \% Variação \\
\hline 1 & 4,23 & 3,68 & 0,55 & 13,0 \\
5 & 4,72 & 3,52 & 1,20 & 25,3 \\
10 & 4,77 & 3.02 & 1,75 & 36,7 \\
20 & 4,78 & 2,19 & 2,59 & 54,2 \\
30 & 4,76 & 1,98 & 2,78 & 58,4 \\
\hline
\end{tabular}

Fonte: Kersting,2019. 
Em face da capacidade de absorção de micro-ondas já medida pelo meio de variação de temperatura, o teste confirmou a capacidade de aquecimento do carvão ativado, e a sua perda de massa por queima do material, conforme pode ser visto na Tabela 8. Por fim foi realizado o teste com a mistura do resíduo com o carvão ativado. Para fins de começo dos testes, foi considerado o teor de fibra de vidro/resina epóxi, 63,9/36,1. A quantidade de absorvedor usada inicialmente foi de $36,1 \%$ em massa, em relação ao total de resíduo a ser processado por irradiação de micro-ondas. Os resultados obtidos seguem na Tabela 9.

Tabela 9 - Variação de massa antes e após o processamento com mistura de resíduo/carvão ativado

\begin{tabular}{ccccc}
\hline Tempo (min.) & $\begin{array}{c}\mathbf{M}_{\text {inicial }}(\mathbf{g}) \text { (resíduo } \\
\text { + carvão ativado) }\end{array}$ & $\mathbf{M}_{\text {final }}(\mathbf{g})$ & Variação & \% Variação \\
\hline 1 & $9,51+3,46$ & 11,42 & 1,14 & 8,79 \\
5 & $9,54+3,42$ & 9,66 & 1,20 & 9,26 \\
10 & $9,54+3,41$ & 9,05 & 1,75 & 13,50 \\
20 & $9,53+3,43$ & 8,24 & 2,59 & 19,98 \\
30 & $9,51+3,42$ & - & - & - \\
\hline
\end{tabular}

Fonte: Kersting,2019.

A forma de verificar se toda a fase orgânica do resíduo (resina epóxi e outros componentes) foi calcinada foi realizando a medida da variação de massa antes e depois do processamento. Caso a perda de massa obtida ao final do teste for superior a 36,1\% será considerado que toda a fase orgânica foi consumida.

Para os ensaios realizados, considerando que a fase orgânica queima simultaneamente junto com o aquecimento do absorvedor, que também está sujeito a queima, serão necessários novos testes com tempo mais prolongado para a devida confirmação. Adicionalmente, ocorreu superaquecimento do irradiador do microondas (magnetron) para o ensaio de 30 minutos, confirmando a necessidade de mais testes.

Apesar de outros ensaios serem necessários, outros aspectos observados no ensaio indicaram que a opção está correta. No decorrer dos ensaios de 20 e 30 minutos, realizados com as misturas resíduo/carvão ativado, os recipientes utilizados foram ao rubro. Na Figura 25 é mostrada a imagem do forno $28 \mathrm{~L}$ obtida ao final do teste de 20 minutos, no nível de potência máximo do forno. 
Figura 25 - Foto do ensaio de carbonização da mistura resíduo e carvão ativado, ao final do ensaio de 20 minutos, no nível de potência máximo do forno $28 \mathrm{~L}$.

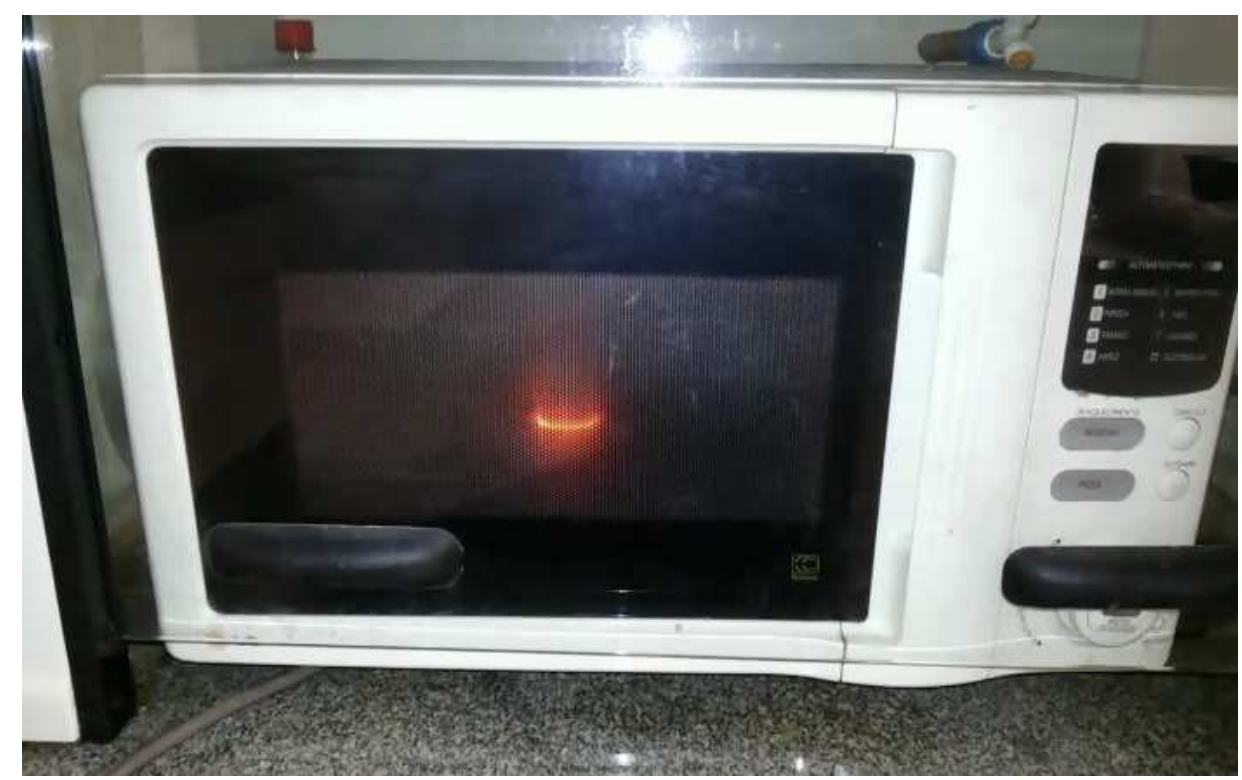

Fonte: Kersting,2019.

Cabe acrescentar que além da condição exposta anteriormente, a amostra irradiada liberava pouca fumaça durante o seu processamento, o que indicou que boa parte do material já havia sido consumido. Considerados os dados obtidos para a perda de massa, foi possível realizar um gráfico no qual foi sugerido o tempo mínimo para que a perda de massa obtida seja superior a 36,1\%. No gráfico mostrado na Figura 26, e a regressão linear realizada, para se obter pelo menos $36,1 \%$ de perda de massa serão necessários pelo menos 46,2 minutos do forno $28 \mathrm{~L}$ em operação.

Figura 26 - Gráfico perda de massa (\%) versus tempo, para teste com forno $25 \mathrm{~L}$

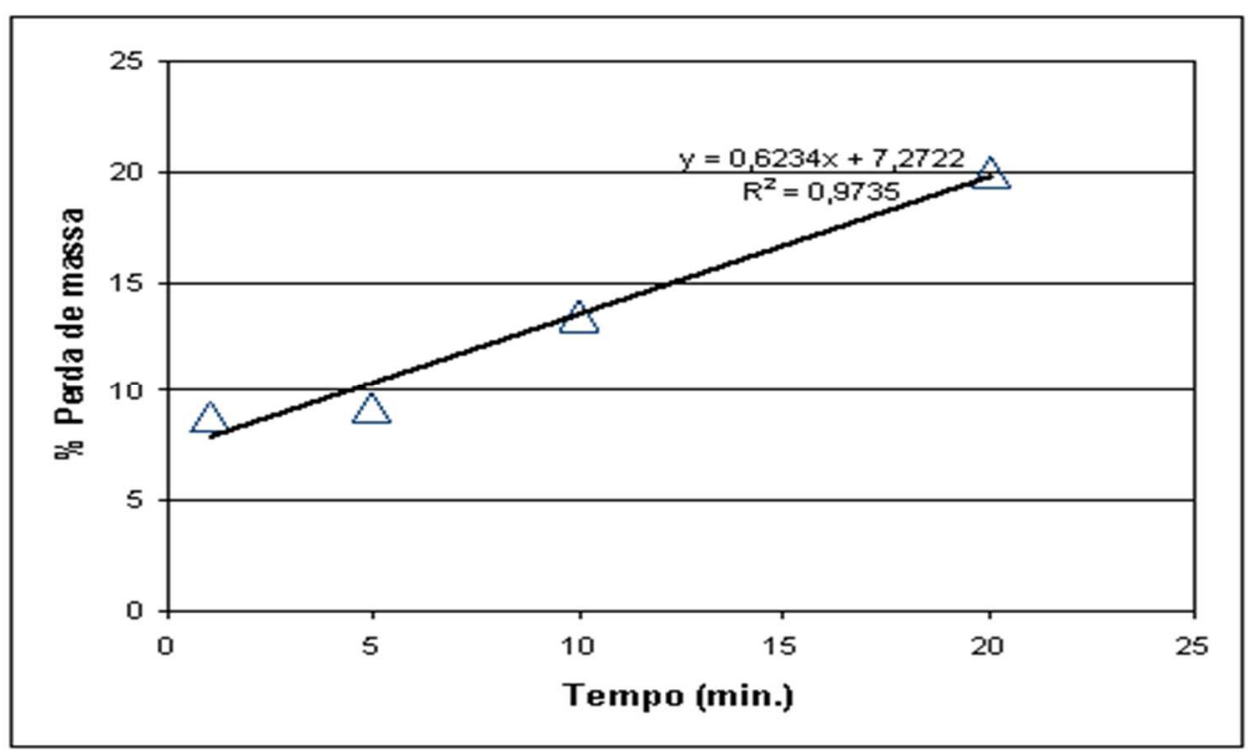

Fonte: Kersting,2019. 


\subsubsection{Avaliação Inicial como Elemento Filtrante: Resíduo Processado com Carvão Ativado via Irradiação de Micro-ondas}

O produto do processamento via irradiação de micro-ondas, com a presença de carvão ativado, obtido a partir do teste de 20 minutos de duração, e nível de potência máximo do forno $28 \mathrm{~L}$ foi testado como elemento filtrante. A amostra de água-teste foi obtida após coleta em cursos de água na cidade de Sorocaba. Na Figura 27 é mostrada a preparação do elemento filtrante e o resultado obtido após a filtração.

Figura 27 - Preparação do elemento filtrante para teste de capacidade de filtração do resíduo processado via irradiação de micro-ondas (esquerda), e filtrado obtido após a filtração com elemento filtrante produzido a partir do resíduo processado com carvão ativado (direita)
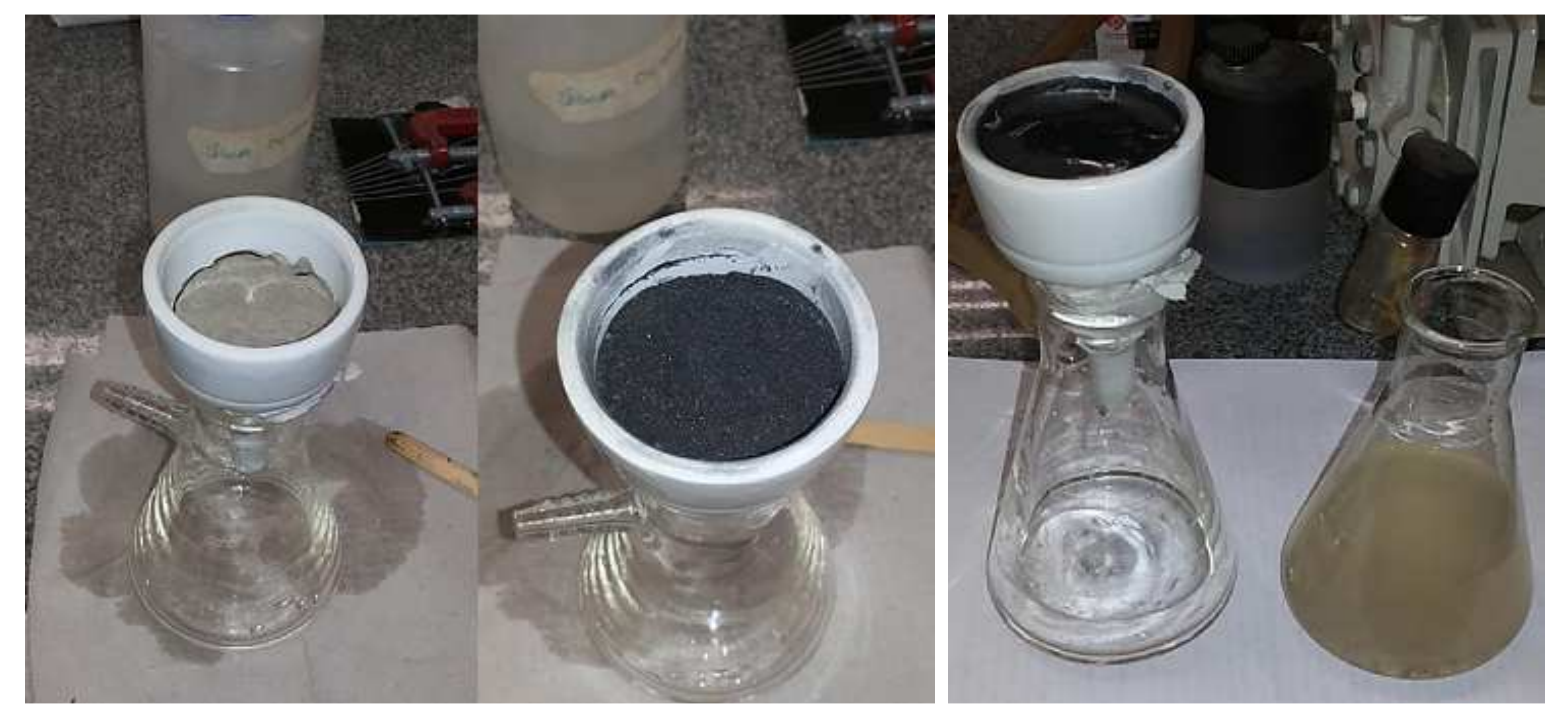

Fonte: Kersting, 2019.

Para evidenciar as mudanças ocorridas na água filtrada, além da alteração visual, os seguintes parâmetros foram observados, como apresentado na Tabela 10.

Tabela 10 - Avaliação comparativa entre água-teste e filtrado obtido

\begin{tabular}{ccc}
\hline Parâmetro & Água-teste & Filtrado Obtido \\
\hline Condutividade Elétrica (S/cm) & 461 & 441 \\
pH & 7,7 & 8,3 \\
TDS (ppm) & 327 & 314 \\
Turbidez (NTU) & 49,35 & 1,94 \\
Teor de $\mathrm{O}_{2}\left(\% \mathrm{O}_{2}\right.$ dissolvido) & 2,90 & 11,14 \\
Teor de Sais (ppm) & 221 & 212 \\
\hline
\end{tabular}

Obs: TDS - teor de sólidos dissolvidos

NTU - nephelometric turbity unit

Fonte: Kersting,2019. 
Conforme mostrado, e verificado na Figura 27, ocorreu drástica variação na turbidez. Os demais fatores apresentaram pequena alteração, indo ao encontro do efeito da presença de carvão ativado. O carvão ativado reteve parte dos sais e sólidos dissolvidos, reduzindo a condutividade elétrica da água obtida após a filtração com o elemento filtrante produzido após processamento com irradiação de micro-ondas, na presença de carvão ativado. Os resultados apresentados reforçam o constatado inicialmente nos testes preliminares, indicando o uso do resíduo fornecido pela Wobben, sem ou com processamento, como pré-filtro para tratamento de água.

\subsection{FILTRAÇÃO COM USO DA ÁGUA DO RIO IPANEMA - IPERÓ/SP}

\subsubsection{Elementos Filtrantes Utilizados na Filtração}

Para a realização dos ensaios de filtração foram utilizados os seguintes elementos filtrantes: resíduo simples (como recebido da Wobben), resíduo tratado em mufla a gás, resíduo processado com carvão ativado e irradiação de micro-ondas, e carvão ativado, alumina ativada, e zeólita, como recebidos.

Os elementos filtrantes que envolveram o uso do resíduo foram preparados de forma a avaliar diferentes condições de processamento, para fins de comparação com os demais materiais usados em processos industriais de tratamento de água. Para efeitos dos ensaios também foi realizada a tentativa de processamento do resíduo com carvão ativado, em mufla a gás, para uso nos testes de filtração. Diferente do esperado, esta forma de processamento apresentou dificuldades em se mostrar viável dentro da proposta deste trabalho, como será exposto no item 4.3.1.2. (LIBÂNIO,2010).

\subsubsection{Elemento Filtrante a partir do Tratamento Térmico do Resíduo em Mufla a Gás}


O resíduo original, fornecido pela Wobben nos primeiros ensaios de determinação de fração fibra/resina, indicou a presença de cerca de 36,1\% em massa de materiais orgânicos. Pelo fato desta fração de materiais orgânicos ser relevante em termos de quantidade, foi produzido material sem a presença desta fração, a fim de serem medidos apenas os efeitos da fibra de vidro constante no resíduo em experimento de filtração.

O resíduo foi acondicionado em um cadinho refratário, e colocado em uma mufla com aquecimento a gás, alimentada por GLP, até que fosse observada a queima completa do resíduo. O final do tratamento do resíduo, com a degradação da fase orgânica, foi medido em uma balança, e aferido visualmente, com a obtenção ao final do processo, de um pó branco levemente rosado. O tratamento térmico do resíduo foi encerrado quando a perda de massa medida se tornou constante, com uma perda de massa de aproximadamente $35 \%$. O tempo total de tratamento térmico foi de aproximadamente 90 minutos.

\subsection{Caracterização}

\subsection{Microscopia Ótica}

Figura 28 - Imagens obtidas via microscopia ótica: no alto a esquerda 5X, no alto a direita 10X, e logo abaixo a esquerda 20X, e abaixo a direita 50X de aumento.

Fonte: Kersting,2019.

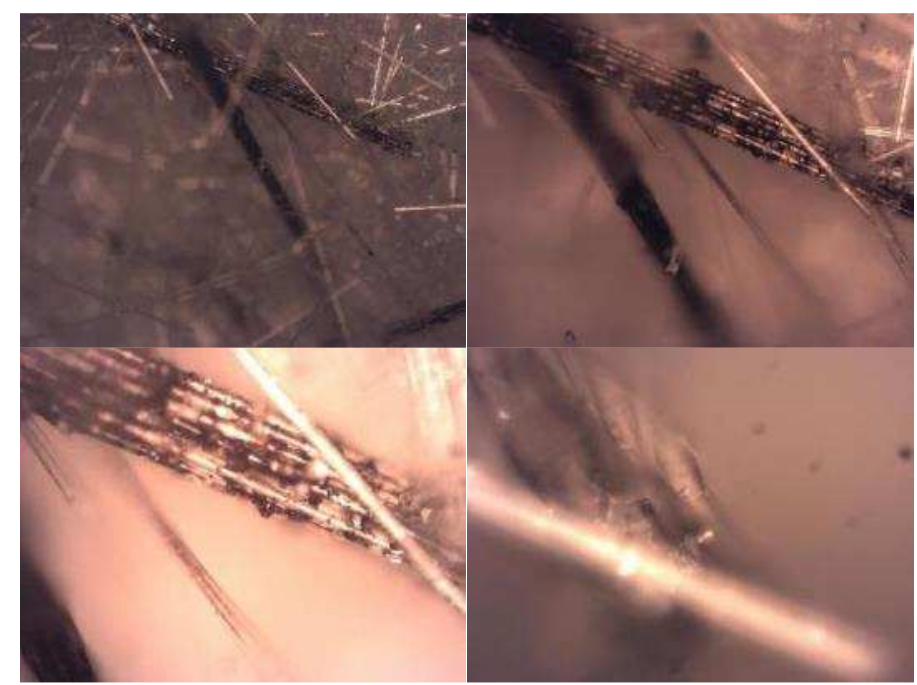


A avaliação via microscopia ótica permitiu verificar a condição das fibras após o tratamento térmico em mufla. Na Figura 28 é possível observar as fibras de vidro associadas em feixes de fibras de tamanhos reduzidos, com pontos escuros, o que indicou que o tratamento térmico foi efetivo, restando pouco material da fase orgânica associado.

\subsection{Análise Termogravimétrica}

Em complemento a Microscopia Ótica foi realizado ensaio de análise termogravimétrica após o tratamento do resíduo em mufla a gás. $O$ tratamento térmico do resíduo em mufla foi plenamente efetivo, sem perdas de massas relevantes, confirmando o observado nos ensaios de microscopia ótica. A fração orgânica existente originalmente no resíduo fornecido foi retirada, restando traços de material ainda misturados a amostra, conforme pode ser observado na Figura 29.

Figura 29 - Análise termogravimétrica para amostra de resíduo tratada por mufla a gás.

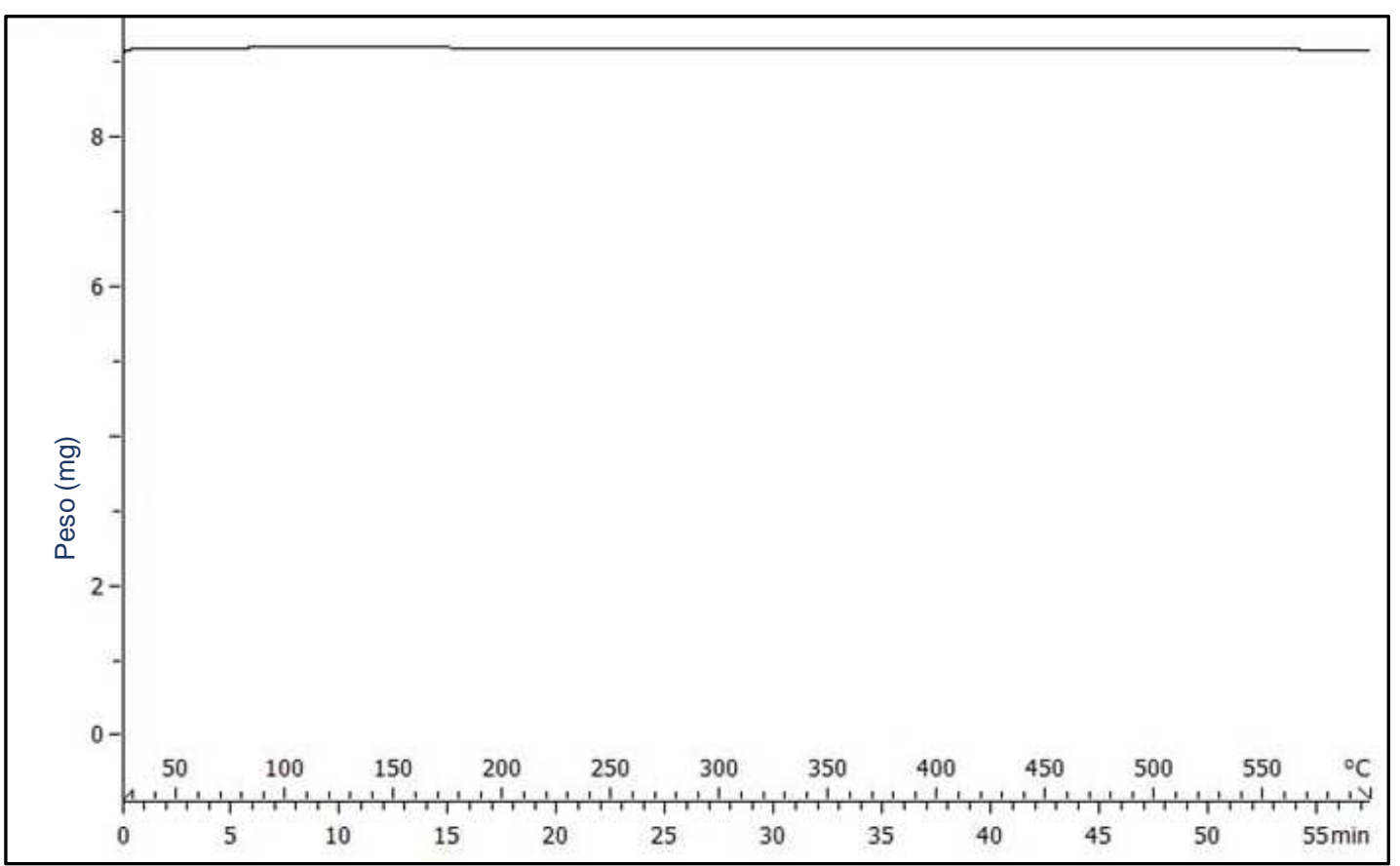

Fonte: Kersting,2019.

\subsubsection{Elemento Filtrante a partir do Tratamento Térmico do Resíduo com Carvão Ativado em Mufla a Gás}


O resíduo também foi processado com carvão ativado usando-se a mufla a gás. A proporção usada para o processamento foi de $10 \mathrm{~g}$ de resíduo para 3,6 $\mathrm{g}$ de carvão ativado. O principal objetivo com este tratamento foi a obtenção de elemento filtrante com o carvão ativado já associado ao resíduo, colaborando para a degradação da fase orgânica original. Com a obtenção deste elemento filtrante seria possível realizar um paralelo direto entre dois tipos de tratamento térmico, via aquecimento normal, e via irradiação de micro-ondas.

Diferente do observado para o tratamento térmico apenas do resíduo em mufla a gás, e do resíduo com carvão ativado irradiados com micro-ondas, o resíduo com carvão ativado tratado na mufla a gás demorou a ocorrer. Enquanto o tratamento térmico total apenas do resíduo levou em torno de 90 minutos, não foi possível constatar o mesmo com o uso de carvão ativado. Isso possivelmente deve-se a temperatura de ignição do carvão ativado ser superior a temperatura de queima da resina epóxi (fase orgânica do resíduo), o que pode trazer dificuldades ao tratamento térmico (ROHDE,2005).

Adicionalmente, a dificuldade de acompanhar visualmente a degradação térmica da fase orgânica do resíduo, que se confundia com a degradação térmica do carvão ativado, fez com que esta opção fosse descartada, após 150 minutos de ensaio. O que pode ser constatado foi que, diferente do tratamento com irradiação de micro-ondas, em que o carvão ativado é um catalisador do processo de degradação da fase orgânica do resíduo, o uso do carvão ativado aumentou a massa da parte da fase orgânica, dificultando o tratamento térmico com mufla a gás.

\subsubsection{Elemento Filtrante a partir do Tratamento Térmico do Resíduo com Carvão Ativado via Irradiação de Micro-ondas}

O processamento do resíduo com carvão ativado via irradiação de microondas foi realizado com o forno 42L, em virtude de problemas de funcionamento com os formos 25L (falha em operação prolongada) e 28L (queimou). As amostras foram processadas na proporção de $10 \mathrm{~g}$ de resíduo para 3,6 g de carvão ativado, para os tempos de 2, 5 e 10 minutos. A quantidade de carvão ativado usada seguiu a proporção de 36\% em massa, de forma a facilitar a verificação do processamento da fase orgânica do resíduo. A proporção foi mantida constante, conforme resultados 
obtidos em ensaios preliminares. O processamento foi dado como completo quando a massa final da mistura resíduo mais carvão ativado ficou igual a $10 \mathrm{~g}$, ou menos.

Nas três condições testadas o processamento foi completo, com massas decrescentes para um maior tempo de processamento. Uma informação que cabe ser colocada é que, como a irradiação induz uma combustão bastante energética, ocorre liberação de fumaça e projeção de uma pequena quantidade de fuligem, o que pode afetar a precisão dos resultados.

Outro fator é que para os tempos de 5 e 10 minutos ocorreu a fusão de partículas de fibra de vidro, resultando em aglomerados com certa de 4 a $5 \mathrm{~mm}$, afetando a regularidade da granulometria do material resultante. Adicionalmente, a quantidade de energia absorvida pelas amostras em alguns casos resultou na quebra do refratário, por excesso de calor.

Na Figura 30 são mostradas as imagens de cadinho refratário com medição de temperatura realizada com termoimagem em infravermelho, e sua condição após um dos ensaios de processamento com irradiação de micro-ondas.

Figura 30 - Termoimagem em infravermelho de cadinho refratário (esquerda), e condição após ensaio de irradiação com micro-ondas por 10 minutos, com resíduo e carvão ativado (proporção de 10/3,6) (direita)

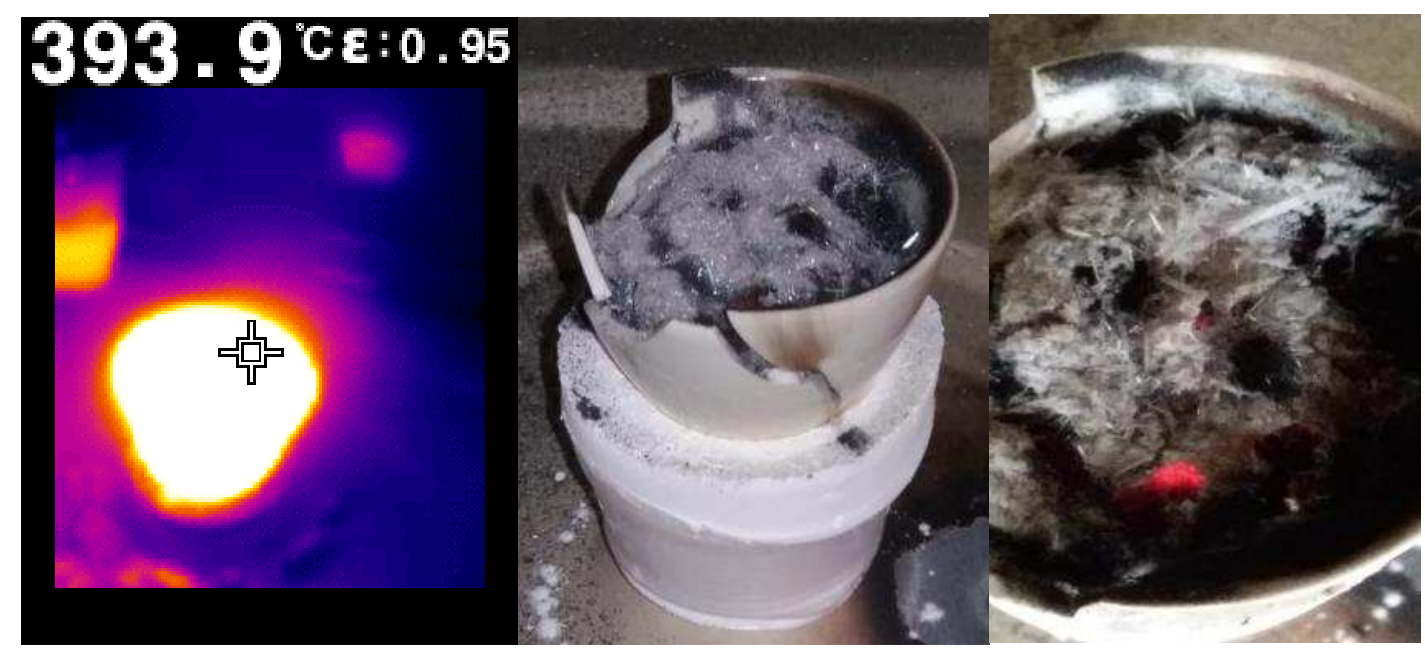

Fonte: Kersting,2019.

Na Figura 30 é possível notar o efeito térmico exercido sobre o próprio material refratário. A medição de temperatura foi realizada no limiar de detecção da câmera térmica, após alguns segundos cessada a irradiação no forno de micro-ondas. É possível notar também o suporte produzido em alumina, para evitar o contato do cadinho com a cavidade do forno, e compensar a altura pela retirada do prato refratário 
e suporte do prato, e observa-se também alguns pontos ainda "ao rubro", apesar de cessado o processamento.

\subsection{Caracterização}

\subsection{Microscopia Ótica}

A avaliação via microscopia ótica permitiu verificar a condição das fibras após o tratamento com carvão ativado e irradiação de micro-ondas realizado. $\mathrm{Na}$ Figura 31, são mostradas as imagens das fibras após o tratamento realizado pelo tempo de 2 minutos de irradiação. Assim como no tratamento térmico via mufla, é possível observar as fibras de vidro associadas em feixes de fibras de tamanhos reduzidos. A principal diferença fica com relação a visualização da extensão do tratamento térmico, em face à presença do carvão ativado. Também é possível observar as fibras de vidro dissociadas, com poucos pontos com resina epóxi mantendo as mesmas reunidas.

Figura 31 - Imagens das fibras após o tratamento realizado pelo tempo de 2 minutos de irradiação obtidas via microscopia ótica: esquerda $5 \mathrm{X}$, direita 10X, de aumento.

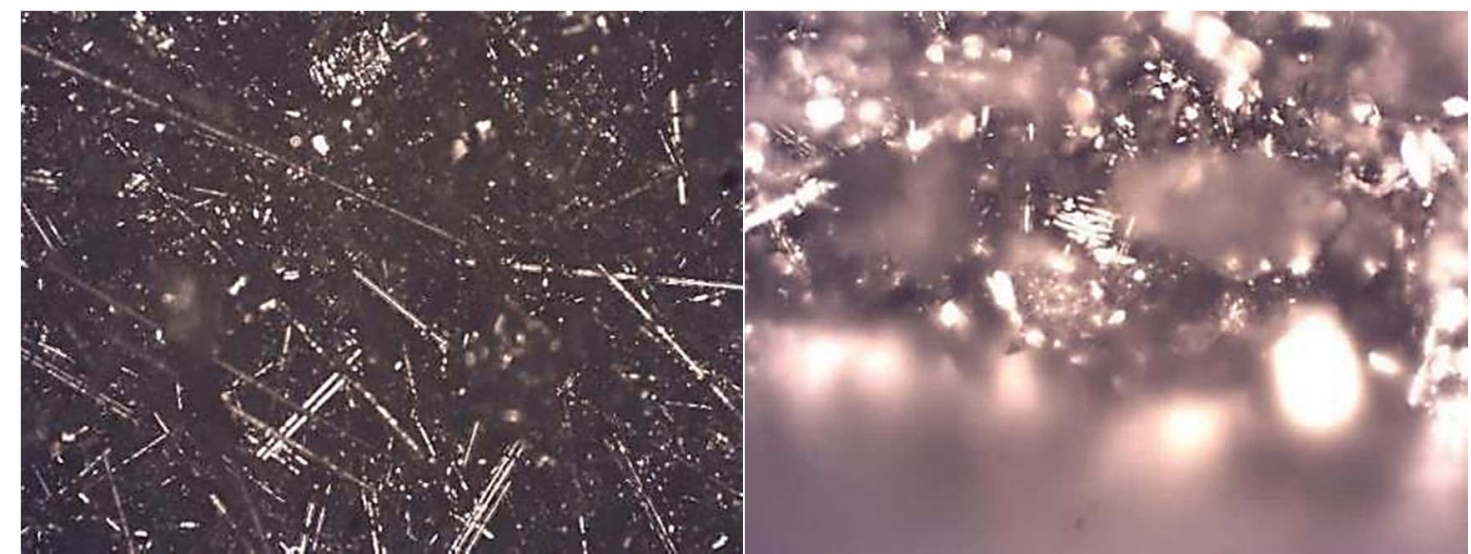

Fonte: Kersting,2019.

$\mathrm{Na}$ Figura 32 são mostradas as imagens das fibras após o tratamento

realizado pelo tempo de 5 minutos de irradiação. É possível notar uma leve melhora, com a visualização das fibras mais dispersas, mas ainda associadas em feixes. 
Figura 32 - Imagens das fibras após o tratamento realizado pelo tempo de 5 minutos de irradiação obtidas via microscopia ótica: no alto a esquerda 5X, no alto a direita 10X, e logo abaixo 20X de aumento

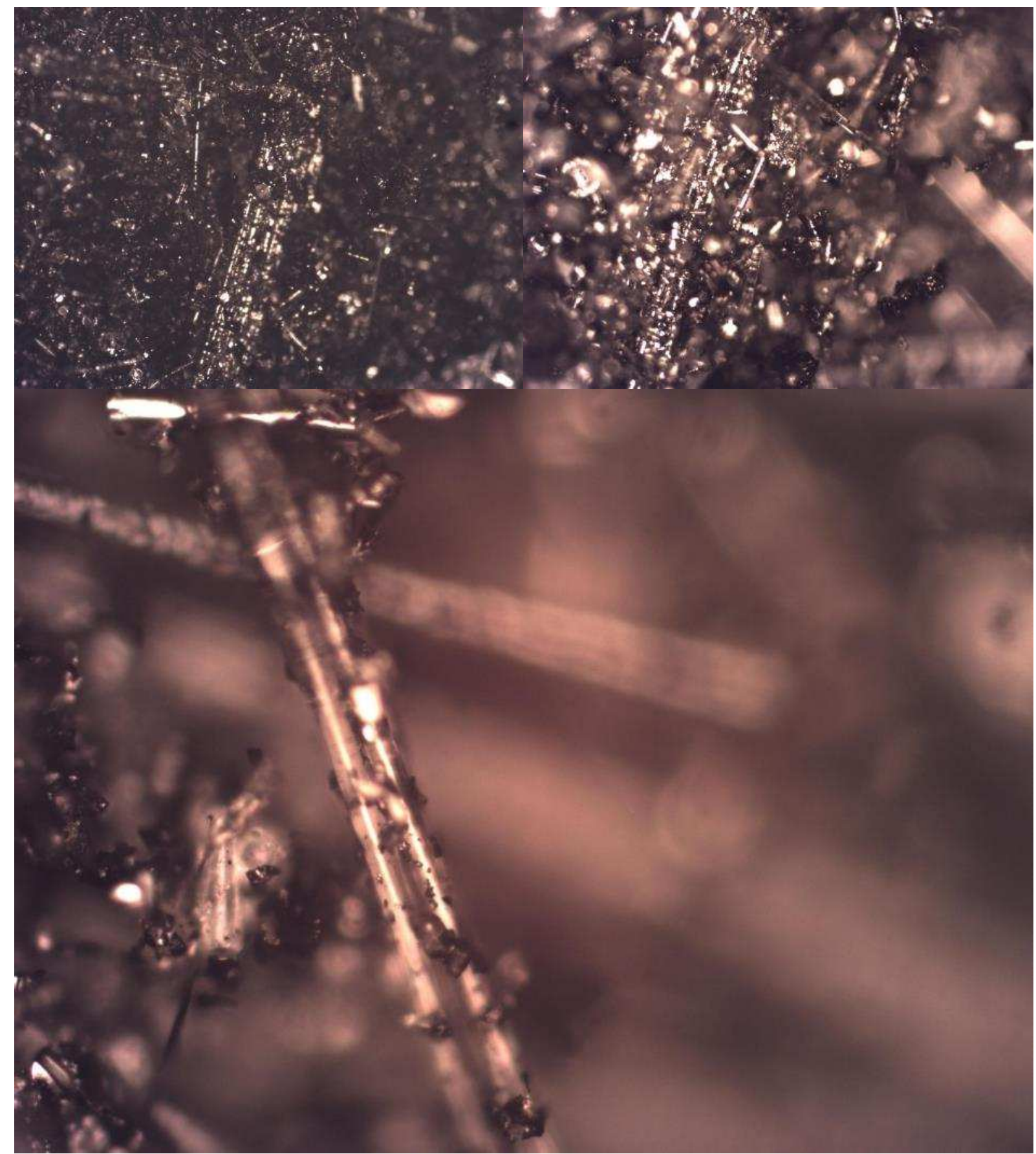

Fonte: Kersting,2019.

Na Figura 33 são mostradas as imagens das fibras após o tratamento realizado pelo tempo de 10 minutos de irradiação. Assim como no caso do tratamento térmico com mufla, as fibras de vidro mostram-se dissociadas, apesar da presença do carvão ativado. 
Figura 33 - Imagens das fibras após o tratamento realizado pelo tempo de 10 minutos de irradiação obtidas via microscopia ótica: a esquerda $5 \mathrm{X}$, a direita 10X, de aumento

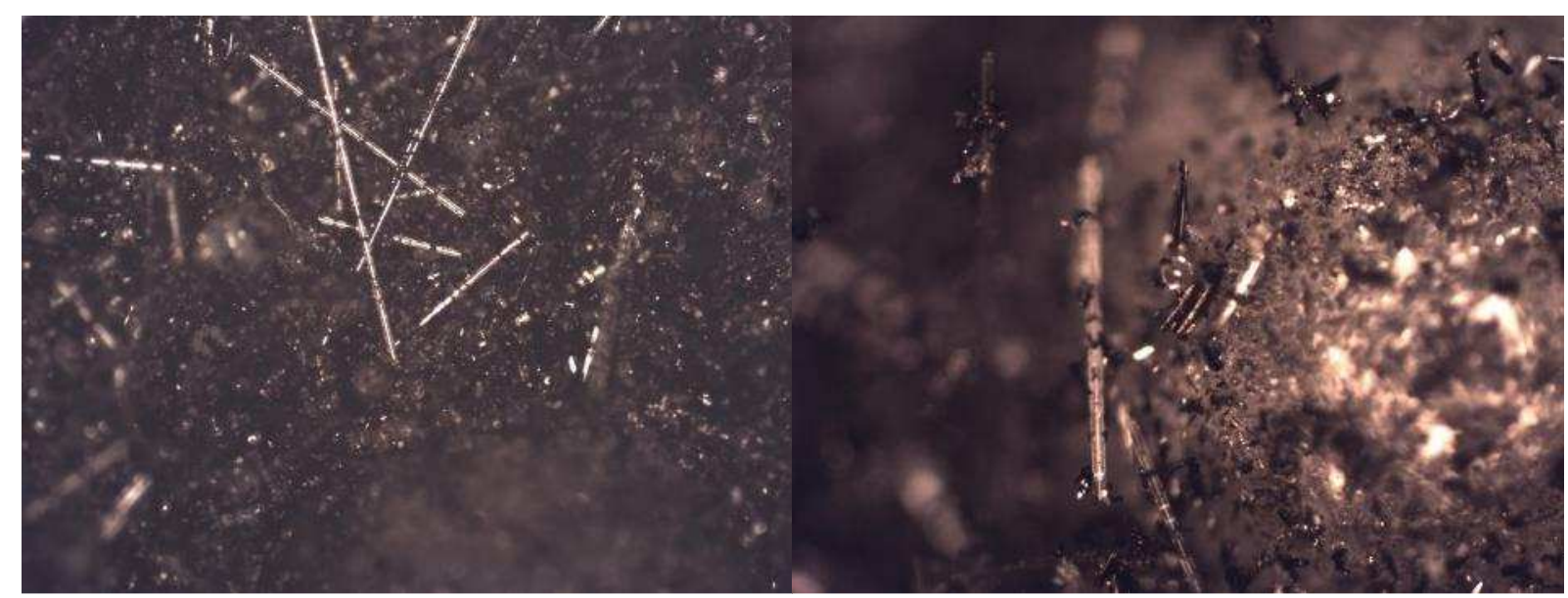

Fonte: Kersting,2019.

Os ensaios a partir de 5 minutos, inclusive, apresentaram uma característica diferenciada. Na Figura 30 foi apresentada a termoimagem de um cadinho que acabou quebrando pelo excesso de calor, a medida de temperatura de aproximadamente $400^{\circ} \mathrm{C}$. Na Figura 34, Figura 35, e Figura 36 são apresentadas imagens onde é possível verificar a fusão das fibras de vidro contidas no resíduo em estudo, o que sugere que foram atingidas temperaturas na ordem de $1400{ }^{\circ} \mathrm{C}$ durante o processamento (ESTADOS UNIDOS DA AMÉRICA,2019). Na Figura 35 é possível notar o início do processo de fusão dos filamentos de fibra de vidro. Diferente das figuras anteriores, onde é possível ver filamentos soltos, os filamentos de fibra se apresentam unidos levemente entre si, formando pequenos aglomerados com partículas de carvão ativado ao redor.

Figura 34- Imagem das fibras após a fusão de filamentos de fibra de vidro para tempo de processamento de 5 minutos: imagens obtidas via microscopia ótica, a esquerda $5 \mathrm{X}$, e a direita 10X, de aumento.

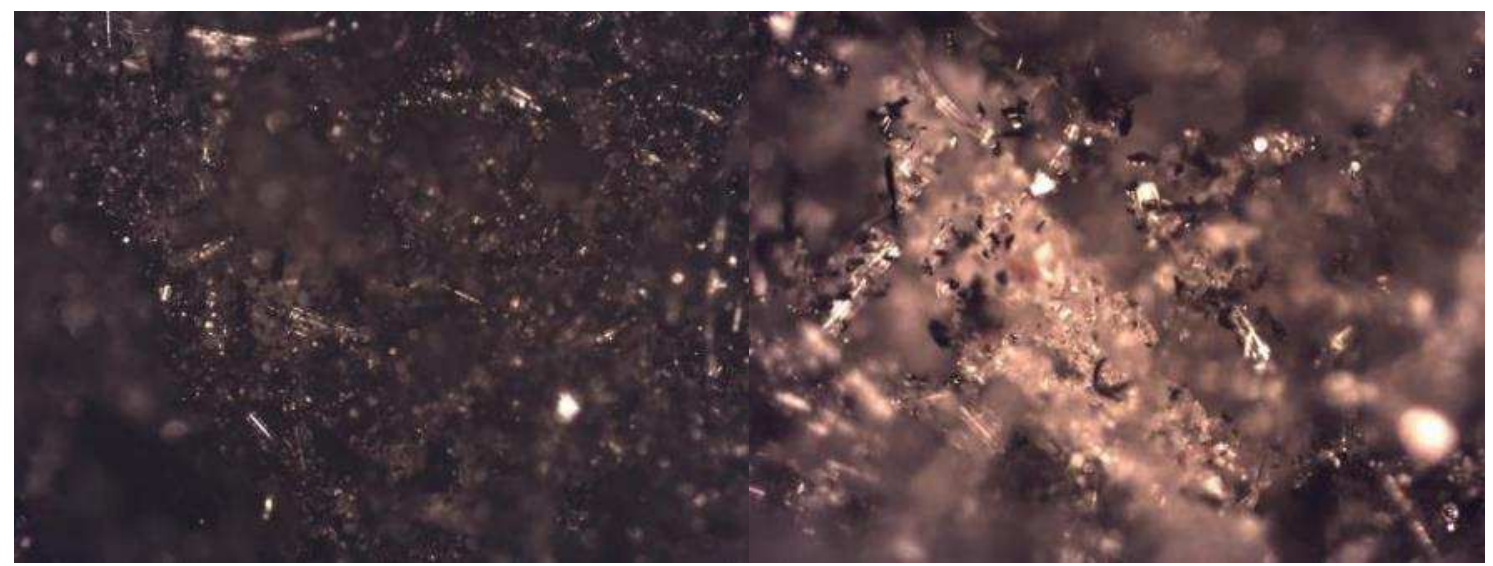

Fonte: Kersting,2019. 
Na Figura 35 é possível notar também o processo de fusão dos filamentos de fibra de vidro. Nesta figura os filamentos de fibra se apresentaram unidos entre si, formando aglomerados com partículas de carvão ativado em seu interior.

Figura 35 - Imagem das fibras após a fusão de filamentos de fibra de vidro para tempo de processamento de 10 minutos: imagens obtidas via microscopia ótica, a esquerda 5X, e a direita 10X, de aumento

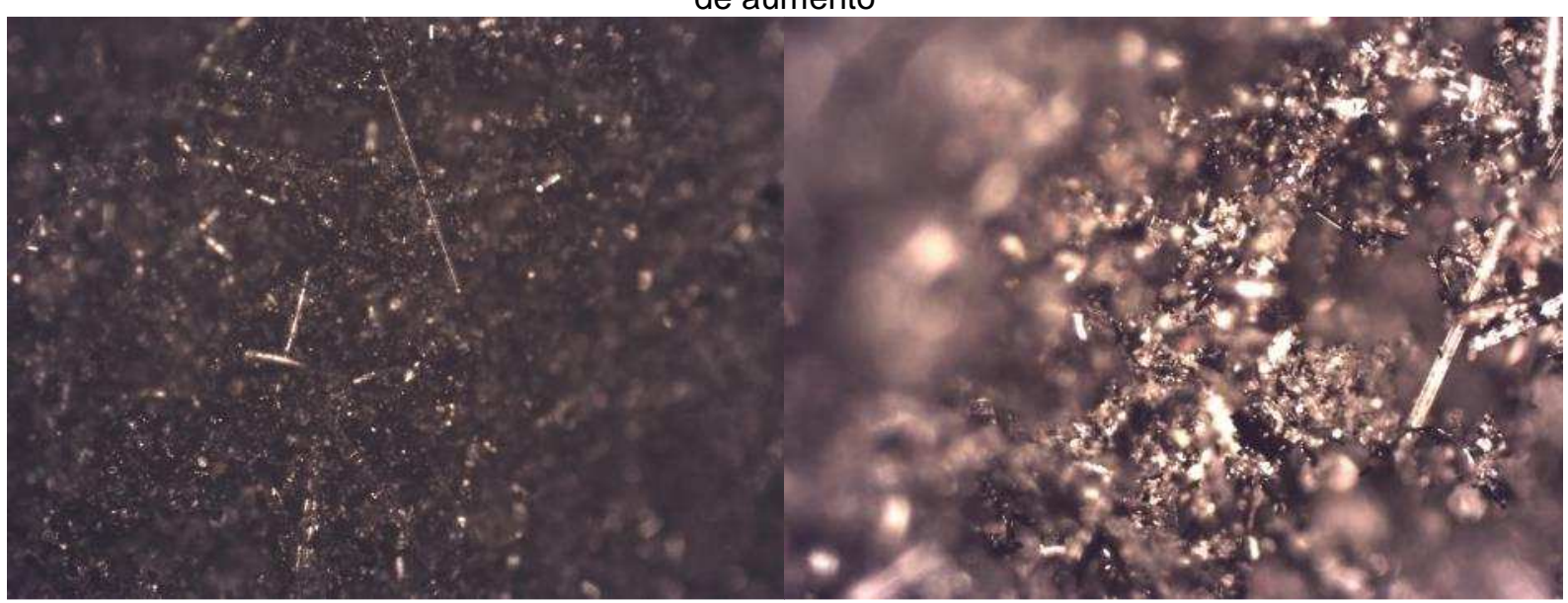

Fonte: Kersting,2019.

Na Figura 36 é possível observar a fusão completa de um conjunto de filamentos de fibra de vidro. Os filamentos de fibra se converteram em apenas um único volume de cor acinzentada, de aspecto vítreo.

Figura 36 - Imagens das fibras após a fusão de filamentos de fibra de vidro para tempo de processamento de 10 minutos obtidas via microscopia ótica: no alto a esquerda $5 \mathrm{X}$, no alto a direita 10X, e logo abaixo a esquerda 20X, e abaixo a direita 50X de aumento.

Fonte: Kersting,2019.

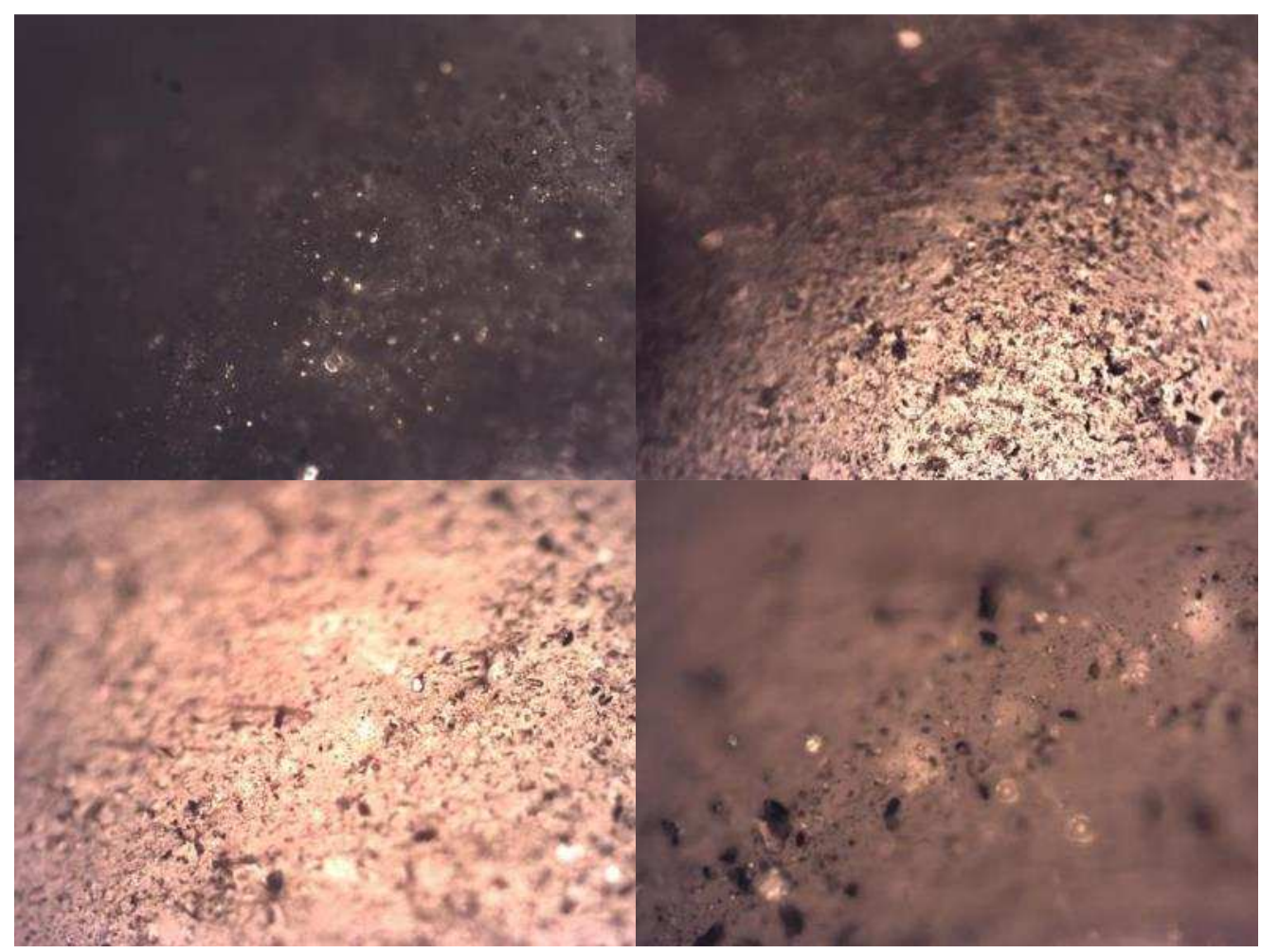




\subsection{Análise Termogravimétrica}

Em complemento a Microscopia Ótica foi realizado ensaio de análise termogravimétrica após o tratamento do resíduo com carvão ativado via irradiação de micro-ondas.

O tratamento térmico do resíduo com carvão ativado via irradiação de micro-ondas foi menos efetivo do que o observado no tratamento realizado em mufla. Na Figura 37 é possível notar uma ligeira perda de massa na ordem de 5\% para uma amostra de resíduo tratado com carvão ativado via irradiação de micro-ondas pelo tempo de 10 minutos.

Figura 37 - Análise termogravimétrica para amostra de resíduo tratada com carvão ativado via irradiação de micro-ondas pelo tempo de 10 minutos.

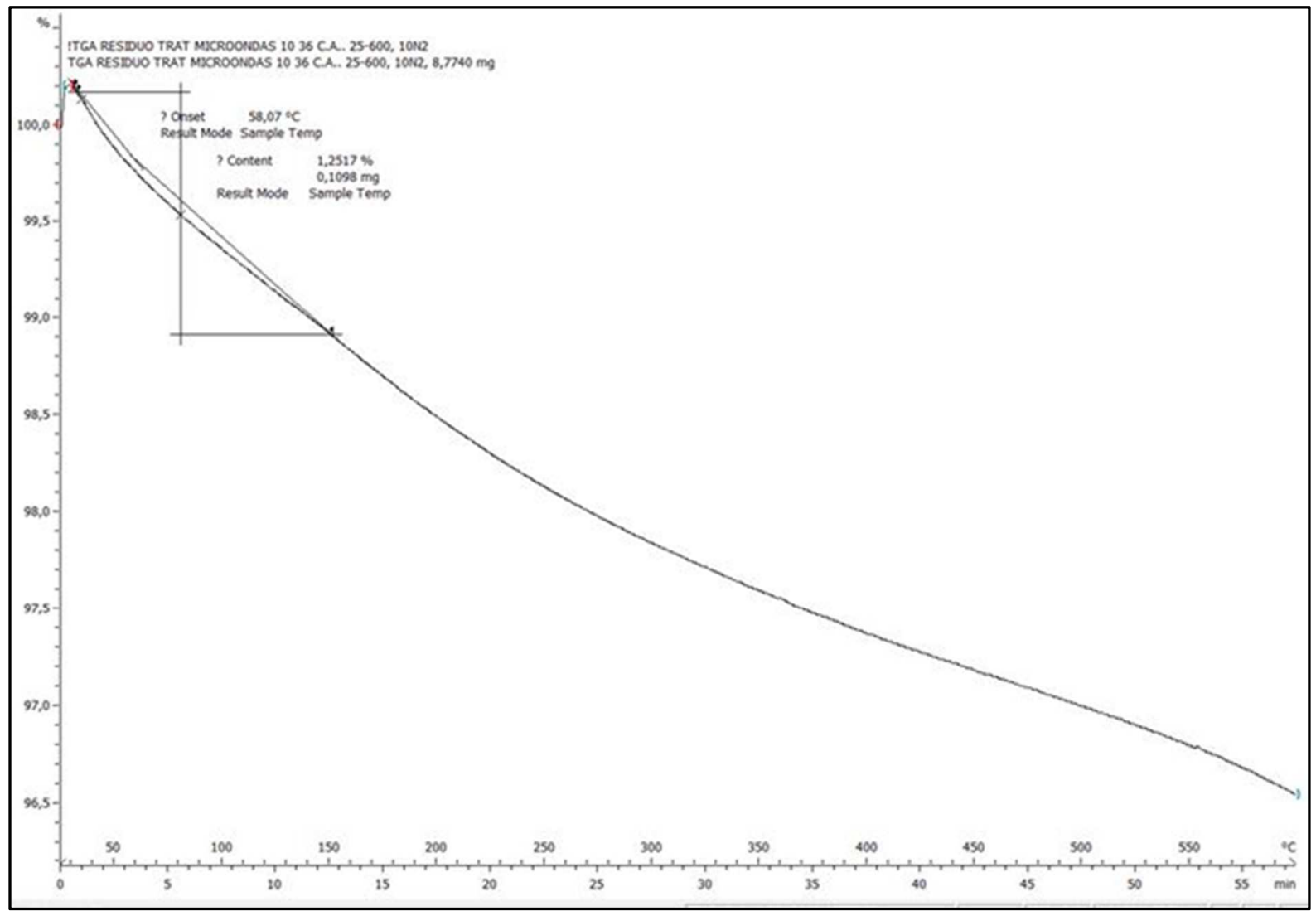

Fonte: Kersting,2019. 
A pequena perda de massa ocorrida indica que o tratamento aplicado realizado (10 minutos, com a adição de $36 \%$ em massa de carvão ativado) retirou toda a massa de material orgânico original, restando apenas a fração de carvão ativado. É esta fração que fica evidenciada após o ensaio de termogravimetria. Cabe ressaltar que o carvão ativado permanece praticamente sem ser retirado em face sua temperatura de degradação ser superior a $450 \stackrel{\circ}{ } \mathrm{C}$ (ROHDE,2005).

\subsubsection{Avaliação Final dos Elementos Filtrantes para Aplicação em Tratamento de Água para Consumo}

Os elementos filtrantes considerados para teste foram os seguintes: resíduo simples (como recebido da Wobben), resíduo tratado em mufla a gás (resíduo sem fase orgânica), resíduo processado com carvão ativado e irradiação de microondas (resíduo sem fase orgânica, aditivado com carvão ativado), carvão ativado, alumina ativada, e zeólita.

As filtrações realizadas seguiram o esquema de filtração apresentado no item 2.5.1., "Filtração". Os testes realizados para avaliação dos elementos filtrantes englobaram as seguintes medições: turbidez, pH, cor, teor de Ferro, dureza total, alcalinidade total, e condutividade. Adicionalmente, também foram avaliados os teores de Alumínio, Arsênico, Bário, Cádmio, Cromo, Cobre, Mercúrio, Manganês, Níquel, Chumbo, Antimônio, Selênio e Zinco, reunidos no item 4.3.2.7., Teor de Contaminantes Inorgânicos.

Os metais acima listados foram reunidos em um mesmo item por serem substâncias inorgânicas que representam risco à saúde, com exceção do Ferro. $O$ teor de Ferro foi estudado a parte por afetar os padrões organolépticos de potabilidade. Dentre as substâncias inorgânicas, apenas teores de cianeto, fluoreto, nitrato, nitrito, e urânio deixaram de ser analisados por restrições dos equipamentos utilizados. As substâncias orgânicas, agrotóxicos, desinfetantes e outros produtos de desinfecção, em face a diversidade e complexidade, também deixaram de ser analisados, ficando reservados para estudos futuros. 


\subsubsection{Turbidez (uT)}

Por ser um requisito legal para potabilidade, a turbidez é usada como parâmetro de avaliação pela empresa local responsável pelo fornecimento de água, e tratamento de esgoto, o SAEE. Um dos pontos de captação do SAEE também é a região por onde passa o rio Ipanema (represa de Ipaneminha), podendo as medidas de turbidez servirem como um referencial de qualidade de água e comparadas com as medições obtidas nos ensaios (SAEE SOROCABA,2019). Na Tabela 11 são apresentados os resultados obtidos para a avaliação de turbidez.

Tabela 11 - Medidas de turbidez para os elementos filtrantes testados.

\begin{tabular}{lc}
\hline \multicolumn{1}{c}{ Elemento Filtrante } & Turbidez (uT) \\
\hline Fornecimento SAAE - Sorocaba * & 0,55 \\
Padrão Exigido Portaria de Consolidação no 5/2017 ** & 0,50 ou 1,00 \\
Sem filtragem - Água Coletada no Rio Ipanema & 17,80 \\
Resíduo Proc. com Carvão Ativado e Micro-ondas (2 minutos) - filtro sanduíche & 0,86 \\
Resíduo Proc. com Carvão Ativado e Micro-ondas (5 minutos) - filtro sanduíche & 2,27 \\
Resíduo Proc. com Carvão Ativado e Micro-ondas (10 minutos) - filtro sanduíche & 2,49 \\
Resíduo Processado com Carvão Ativado e Micro-ondas (2 minutos) - filtro simples & 3,51 \\
Resíduo Original Wobben & 3,67 \\
Resíduo Processado em Mufla & 3,87 \\
Carvão Ativado Puro & 6,43 \\
Zeólita & 6,44 \\
Alumina Ativada Pura & 10,50 \\
\hline
\end{tabular}

* Relatório de Qualidade de Água de Fevereiro de 2019 - SAEE

** Os valores na Portaria de Consolidação variam conforme o tipo de filtração usada no tratamento de água: rápida $(0,5 \mathrm{uT})$ ou lenta (1uT)

Fonte: Kersting,2019.

Como pode ser observado na Tabela 11, os valores para água fornecida pelo SAAE-Sorocaba vêm em linha com os valores exigidos pela Portaria $n^{\circ}$ 5/2017. Com relação aos elementos filtrantes produzidos neste trabalho, destacam-se os resultados obtidos para o resíduo processado com carvão ativado e irradiado com micro-ondas, nas suas diferentes condições de teste. Na Tabela 11 são apresentadas duas variações: tempo de processamento de 2, 5 e 10 minutos; e filtro simples ou sanduíche.

Dentro das diferenças notadas entre os elementos filtrantes com tempo de processamento de 2, 5 e 10 minutos, a principal foi o aparecimento de partículas 
brancas maiores que o observado após o processamento para os tempos de 5 e 10 minutos. O excesso de calor propiciou a fusão de algumas partículas de fibra de vidro, o que fez com que a granulometria original fosse alterada, e sua eficiência reduzida com a formação de partículas maiores, resultando em um elemento filtrante mais heterogêneo. Este fator, por fim, resultou em um filtro de qualidade menor, mas ainda assim melhor que os demais elementos filtrantes testados no que tange aos resultados de turbidez obtidos.

Com relação ao tipo de filtro usado (simples ou sanduíche), o que se pode notar é que a montagem do elemento filtrante com apenas um papel filtro como suporte, sem um outro papel filtro cobrindo o elemento filtrante, fez com que algumas partículas ficassem desagregadas das demais, sobrenadantes, fazendo com que o elemento filtrante ficasse disperso, e com sua eficiência reduzida. A colocação de um segundo papel filtro sobre o elemento filtrante, permitindo que este ficasse mais compactado propiciou que esta situação fosse resolvida, aumentando a eficiência, como se pode notar nos resultados obtidos.

Adicionalmente, destacaram-se com relação aos demais elementos filtrantes os compostos pelo resíduo original Wobben, e pelo resíduo processado em mufla, com resultados melhores que os adsorventes tradicionais carvão ativado, alumina ativada e zeólita. Estes resultados vêm a corroborar suspeitas iniciais com relação ao uso com relativo sucesso dos resíduos processados assim como já ocorre com o uso de areias de granulometria reduzida (CHEREMININOFF,2002).

\subsubsection{2. $\mathrm{pH}$}

Desde a implementação da Portaria oㅡ․ 2.914/2011, do Ministério da Saúde, que serviu como base para a Portaria de Consolidação ํo 5/2017, do mesmo ministério, recomenda que o $\mathrm{pH}$ da água seja mantido na faixa de 6,0 a 9,5 no sistema de distribuição. Esta faixa de valores também é referência para os demais casos de fornecimento de água, inclusive para captação própria. Na Tabela 12 são apresentados os resultados obtidos para valores de $\mathrm{pH}$. 
Tabela 12 - Medidas de $\mathrm{pH}$ para os elementos filtrantes testados

\begin{tabular}{lc}
\hline \multicolumn{1}{c}{ Elemento Filtrante } & pH \\
\hline Padrão Exigido Portaria de Consolidação no 5/2017 & 6,0 a 9,5 \\
Sem filtragem - Água Coletada no Rio Ipanema & 8,1 \\
Resíduo Proc. com Carvão Ativado e Micro-ondas (2 minutos) - filtro sanduíche & 7,6 \\
Resíduo Proc. com Carvão Ativado e Micro-ondas (5 minutos) - filtro sanduíche & 7,6 \\
Resíduo Proc. com Carvão Ativado e Micro-ondas (10 minutos) - filtro sanduíche & 7,6 \\
Resíduo Processado com Carvão Ativado e Micro-ondas (2 minutos) - filtro & 7,4 \\
simples & 7,4 \\
Resíduo Original Wobben & 7,3 \\
Resíduo Processado em Mufla & 8,9 \\
Carvão Ativado Puro & 7,5 \\
Zeólita & 9,8 \\
Alumina Ativada Pura & \\
\hline
\end{tabular}

Fonte: Kersting,2019.

Conforme pode ser observado, nos elementos filtrantes que empregam o resíduo em suas diferentes condições, ocorreu uma redução do $\mathrm{pH}$ para a faixa de 7,5 aproximadamente, inclusive para os casos processados com a adição de carvão ativado e irradiados com micro-ondas. Por outro lado, apenas o elemento filtrante

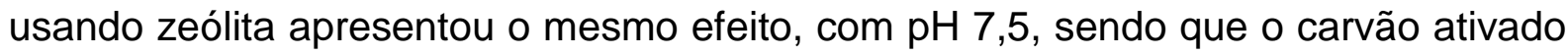
puro elevou o $\mathrm{pH}$ para 8,9, e a alumina ativada pura para $\mathrm{pH} 9,8$.

Para o caso do carvão ativado puro, o efeito no pH depende diretamente do tipo de contaminante que está sendo retirado, e o efeito resultante com a alteração na composição da água. Para o caso da alumina ativada pura, o efeito de elevação do $\mathrm{pH}$ pode ocorrer pela presença de traços de hidróxido de alumínio, resíduo na produção de alumina ativada.

\subsubsection{Cor (uH) e Teor de Ferro (ppm)}

A Portaria de Consolidação oㅡ 5/2017 recomenda que a cor da água destinada para consumo seja mantida com valores inferiores a $15 \mathrm{uH}$. Para teor de ferro, a portaria indica o valor limite de 0,3 ppm. Como o teor de ferro implica indiretamente nos parâmetros de cor da água, ele será apresentado conjuntamente. $\mathrm{Na}$ Tabela 13, são apresentados os resultados obtidos para ambos parâmetros. 
Tabela 13 - Medidas de cor (uH) e teor de ferro (ppm) para os elementos filtrantes testados.

\begin{tabular}{lcc}
\multicolumn{1}{c}{ Elemento Filtrante } & Cor (uH) & Teor de Ferro (ppm) \\
\hline Padrão Exigido Portaria de Consolidação no 5/2017 & 15 & 0,3 \\
Sem filtragem - Água Coletada no Rio Ipanema & 160 & 0,93 \\
$\begin{array}{l}\text { Resíduo Proc. com Carvão Ativado e Micro-ondas (2 minutos) - } \\
\text { filtro sanduíche }\end{array}$ & 50 & 0,57 \\
$\begin{array}{l}\text { Resíduo Proc. com Carvão Ativado e Micro-ondas (5 minutos) - } \\
\text { filtro sanduíche }\end{array}$ & 90 & 0,44 \\
$\begin{array}{l}\text { Resíduo Proc. com Carvão Ativado e Micro-ondas (10 minutos) } \\
\text { - filtro sanduíche }\end{array}$ & 50 & 0,47 \\
$\begin{array}{l}\text { Resíduo Processado com Carvão Ativado e Micro-ondas (2 } \\
\text { minutos) - filtro simples }\end{array}$ & 90 & 0,93 \\
Resíduo Original Wobben & 100 & 0,44 \\
Resíduo Processado em Mufla & 90 & 0,49 \\
Carvão Ativado Puro & 90 & 0,59 \\
Zeólita & 130 & 0,58 \\
Alumina Ativada Pura & 130 & 0,74 \\
\hline
\end{tabular}
Fonte: Kersting,2019.

Todos os elementos filtrantes apresentaram resultados melhorando a cor original da amostra de água sem filtragem, mas sem capacidade para alcançar os parâmetros legais. O melhor resultado obtido foi para o elemento filtrante produzido a partir do resíduo processado com carvão ativado e irradiação de micro-ondas, pelo tempo de 2 minutos, que reduziu a cor a menos de $30 \%$ do valor original (de $160 \mathrm{uH}$, para $50 \mathrm{uH})$.

Com relação ao teor de ferro, todos elementos filtrantes foram insuficientes para a obtenção do parâmetro indicado. Destacam-se os valores obtidos com o uso dos elementos filtrantes produzidos com resíduo processado com carvão ativado e micro-ondas (5 minutos), com uso de filtro sanduíche, com resíduo original Wobben, e resíduo processado em mufla. Os três elementos filtrantes reduziram o teor de ferro em cerca de $50 \%$ do valor original (de 0,93 ppm, para 0,49 e 0,44 ppm).

O elemento filtrante composto de resíduo processado com carvão ativado e irradiação de micro-ondas, pelo tempo de 10 minutos, apresentou comportamento intermediário quando comparado com os demais resíduos processados 2 e 5 minutos. Esta diferença pode dever-se a irregularidades na granulometria do material, que apresentou fusão de parte dos filamentos de fibra de vidro, fato este percebido apenas após o encerramento dos ensaios de filtração, e realização dos ensaios de microscopia ótica. 


\subsubsection{Dureza Total (ppm)}

Para o caso de medição de dureza total, a Portaria de Consolidação no 5/2017 recomenda que os valores para água destinada para consumo sejam inferiores a 500 ppm. Na Tabela 14 seguem os valores medidos para dureza total após filtração com os elementos filtrantes em estudo.

Tabela 14 - Medidas de dureza total (ppm), e \% de redução com o uso dos elementos filtrantes.

\begin{tabular}{lcc}
\multicolumn{1}{c}{ Elemento Filtrante } & Dureza Total (ppm) & \% Redução \\
\hline Padrão Exigido Portaria de Consolidação no 5/2017 & 500 & - \\
Sem filtragem - Água Coletada no Rio Ipanema & 37 & - \\
Resíduo Proc. com Carvão Ativado e Micro-ondas (2 & 25 & $32 \%$ \\
minutos) - filtro sanduíche & 20 & $46 \%$ \\
$\begin{array}{l}\text { Resíduo Proc. com Carvão Ativado e Micro-ondas (5 } \\
\text { minutos) - filtro sanduíche }\end{array}$ & 21 & $43 \%$ \\
Resíduo Proc. com Carvão Ativado e Micro-ondas (10 & & $41 \%$ \\
minutos) - filtro sanduíche & 22 & $38 \%$ \\
Resíduo Processado com Carvão Ativado e Micro- & & $43 \%$ \\
ondas (2 minutos) - filtro simples & 23 & $5 \%$ \\
Resíduo Original Wobben & 21 & $49 \%$ \\
Resíduo Processado em Mufla & 35 & $22 \%$ \\
Carvão Ativado Puro & 19 & 29 \\
Zeólita & & \\
Alumina Ativada Pura & & \\
\hline
\end{tabular}

Fonte: Kerssting,2019.

Todos elementos filtrantes utilizados nos testes apresentaram capacidade de reduzir as medidas de dureza total, com destaque para a zeólita, que reduziu $49 \%$ a dureza total.

Os elementos filtrantes produzidos a partir do resíduo original Wobben também apresentaram bons resultados, com valores de redução da dureza total entre $32 \%$ (resíduo processado com carvão ativado e micro-ondas, por 2 minutos - filtro sanduíche) a $46 \%$ (resíduo processado com carvão ativado e micro-ondas, por 5 minutos - filtro sanduíche).

\subsubsection{Alcalinidade Total (ppm)}

A Portaria no 5/2017 deixa em aberto sobre limites de valores para alcalinidade total. Apesar disso, a alcalinidade total é um fator importante a ser considerado, principalmente para fins de tratamento de água. 
Indiretamente a medida de alcalinidade total dá informações gerais de como está composta a água em análise. A alcalinidade total de uma água é dada pelo somatório das diferentes formas de alcalinidade existentes, ou seja, é a concentração de hidróxidos, carbonatos e bicarbonatos, expressa em termos de carbonato de cálcio. Pode-se dizer que a alcalinidade mede a capacidade da água em neutralizar os ácidos.

As águas superficiais possuem alcalinidade natural em concentração suficiente para reagir com o sulfato de alumínio nos processos de tratamento. Quando a alcalinidade é muito baixa ou inexistente há a necessidade de se provocar uma alcalinidade artificial com aplicação de substâncias alcalinas, tal como cal hidratada ou barrilha (carbonato de sódio) para que o objetivo seja alcançado.

Quando a alcalinidade é muito elevada, procede-se ao contrário, acidificando-se a água até que se obtenha um teor de alcalinidade suficiente para reagir com o sulfato de alumínio ou outro produto utilizado no tratamento da água (BRASIL,2013). Na Tabela 15, são apresentados os valores obtidos para alcalinidade total (ppm) após o uso dos elementos filtrantes.

O valor de alcalinidade total que se destaca dos demais é o para o elemento filtrante composto de alumina ativada pura. Pelo mesmo motivo a presença de traços de hidróxido de alumínio afeta as medições de $\mathrm{pH}$, pode-se verificar o mesmo para medições de alcalinidade total.

Tabela 15 - Medidas de alcalinidade total (ppm) para os elementos filtrantes testados.

\begin{tabular}{lc}
\hline \multicolumn{1}{c}{ Elemento Filtrante } & $\begin{array}{c}\text { Alcalinidade Total } \\
\text { (ppm) }\end{array}$ \\
\hline Sem filtragem - Água Coletada no Rio Ipanema & 39,78 \\
Resíduo Proc. com Carvão Ativado e Micro-ondas (2 minutos) - filtro & 43,76 \\
sanduíche & \\
Resíduo Proc. com Carvão Ativado e Micro-ondas (5 minutos) - filtro & 37,79 \\
sanduíche & 41,77 \\
Resíduo Proc. com Carvão Ativado e Micro-ondas (10 minutos) - filtro & \\
sanduíche & 41,77 \\
Resíduo Processado com Carvão Ativado e Micro-ondas (2 minutos) - filtro & 37,79 \\
simples & 39,78 \\
Resíduo Original Wobben & 63,64 \\
Resíduo Processado em Mufla & 35,80 \\
Carvão Ativado Puro & 429,69 \\
Zeólita & \\
Alumina Ativada Pura &
\end{tabular}

Fonte: Kersting,2019. 


\subsubsection{Condutividade $(\mu \mathrm{S} / \mathrm{cm})$}

Os principais sais que contribuem para a condutividade da água natural são os sais de potássio, sódio, cálcio, magnésio na forma de sulfatos, cloretos, carbonatos e bicarbonatos. Na Tabela 16, são apresentados os valores obtidos para condutividade elétrica para os elementos filtrantes testados neste trabalho.

Tabela 16 - Medidas de condutividade $(\mu \mathrm{S} / \mathrm{cm})$ para os elementos filtrantes testados.

\begin{tabular}{|c|c|}
\hline Elemento Filtrante & $\begin{array}{c}\text { Condutividade } \\
(\mu \mathrm{S} / \mathrm{cm})\end{array}$ \\
\hline Sem filtragem - Água Coletada no Rio Ipanema & 128,7 \\
\hline Resíduo Proc. com Carvão Ativado e Micro-ondas (2 minutos) - filtro sanduíche & 129,8 \\
\hline Resíduo Proc. com Carvão Ativado e Micro-ondas (5 minutos) - filtro sanduíche & 102,9 \\
\hline Resíduo Proc. com Carvão Ativado e Micro-ondas (10 minutos) - filtro sanduíche & 131,6 \\
\hline Resíduo Proc. com Carvão Ativado e Micro-ondas (2 minutos) - filtro simples & 115,3 \\
\hline Resíduo Original Wobben & 108,0 \\
\hline Resíduo Processado em Mufla & 105,9 \\
\hline Carvão Ativado Puro & 168,0 \\
\hline Zeólita & 105,9 \\
\hline Alumina Ativada Pura & 726,3 \\
\hline
\end{tabular}
Fonte: Kersting,2019.

Com exceção do resíduo processado com carvão ativado e micro-ondas (2 minutos - filtro sanduíche), carvão ativado puro e da alumina ativada pura, todos os demais resultados de condutividade obtidos reduziram em algum nível o valor de condutividade original, sugerindo que estes elementos filtrantes tiveram a capacidade de reter íons livres na água coletada.

O resíduo original Wobben, bem como o resíduo processado em mufla, foram os que mais reduziram o valor de condutividade, junto com o resíduo processado com carvão e micro-ondas (5 minutos - filtro sanduíche), com redução na ordem de 20 a $30 \%$ do valor inicial de condutividade.

\subsubsection{Teor de Contaminantes Inorgânicos}

Para fins de medição de contaminantes inorgânicos foram testados os elementos filtrantes produzidos com resíduo tratado em mufla, resíduo tratado com carvão ativado via irradiação de micro-ondas (2 e 5 minutos), resíduo original, e por fim, um elemento filtrante com apenas carvão ativado. 
Os resultados obtidos para a água do rio Ipanema, após análise dos contaminantes inorgânicos, indicaram valores abaixo dos limites quantificáveis do equipamento utilizado (ICP-MS), onde seja, menores que $0,05 \mathrm{mg} / \mathrm{L}$ ou ppm. Para todos os elementos filtrantes testados foram obtidos os mesmos resultados, com exceção dos teores de níquel, antimônio e selênio, que indicaram concentrações de até $0,5 \mathrm{mg} / \mathrm{L}$, superiores aos valores máximos indicados pelo Ministério da Saúde. Este resultado sugere que os elementos filtrantes desenvolvidos sofreram algum tipo de contaminação durante o processamento, sendo os três contaminantes observados na amostra de filtrado obtido após a filtração em elemento filtrante apenas com carvão ativado, e em ensaios adicionais apenas com o resíduo como recebido.

Por outro lado, desconsiderada a possível contaminação nos elementos filtrantes produzidos e testados, é possível afirmar que os elementos filtrantes estão isentos de contaminantes inorgânicos capazes de trazer riscos de consumo. Adicionalmente serão necessários mais testes para avaliar a capacidade de retenção de impurezas, haja visto que a pureza da água do rio Ipanema, antes e após as filtrações, pouco foi afetada. 


\section{CONCLUSÃO}

Neste trabalho foi possível realizar avaliações iniciais com relação ao emprego de resíduos de aparas da fabricação de pás eólicas como elemento filtrante para água. A redução da turbidez, empregando o resíduo como recebido, foi a primeira evidência de que o material tem capacidade para uso como um pré-filtro inicial, em processos de tratamento de água. As análises realizadas dentro dos testes preliminares evidenciaram que o uso de técnicas mais sofisticadas se faz necessário para que a etapa, que envolve o processamento com irradiação de micro-ondas, possa vir a ser suprimida.

Apesar dos desafios implícitos ao tipo de processamento escolhido, desafios estes apenas evidenciados no decorrer dos testes, foi possível obter um elemento filtrante com uma maior confiabilidade do que o uso direto do resíduo como recebido. A calcinação mostrou-se eficiente com o uso de carvão ativado como absorvedor de micro-ondas, alcançando-se mais de $350^{\circ} \mathrm{C}$, para o tempo de exposição de 1 minuto, com $80 \%$ da potência do forno 25L. Com o processamento em micro-ondas por 20 minutos no forno $28 \mathrm{~L}$ foi possível constatar a perda de 19,98\% em peso da amostra, degradando-se a fase orgânica existente no resíduo. A partir dos dados obtidos foi possível prever a necessidade de 46,2 minutos de processamento no forno $28 \mathrm{~L}$ para degradação completa de toda a fase orgânica (36\% de perda de peso). Na avaliação do uso como elemento filtrante, para um tempo de processamento de 20 minutos, foi possível obter um elemento filtrante cujo filtrado apresentou a redução de turbidez (NTU) de 49,35 para 1,94, e um aumento no teor de $\mathrm{O}_{2}$ dissolvido $\left(\% \mathrm{O}_{2}\right)$ de 2,90 para 11,14 .

Visando otimizar o processamento, em face às dificuldades obtidas com o processamento por períodos longos, foram realizados testes com tempos de processamento de até 10 minutos. Para uma concentração de $36 \%$ em peso de carvão ativado, para um tempo de 10 minutos no forno 42L, foi possível obter a fusão da fibra de vidro em pequenos aglomerados, como pode ser visto em microscopia ótica com aumento de 10X. Também para o tempo de 10 minutos de processamento no forno $42 \mathrm{~L}$ foi possível constatar uma perda de peso na ordem de $5 \%$, indicando praticamente a ausência da fase orgânica original. Em face à eficiência obtida, os 
tempos de processamento adotados foram 2, 5 e 10 minutos, sendo estes usados para o processamento e produção dos novos elementos filtrantes.

Por fim, foram realizados ensaios avaliando-se o emprego dos elementos filtrantes obtidos ao longo desta pesquisa com amostras de água encontradas no meio ambiente. No quesito turbidez, o resíduo processado com carvão ativado e microondas, pelo tempo de 2 minutos, com filtro sanduíche, reduziu a turbidez original de 17,80 para 0,86 NTU. Comparativamente, o carvão ativado puro, a zeólita e a alumina ativada pura reduziram apenas para 6,43, 6,44 e 10,50 NTU, respectivamente. No quesito cor da água, o resíduo processado com carvão ativado e micro-ondas, pelo tempo de 2 minutos, com filtro sanduíche, reduziu a cor original de 160 para $50 \mathrm{uH}$. Comparativamente, o carvão ativado puro, a zeólita e a alumina ativada pura reduziram apenas para 90, 130 e $130 \mathrm{uH}$, respectivamente. No quesito teor de ferro, o resíduo processado com carvão ativado e micro-ondas, pelo tempo de 5 minutos, com filtro sanduíche, reduziu o teor de ferro original de 0,93 para 0,44 ppm. Comparativamente, o carvão ativado puro, a zeólita e a alumina ativada pura reduziram apenas para 0,59, 0,78, e 0,74 uH, respectivamente. Para medidas de dureza total, o resíduo processado com carvão ativado e micro-ondas, pelo tempo de 5 minutos, com filtro sanduíche, reduziu os valores originais de 37 para 20 ppm, enquanto para o carvão ativado puro, a zeólita e a alumina ativada pura foram obtidos os valores de 35, 19 e 29 ppm. Para medidas de teor de contaminantes inorgânicos (alumínio, arsênico, bário, cádmio, cromo, cobre, mercúrio, manganês, níquel, chumbo, antimônio, selênio e zinco), em ppm, nenhum dos elementos filtrantes produzidos trouxe um aumento nos valores originais da amostra de água utilizada, ficando todos os teores abaixo do limite de detecção (0,05 ppm).

Os resultados obtidos credenciam a aplicação do resíduo de fibra de vidro/resina epóxi, sem ou com processamento, como um bom elemento filtrante primário, para uso como pré-filtro, reduzindo a turbidez de águas com alto teor de partículas sólidas em suspensão, entre outras características necessárias para o tratamento inicial de águas residuárias.

Cabe reiterar que este trabalho, em virtude da complexidade e da necessidade de técnicas de análise e caracterização mais completas, também se tornou um trabalho exploratório, deixando espaço para o desenvolvimento de mais pesquisas sobre o assunto aqui abordado, como pode ser observado nas "Sugestões para Trabalhos Futuros". 


\section{SUGESTÕES DE TRABALHOS FUTUROS}

Ao final desta pesquisa, ficam sugeridos os seguintes trabalhos futuros, associados de forma complementar ao já realizado:

- Desenvolvimento de análise sistematizada objetivando o emprego de técnicas para caracterização química qualitativa e/ou quantitativa que possam garantir o uso do resíduo como recebido, ou sugerir tratamentos/processamentos simplificados que possam viabilizar o emprego do resíduo para tratamento de água;

- Aprofundar o estudo sobre processamento com irradiação de micro-ondas, principalmente com o uso de carvão ativado como absorvedor de irradiação e posterior absorvedor químico, com emprego de técnicas para caracterização química qualitativa e/ou quantitativa que possam garantir o uso para elementos filtrantes;

- Estudar a possibilidade de processar os elementos filtrantes a base de resíduo de fibra de vidro e carvão ativado usados via reciclagem térmica, de forma a reconstituir o elemento filtrante, e gerar energia com a combustão do que foi absorvido no elemento filtrante; $\mathrm{e}$

- Caracterizar os filtrados obtidos pelo emprego dos elementos filtrantes criados com o resíduo, bem como com suas variações tratadas/processadas quimicamente, por meio de técnicas para detecção dos íons presentes, assim como os produtos orgânicos presentes, tendo como referência a Portaria de Consolidação nº 5/2017, do Ministério da Saúde.

Considerando outros empregos do resíduo de aparas de pás eólicas, diferentes dos estudados nesta pesquisa, ficam como sugestão para trabalhos futuros:

- Aplicação do resíduo em substituição a fibra de vidro em pó em produtos industriais que já utilizam a mesma em suas composições, como peças automobilísticas, por exemplo; e

- Avaliar o emprego do resíduo em isolantes térmicos para aplicações especiais, dada a sua compatibilidade química com resinas termofixas pela presença de traços de resina epóxi na composição original do resíduo. 


\section{REFERÊNCIAS BIBLIOGRÁFICAS}

ABNT - Associação Brasileira De Normas Técnicas. NBR10004: classificação dos resíduos sólidos quanto aos seus potenciais ao meio ambiente e à saúde pública, para que possam ser gerenciados adequadamente. Rio de Janeiro. 2004.

ALMACO. Compolife. Disponível em: <http://almaco.org.br/programa-almacode-logistica-reversa/>. Acesso em: 21 de mar. de 2019.

ASHBY, M. F. Engenharia ambiental: conceitos, tecnologia e gestão. Editora Elsevier. Rio de Janeiro. 2013.

BAI. Y. et al. Chemical recycling of carbon fibre reinforced epoxy resin composites in oxygen in supercritical water. Materials \& Design, v. 31, n. 2, p. 999-1002, 2010.

BAJPAI, PRATIMA. Update on Carbon Fiber. Shawbury, Reino Unido, 2013.

BARBOZA, A. C. R. N. Aquecimento em forno micro-ondas: alguns conceitos fundamentais. Química Nova, v. 24, n. 6, p. 901-904, 2001.

BRANDUP, J. Recycling and Recovery of Plastics. Hanser Verlag, 1996.

BRASIL. Resolução nํ 357/2005 - CONAMA, de 17 de Março de 2005. Dispõe sobre a classificação dos corpos de água e diretrizes ambientais para o seu enquadramento, bem como estabelece as condições e padrões de lançamento de efluentes, e dá outras providências. Disponível em: $<$ https://cetesb.sp.gov.br/aguas-interiores/wp-

content/uploads/sites/12/2013/11/res-357-17032005.pdf>. Acesso em: 25 de mar. de 2019.

BRASIL. Lei no 12.305, de 02 de agosto de 2010. Institui a Política Nacional de Resíduos Sólidos; altera a Lei no 9.605, de 12 de fevereiro de 1998; e dá outras providências. Disponível em: <http://www.planalto.gov.br/ccivil 03/ Ato20072010/2010/Lei/L12305.htm>. Acesso em: 21 de jul. 2019.

BRASIL. Manual prático de análise de água / Fundação Nacional de Saúde Ministério da Saúde. Brasília. 2013. Disponível em: $<$ http://www.funasa.gov.br/site/wp-

content/files $\mathrm{mf} / \mathrm{manual}$ pratico de analise de agua 2.pdf>. Acesso em: 23 de jul. de 2019.

BRASIL. Portaria de Consolidação no 5 - 03 de outubro de 2017. Consolidação das normas sobre as ações e os serviços de saúde do Sistema Único de Saúde. Disponível em: <http://www.agricultura.gov.br/assuntos/inspecao/produtosvegetal/legislacao-1/biblioteca-de-normas-vinhos-e-bebidas/portaria-deconsolidacao-no-5-de-3-de-outubro-de-2017.pdf/view >. Acesso em: 22 de mar. 
de 2019.

BRASIL. Resolução nำ 583, Conselho Nacional de Saúde. Disponível em: <http://conselho.saude.gov.br/resolucoes/2018/Reso583.pdf>. Acesso em: 22 de mar. de 2019.

CALLISTER JR., W. D. Fundaments of Materials Science and Engineering. John Willey and Sons, EUA, 2001.

CHEREMISINOFF, N. P. Handbook of Water and Waste-water Treatment Technologies. Buttlerworth-Heinemann Publishers. Europa. 2002.

CLARK, D.E. et al. Processing materials with microwave energy. Materials Science and Engineering, v. A287, p. 153-158, 2000.

CORBUCCI NETO, Mario. Política Nacional de Resíduos Sólidos e a Responsabilidade Compartilhada. Revista Meio Ambiente Industrial. São Paulo, 12 de abril de 2012.

DAIMLERCHRYSLER. Fritz Dannenhauer. Process for Recycling Composite Materials. US6537341B2, 30 de maio de 2000 a 23 de julho de 2019.

DASKALOPOULOS, E., BADR, O., PROBERT, S. D. Economic and Environmental Evaluations of Waste Treatment and Disposal Technologies for Municipal Solid Waste. Applied Energy, v. 58, n. 4, p. 209-255, 1997.

DEVOLVA. Sistema Devolva. Disponível em: <http://www.devolva.com.br/adevolva/historia/>. Acesso em: 21 de mar. de 2019.

ELHAJJAR, R. Composite Structures: Effects of Defects. Wiley. Inglaterra. 2019.

ESTADOS UNIDOS DA AMÉRICA. Law and Regulations - U.S. E.P.A. Disponível em: <http://www.epa.gov/lawsregs>. Acesso em: 09 de nov. de 2012.

ESTADOS UNIDOS DA AMÉRICA. Fiber Glass Manufacturing. Disponível em: $<$ https://www3.epa.gov/ttnchie1/ap42/ch11/final/c11s13.pdf>. Acesso em: 03 de abr. de 2019.

EURECICLO. Blog Eureciclo. Disponível em: $<$ https://blog.eureciclo.com.br/2018/09/tudo-o-que-voce-precisa-saber-sobrepolitica-nacional-de-residuos-solidos-pnrs/>. Acesso em: 21 de mar. de 2019.

FIBERLINE. Breakthrough: Recycling of fibreglass is now a reality - Fiberline Composites.

Disponível em: $<$ http://www.fiberline.com/news/miljoe/breakthrough-recycling-fibreglass-nowreality $>$. Acesso em: 21 de mar. de 2019.

FORTUNY, M. Principais aplicações das micro-ondas na produção e refino de petróleo. Quimica Nova, v. 31, n. 6, p.1553-1561, 2008. 
FOUST, A. Princípios das Operações Unitárias. 2ª Edição. Editora LTC. Rio de Janeiro. 1982.

GOODSHIP, V. Introduction to Plastics Recycling. Smiters Rapra, 2007, Grã-Bretanha.

GOSAU, J. M. et al. Modular Recycling Systems for Isolated Waste Producers. Proceedings SAMPE 2010 Symposium and Exhibition, 2010.

GUIA de potabilidade para substâncias químicas; Gisela de Aragão Umbuzeiro (coord.) - São Paulo : Editora Limiar, OUT2012.

HALIWELL, S. End of Life of Composite Waste: Recycle, Reuse or Dispose. National. Composites Network Best Practice Guide. Netcomposites. 2006.

HAYES, B. L. Microwave synthesis: chemistry at the speed of light. Matthews: CEM, 2003.

ILSI. International Life Sciences Institute. Controle de Substâncias Químicas em Água Potável: Valores Máximos Permitidos (VMP). Disponível em: $<$ http://ilsibrasil.org/wp-content/uploads/sites/9/2018/08/Dr.-Fabio-KummrowFood safety 2018 FKummrow.pdf >. Acesso em: 22 de mar. de 2019.

IUS NATURA. Portaria 5/2017 - Padrões de potabilidade da água para consumo humano. Disponível em: <https://iusnatura.com.br/potabilidade-daagua/ >. Acesso em: 22 de mar. de 2019.

JIANG, G. Z. et al. Characterization of carbon fibre/epoxy resin composites using supercritical n-propanol. Composites Science and Technology, v, 69, p.192-198, 2009.

KAPPE, C. O.; DALLINGER, D.; MURPHREE, S. S. Pratical microwave synthesis for organic chemistry: strategies, instruments, and protocols. Weinheim: Wiley-VCH Verlag, 2009.

KERSTING, D. F. Cura de compósitos de sistemas epóxi via irradiação de micro-ondas. Dissertação (Mestrado) - Escola Politécnica da USP, São Paulo, 2014.

KERSTING, D. F. Reciclagem de aparas de pás eólicas para a produção de elementos filtrantes para tratamento de água. Tese (Doutorado) - Escola Politécnica da USP, São Paulo, 2019.

KIRAN, E., BRENNECKE, J. F. Supercritical Fluid Engineering Science: Fundamentals and Applications, Oxford Science Publications, 2001.

KNOX, C. E. Fiberglass Reinforcement. In. Lubin, G. Van Nostrand Reinhold Company. EUA. 1982.

KOK, L.P. et al. Programming the microwave oven. Journal of Neuroscience Methods, v. 55, p. 119-124, 1994. 
$\mathrm{KU}, \mathrm{H} . \mathrm{S}$. et al. Productivity improvement through the use of industrial microwave technologies. Computers \& Industrial Engineering, v. 42, p.281-290, 2002.

LESTER, E. et al. Microwave heating as a means for carbon fibre recovery from polymer composites: a technical feasibility study. Materials Research Bulletin, v. 39, p.1549-1556, 2004.

LIBÂNIO, M. Fundamentos de Qualidade e Tratamento de Água. Editora Átomo. Campinas, Brasil. 2010.

LIU, Y. et al. Recycling of carbon fibre reinforced composites using water in subcritical conditions. Materials Science \& Engineering A: Structural Materials: Properties, Microstructure and Processing, v. 520, n.1-2, p.179183, 2009.

LUZ, A. B. Zeólitas: propriedades e usos industriais. CETEM/CNPq. Rio de Janeiro. 1995.

MANRICH, S. Identificação de Polímeros: Uma Ferramenta para a Reciclagem. EDUFSCAR, São Carlos, 1997.

MCABE, W. L. Operaciones Unitarias en Ingeniería Química. 7ª Edição. Editora McGraw-Hill. Cidade do México. 2007.

MORIN, C. et al. Near and supercritical solvolysis of carbon fibre reinforced polymers (CFRPs) for recycling carbon fibers as a valuable resource: State of the art. Journal of Supercritical Fluids, v. 66, p. 232-240, 2012.

MURPHY, J. The Reinforced Plastics Handbook. 2nd.Ed. Elsevier Advanced Tecnology. Oxford. Inglaterra. 1998.

NPPG. Reforço Estrutural Em Fibra De Carbono Para Estruturas De Concreto Armado. Disponível em <http://www.nppg.org.br/patorreb/files/artigos/80533.pdf>. Acesso em $21 \mathrm{de}$ março de 2019.

NUNES, D. Temas Ambientais ganham destaque nesta quarta-feira. Jornal $\mathbf{O}$ Sul. Porto Alegre, 10 de abril de 2012.

ODIAN, G. G. Principles of Polymerization. 3rd. Ed. John Wiley. Nova York, EUA, 1991.

OKAJIMA, I. et al. Decomposition of epoxy resin and recycling of CFRP with sub- and supercritical water, Kagaku Kogaku Ronbunshu, v. 28, n. 5, p. 553558, 2002.

PECORARO, E. et al. Adaptações em forno de micro-ondas doméstico para utilização em laboratório. Química Nova, v. 20, n. 1, p. 89-92, 1997.

PICKERING, S. J. Recycling technologies for thermoset composite materials current status. Composites: Part A, v.37, p.1206-1215, 2006. 
PICKLES, C. A. Microwave heating behaviour of nickeliferous limonitic laterite ores. Minerals Engineering, v. 17, p.775-784, 2004.

PINERO-HERNANZ, R. et al. Chemical recycling of carbon fibre composites using alcohols under subcritical and supercritical conditions. Journal of Supercritical Fluids, v. 46, n. 1, p. 83-92, 2008.

PINERO-HERNANZ, R. et al. Chemical recycling of carbon fibre reinforced composites in nearcritical and supercritical water, Composites Part A: Applied Science and Manufacturing, v. 39, n.3, p.454-461, 2008.

PORTAL ECOEFICIENTES. Taipa de Mão ou Pau a Pique. Disponível em $<$ http://www.ecoeficientes.com.br/taipa-de-mao-ou-pau-a-pique/>. Acesso em 21 de março de 2019.

ROHDE, G.M. Evidências Científicas da Impossibilidade da Combustão Espontânea do Carvão Vegetal Produzido no Estado do Rio Grande do Sul. CIENTEC. Porto Alegre, Brasil. 2005.

ROLIM, A. M. A Reciclagem de Resíduos Plásticos Pós-consumo em Oito Empresas do Rio Grande do Sul. Dissertação (Mestrado Em Administração) -PPGA/UFRGS, Porto Alegre, 2000.

ROUQUEROL, F. Adsorption by Powders and Porous Solids: Principles, Methodology and Applications. Academic Press. 1999.

SADICOFF, B. L.; AMORIM, M. C. V.; MATTOS, M. C. S. Uma demonstração simples e visual do efeito do aquecimento com micro-ondas em reações de polimerização. Química Nova, v. 23, n. 4, p. 557-559, 2000.

SAEE SOROCABA. Qualidade de Água - SAEE Sorocaba. Disponível em: $<$ http://www.saaesorocaba.com.br/qualidade-da-agua/>. Acesso em: 25 de mar. de 2019.

SANSEVERINO, A. M. Micro-ondas em síntese orgânica. Química Nova, v. 25, n. 4, p. 660-667, 2002.

SÃO PAULO Enquadramento dos Corpos de Água. Disponível em: $<$ http://www.sigrh.sp.gov.br/enquadramentodoscorposdagua >. Acesso em: 03 de abr. de 2019.

SÃO PAULO. Mapa Diagnóstico da Bacia Hidrográfica do Rio Sorocaba e Médio-Tietê. Unidade de Gerenciamento de Recursos Hídricos 10 (UGRHI-10). Disponível em: $<$ http://www.sigrh.sp.gov.br/public/uploads/documents/7099/mapadiagnostico. pdf>. Acesso em: 25 de mar. de 2019.

STARR, T. F. Pultrusion for Engineers. CRC Press. Cambrigde. Inglaterra. 2000.

STESSEL, R. I. Recycling and Resource Recovery Engineering: Principles of Waste Processing. New York, Springer, 1996. 
STEVENS, M. P. Polymer Chemistry an Introduction. 3rd. Ed. Oxford University Press. Nova York. EUA. 1999.

TANRATTANAKUL, V. et al. Comparison of Microwave and Thermal Cure of Epoxy-Anhydride Resins Mechanical Properties and Dynamic Characteristics. Journal of Applied Polymer Science, v. 97, p. 1442-1461, 2005.

THOSTENSON, E.T., CHOU, T.-W. Microwave processing: fundamentals and applications. Composites: Part A, v. 30, p. 1055-1071, 1999.

TORRES, A., et al. Recycling by pyrolysis of thermoset composites: characteristics of the liquid and gaseous fuels obtained. Fuel, v.79, p.897-902, 2009.

TRADING ECONOMICS. Brasil Taxa de Crescimento do PIB. Disponível em: $<$ https://pt.tradingeconomics.com/brazil/gdp-growth>. Acesso em: 24 mar. de 2019.

UNIÃO EUROPÉIA. Directive 2000/53/EC. Disponível em: <https://eurlex.europa.eu/LexUriServ/LexUriServ.do?uri=CONSLEG:2000L0053:2005070 1:EN:PDF>. Acesso em: 23 de jul. de 2019.

VERDE GHAIA. Potabilidade da água: Breve Introdução. Disponível em: $<$ https://www.verdeghaia.com.br/blog/potabilidade-da-agua-breveintroducao/ >. Acesso em: 22 de mar. de 2019.

WARRING, R. H. The Glassfiber Handbook. Special Interest Model Books. Norfolk. Inglaterra, 2008.

WIEBECK, H., PIVA, A. M. Reciclagem do Plástico: Como fazer da Reciclagem um Negócio Lucrativo. Editora ArtLiber, 2004.

YANG, Y. et al. Recycling of Composite Materials. Chemical Engineering and Processing. v. 51, p. 53-68, 2012.

ZHANG, W et al; Improving interfacial and mechanical properties of carbon nanotube-sized carbon fiber/epoxy composites, Carbon, v. 145, p. 629-639, 2019. 


\section{ANEXO 1}

Tabela 17 - Anexo 2 do Anexo XX: tabela de padrão de turbidez para água pós-filtração ou prédesinfecção (origem: Portaria MS/GM № 2.914/2011, Anexo 2)

\begin{tabular}{cc}
\hline Tratamento da água & VMP(1) \\
\hline Desinfecção (para águas subterrâneas) & $1,0 \mathrm{uT}(2)$ em 95\% das amostras \\
Filtração rápida (tratamento completo ou & $0,5(3) \mathrm{uT}(2)$ em 95\% das amostras \\
filtração direta) & \\
Filtração lenta & $1,0(3) \mathrm{UT}(2)$ em 95\% das amostras \\
\hline
\end{tabular}

Notas:

(1) Valor Máximo Permitido.

(2) Unidade de Turbidez.

(3) Este valor deve atender ao padrão de turbidez de acordo com o especificado no $\S 2^{\circ}$ do art. 30 . 


\section{ANEXO 2}

Tabela 18 - Anexo 7 do Anexo XX: tabela de padrão de potabilidade para substâncias químicas que representam risco à saúde (origem: Portaria MS/GM no 2.914/2011, Anexo 7)

\begin{tabular}{|c|c|c|c|}
\hline Parâmetro & CAS(1) & Unidade & VMP(2) \\
\hline \multicolumn{4}{|c|}{ INORGÂNICAS } \\
\hline Antimônio & $7440-36-0$ & $\mathrm{mg} / \mathrm{L}$ & 0,005 \\
\hline Arsênio & $7440-38-2$ & $\mathrm{mg} / \mathrm{L}$ & 0,01 \\
\hline Bário & $7440-39-3$ & $\mathrm{mg} / \mathrm{L}$ & 0,7 \\
\hline Cádmio & $7440-43-9$ & $\mathrm{mg} / \mathrm{L}$ & 0,005 \\
\hline Chumbo & $7439-92-1$ & $\mathrm{mg} / \mathrm{L}$ & 0,01 \\
\hline Cianeto & $57-12-5$ & $\mathrm{mg} / \mathrm{L}$ & 0,07 \\
\hline Cobre & $7440-50-8$ & $\mathrm{mg} / \mathrm{L}$ & 2 \\
\hline Cromo & $7440-47-3$ & $\mathrm{mg} / \mathrm{L}$ & 0,05 \\
\hline Fluoreto & $7782-41-4$ & $\mathrm{mg} / \mathrm{L}$ & 1,5 \\
\hline Mercúrio & $7439-97-6$ & $\mathrm{mg} / \mathrm{L}$ & 0,001 \\
\hline Níquel & $7440-02-0$ & $\mathrm{mg} / \mathrm{L}$ & 0,07 \\
\hline Nitrato (como N) & $14797-55-8$ & $\mathrm{mg} / \mathrm{L}$ & 10 \\
\hline Nitrito (como N) & $14797-65-0$ & $\mathrm{mg} / \mathrm{L}$ & 1 \\
\hline Selênio & $7782-49-2$ & $\mathrm{mg} / \mathrm{L}$ & 0,01 \\
\hline Urânio & $7440-61-1$ & $\mathrm{mg} / \mathrm{L}$ & 0,03 \\
\hline \multicolumn{4}{|c|}{ ORGÂNICAS } \\
\hline Acrilamida & $79-06-1$ & $\mu g / L$ & 0,5 \\
\hline Benzeno & $71-43-2$ & $\mu g / L$ & 5 \\
\hline Benzo[a]pireno & $50-32-8$ & $\mu \mathrm{g} / \mathrm{L}$ & 0,7 \\
\hline Cloreto de Vinila & $75-01-4$ & $\mu g / L$ & 2 \\
\hline 1,2 Dicloroetano & $107-06-2$ & $\mu g / L$ & 10 \\
\hline 1,1 Dicloroeteno & $75-35-4$ & $\mu \mathrm{g} / \mathrm{L}$ & 30 \\
\hline \multirow[t]{2}{*}{1,2 Dicloroeteno (cis + trans) } & 156-59-2 (cis) & \multirow[t]{2}{*}{$\mu \mathrm{g} / \mathrm{L}$} & \multirow{2}{*}{50} \\
\hline & $156-60-5$ (trans) & & \\
\hline Diclorometano & $75-09-2$ & $\mu \mathrm{g} / \mathrm{L}$ & 20 \\
\hline Di(2-etilhexil) ftalato & $117-81-7$ & $\mu \mathrm{g} / \mathrm{L}$ & 8 \\
\hline Estireno & $100-42-5$ & $\mu \mathrm{g} / \mathrm{L}$ & 20 \\
\hline Pentaclorofenol & $87-86-5$ & $\mu \mathrm{g} / \mathrm{L}$ & 9 \\
\hline Tetracloreto de Carbono & $56-23-5$ & $\mu \mathrm{g} / \mathrm{L}$ & 4 \\
\hline Tetracloroeteno & $127-18-4$ & $\mu g / L$ & 40 \\
\hline \multirow{3}{*}{ Triclorobenzenos } & 1,2,4-TCB (120-82-1) & \multirow{3}{*}{$\mu \mathrm{g} / \mathrm{L}$} & \multirow[t]{3}{*}{20} \\
\hline & $1,3,5-\mathrm{TCB}(108-70-3)$ & & \\
\hline & $1,2,3-\mathrm{TCB}(87-61-6)$ & & \\
\hline Tricloroeteno & $79-01-6$ & $\mu \mathrm{g} / \mathrm{L}$ & 20 \\
\hline \multicolumn{4}{|c|}{ AGROTÓXICOS } \\
\hline $2,4 \mathrm{D}+2,4,5 \mathrm{~T}$ & $94-75-7(2,4$ D) 93-76-5 (2,4,5 T) & $\mu \mathrm{g} / \mathrm{L}$ & 30 \\
\hline Alaclor & $15972-60$ & $\mu \mathrm{q} / \mathrm{L}$ & 20 \\
\hline $\begin{array}{c}\text { Aldicarbe + Aldicarbesulfona + } \\
\text { Aldicarbesulfóxido }\end{array}$ & $\begin{array}{l}\text { 116-06-3 (aldicarbe) 1646-88-4 } \\
\text { (aldicarbesulfona) 1646-87-3 } \\
\text { (aldicarbe sulfóxido) }\end{array}$ & $\mu g / L$ & 10 \\
\hline Aldrin + Dieldrin & 309-00-2 (aldrin) 60-57-1 (dieldrin & $\mu \mathrm{g} / \mathrm{L}$ & 0,03 \\
\hline Atrazina & $1912-24-9$ & $\mu \mathrm{q} / \mathrm{L}$ & 2 \\
\hline Carbendazim + benomil & $10605-21-7$ & $\mu \mathrm{g} / \mathrm{L}$ & 120 \\
\hline Carbofurano & $1563-66-2$ & $\mu \mathrm{g} / \mathrm{L}$ & 7 \\
\hline
\end{tabular}




\begin{tabular}{|c|c|c|c|}
\hline Clordano & $5103-74-2$ & $\mu \mathrm{g} / \mathrm{L}$ & 0,2 \\
\hline Clorpirifós + clorpirifós-oxon & $\begin{array}{l}\text { 2921-88-2 (clorpirifós) 5598-15-2 } \\
\text { (clorpirifós-oxon) }\end{array}$ & $\mu g / L$ & 30 \\
\hline $\mathrm{DDT}+\mathrm{DDD}+\mathrm{DDE}$ & $\begin{array}{c}\text { p,p'-DDT (50-29-3) p,p'-DDD (72- } \\
54-8) \text { p,p'-DDE (72-55-9) }\end{array}$ & $\mu g / L$ & 1 \\
\hline Diuron & $330-54-1$ & $\mu \mathrm{g} / \mathrm{L}$ & 90 \\
\hline Endossulfan (a b e sais) (3) & $\frac{115-29-7 ; \text { I }(959-98-8) ; \text { II }}{\text { (33213-65-9); sulfato (1031-07-8) }}$ & $\mu \mathrm{g} / \mathrm{L}$ & 20 \\
\hline Endrin & $72-20-8$ & $\mu \mathrm{g} / \mathrm{L}$ & \\
\hline Glifosato + AMPA & $\begin{array}{l}\text { 1071-83-6 (glifosato) 1066-51-9 } \\
\text { (AMPA) }\end{array}$ & $\mu g / L$ & \\
\hline Lindano (gama HCH) (4) & $58-89-9$ & $\mu \mathrm{g} / \mathrm{L}$ & 2 \\
\hline Mancozebe & $8018-01-7$ & $\mu \mathrm{g} / \mathrm{L}$ & 180 \\
\hline Metamidofós & $10265-92-6$ & $\mu \mathrm{g} / \mathrm{L}$ & 12 \\
\hline Metolacloro & $51218-45-2$ & $\mu \mathrm{g} / \mathrm{L}$ & 10 \\
\hline Molinato & $2212-67-1$ & $\mu \mathrm{g} / \mathrm{L}$ & 6 \\
\hline Parationa Metílica & $298-00-0$ & $\mu \mathrm{g} / \mathrm{L}$ & 9 \\
\hline Pendimentalina & 40487-42-1 & $\mu \mathrm{g} / \mathrm{L}$ & 20 \\
\hline Permetrina & 52645-53-1 & $\mu \mathrm{g} / \mathrm{L}$ & 20 \\
\hline Profenofós & $41198-08-7$ & $\mu \mathrm{g} / \mathrm{L}$ & 60 \\
\hline Simazina & $122-34-9$ & $\mu \mathrm{g} / \mathrm{L}$ & 2 \\
\hline Tebuconazol & 107534-96-3 & $\mu \mathrm{g} / \mathrm{L}$ & 180 \\
\hline Terbufós & $13071-79-9$ & $\mu \mathrm{g} / \mathrm{L}$ & 1,2 \\
\hline Trifluralina & $1582-09-8$ & $\mu \mathrm{g} / \mathrm{L}$ & 8 \\
\hline \multicolumn{4}{|c|}{ DESINFETANTES E PRODUTOS SECUNDÁRIOS DA DESINFECÇÃO(5) } \\
\hline Ácidos haloacéticos total & $(6)$ & $\mathrm{mg} / \mathrm{L}$ & 0,08 \\
\hline Bromato & $15541-45-4$ & $\mathrm{mg} / \mathrm{L}$ & 0.01 \\
\hline Clorito & $7758-19-2$ & $\mathrm{mg} / \mathrm{L}$ & 1 \\
\hline Cloro residual livre & $7782-50-5$ & $\mathrm{mg} / \mathrm{L}$ & 5 \\
\hline Cloraminas Total & 10599-903 & $\mathrm{mg} / \mathrm{L}$ & 4,0 \\
\hline 2,4,6 Triclorofenol & $88-06-2$ & $\mathrm{mg} / \mathrm{L}$ & 0,2 \\
\hline Trihalometanos Total & (7) & $\mathrm{mg} / \mathrm{L}$ & 0,1 \\
\hline
\end{tabular}

Notas:

(1) CAS é o número de referência de compostos e substâncias químicas adotado pelo Chemical Abstract Service.

(2) Valor Máximo Permitido.

(3) Somatório dos isômeros alfa, beta e os sais de endossulfan, como exemplo o sulfato de endossulfan.

(4) Esse parâmetro é usualmente e equivocadamente, conhecido como BHC.

(5) Análise exigida de acordo com o desinfetante utilizado.

(6) Ácidos haloacéticos: Ácido monocloroacético (MCAA) - CAS = 79-11-8, Ácido monobromoacético (MBAA) -CAS = 79-08-3, Ácido dicloroacético (DCAA) - CAS = 79-43-6, Ácido 2,2 - dicloropropiônico (DALAPON) - CAS = 75-99- 0, Ácido tricloroacético (TCAA) - CAS = 76-03-9, Ácido bromocloroacético (BCAA) CAS = 5589-96-3, 1,2,3, tricloropropano (PI) - CAS = 96-18-4, Ácido dibromoacético (DBAA) - CAS = 631-64-1, e Ácido bromodicloroacético $(B D C A A)-C A S=7113-314-7$.

(7) Trihalometanos: Triclorometano ou Clorofórmio (TCM) - CAS $=67-66-3$, Bromodiclorometano $(\mathrm{BDCM})$ - CAS $=75-27-4$, Dibromoclorometano $(\mathrm{DBCM})$ - $\mathrm{CAS}=124-48-1$, Tribromometano ou Bromofórmio (TBM) - CAS = 75-25-2. 


\section{ANEXO 3}

Tabela 19 - Anexo 10 do Anexo XX: tabela de padrão organoléptico de potabilidade (origem: Portaria $\mathrm{MS} / \mathrm{GM} \mathrm{n}^{\circ}$ 2.914/2011, Anexo 10)

\begin{tabular}{|l|l|c|c|}
\hline \multicolumn{1}{|c|}{ Parâmetro } & \multicolumn{1}{c|}{ CAS } & Unidade & VMP(1) \\
\hline Alumínio & $7429-90-5$ & $\mathrm{mg} / \mathrm{L}$ & 0,2 \\
\hline Amônia & $7664-41-7$ & $\mathrm{mg} / \mathrm{L}$ & 1,5 \\
\hline Cloreto & $16887-00-6$ & $\mathrm{mg} / \mathrm{L}$ & 250 \\
\hline Cor Aparente (2) & & $\mathrm{uH}$ & 15 \\
\hline 1,2 diclorobenzeno & $95-50-1$ & $\mathrm{mg} / \mathrm{L}$ & 0,01 \\
\hline 1,4 diclorobenzeno & $106-46-7$ & $\mathrm{mg} / \mathrm{L}$ & 0,03 \\
\hline Dureza total & & $\mathrm{mg} / \mathrm{L}$ & 500 \\
\hline Etilbenzeno & $100-41-4$ & $\mathrm{mg} / \mathrm{L}$ & 0,2 \\
\hline Ferro & $7439-89-6$ & $\mathrm{mg} / \mathrm{L}$ & 0,3 \\
\hline Gosto e odor (3) & & $\mathrm{Intensidade}$ & 6 \\
\hline Manganês & $7439-96-5$ & $\mathrm{mg} / \mathrm{L}$ & 0,1 \\
\hline Monoclorobenzeno & $108-90-7$ & $\mathrm{mg} / \mathrm{L}$ & 0,12 \\
\hline Sódio & $7440-23-5$ & $\mathrm{mg} / \mathrm{L}$ & 200 \\
\hline Sólidos dissolvidos totais & & $\mathrm{mg} / \mathrm{L}$ & 1000 \\
\hline Sulfato & $14808-79-8$ & $\mathrm{mg} / \mathrm{L}$ & 250 \\
\hline Sulfeto de hidrogênio & $7783-06-4$ & $\mathrm{mg} / \mathrm{L}$ & 0,1 \\
\hline Surfactantes (como LAS) & & $\mathrm{mg} / \mathrm{L}$ & 0,5 \\
\hline Tolueno & $108-88-3$ & $\mathrm{mg} / \mathrm{L}$ & 0,17 \\
\hline Turbidez (4) & & $\mathrm{uT}$ & 5 \\
\hline Zinco & $7440-66-6$ & $\mathrm{mg} / \mathrm{L}$ & 5 \\
\hline Xilenos & $1330-20-7$ & $\mathrm{mg} / \mathrm{L}$ & 0,3 \\
\hline
\end{tabular}

Notas:

(1) Valor máximo permitido.

(2) Unidade Hazen (mgPt-Co/L).

(3) Intensidade máxima de percepção para qualquer característica de gosto e odor com exceção do cloro livre, nesse caso por ser uma característica desejável em água tratada.

(4) Unidade de turbidez. 


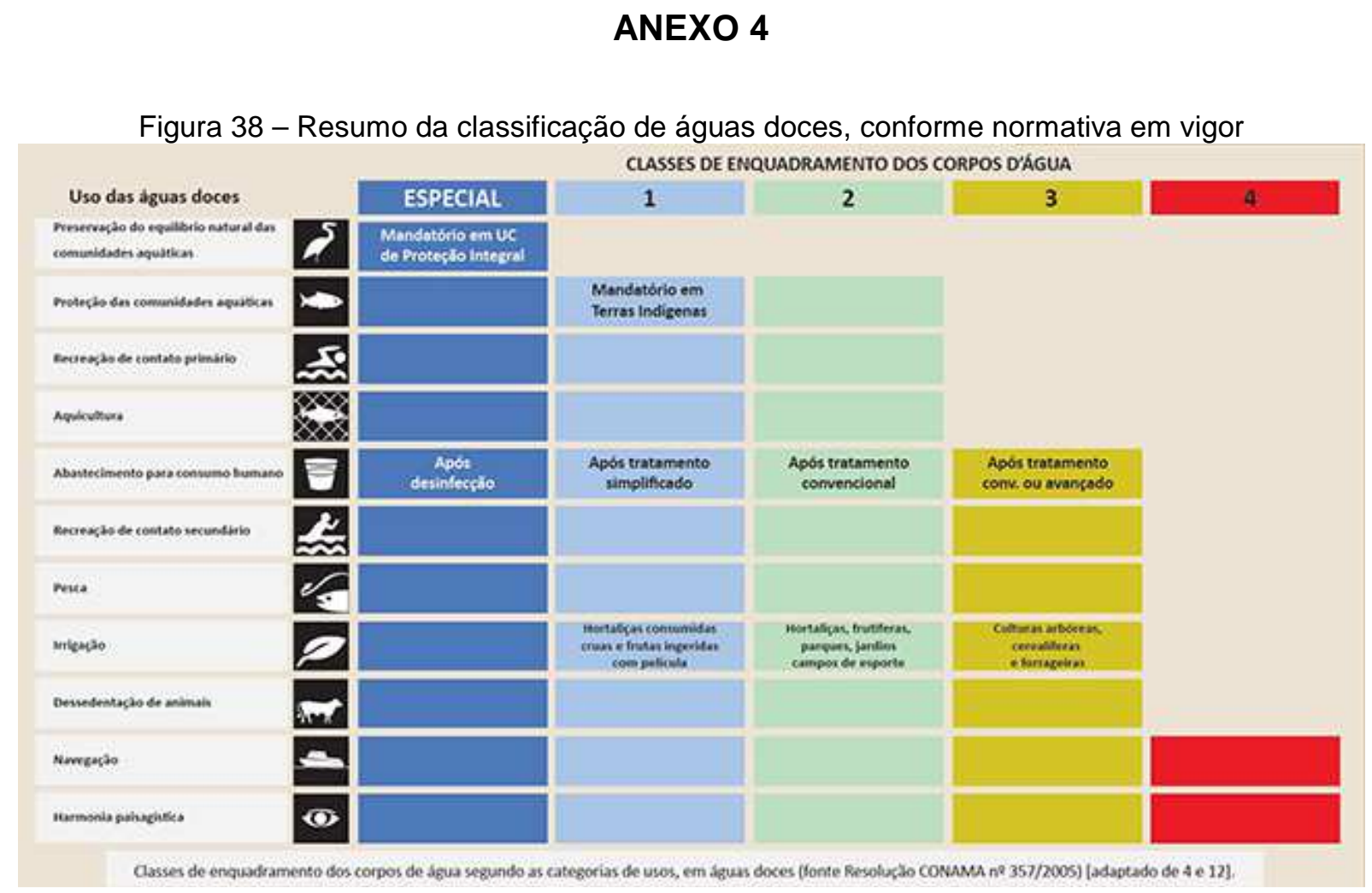

Fonte: São Paulo,2019b.

Conforme Resolução Conama ํo 35/2005 (BRASIL,2005), segue classificação:

CLASSE ESPECIAL, águas destinadas a(o):

- abastecimento para consumo humano, com desinfecção;

- preservação do equilíbrio natural das comunidades aquáticas;

- preservação dos ambientes aquáticos em unidades de conservação de proteção integral.

CLASSE 1 , águas que podem ser destinadas a(0):

- abastecimento para consumo humano, após tratamento simplificado;

- proteção das comunidades aquáticas;

- recreação de contato primário (natação, esqui aquático e mergulho), conforme CONAMA 274/2000;

- irrigação de hortaliças consumidas cruas e de frutas (rente ao solo) e que sejam ingeridas cruas sem remoção de película;

- proteção das comunidades aquáticas em terras Indígenas.

CLASSE 2, águas que podem ser destinadas a(0):

- abastecimento para consumo humano, após tratamento convencional; 
- proteção das comunidades aquáticas;

- à recreação de contato primário (natação, esqui aquático e mergulho), conforme CONAMA 274/2000;

- irrigação de hortaliças e plantas frutíferas, parque e jardins e outros com os quais o público possa vir a ter contato direto;

- aqüicultura e à atividade de pesca.

CLASSE 3, águas que podem ser destinadas a(0):

- abastecimento para consumo humano, após tratamento convencional ou avançado;

- irrigação de culturas arbóreas, cerealíferas e forrageiras;

- pesca amadora;

- recreação de contato secundário;

- dessedentação de animais.

CLASSE 4, águas que podem ser destinadas à:

- navegação;

- harmonia paisagística. 